DOE/RL-94-89

Revision 2

UC-630

\title{
State Waste Discharge Permit Application 400 Area Secondary Cooling Water
}

Date Published

January 1996

United States

Department of Energy

P.O. Box 550

Richland, Washington 99352

Approved for Public Release 
TRADEMARK DISCLAIMER

Reference herein to any specific commercial product, process, or service by trade name, trademark, manufacturer, or otherwise, does not necessarily constitute or imply its endorsement, recommendation, or favoring by the United States Government or any agency thereof or its contractors or subcontractors.

This report has been reproduced from the best available copy. Available in paper copy and microfiche.

Available to the U.S. Department of Energy and its contractors from

Office of Scientific and Technical Information

P.O. Box 62

Oak Ridge, TN 37831

(615) $576-8401$

Available to the public from the U.S. Department of Commerce National Technical information Service

5285 Port Royal Road

Springfield, VA 22161

(703) $487-4650$

Printed in the United States of America

DISCLM-5.CHP (8-91) 
DOE/RL-94-89, Rev. 2

$01 / 96$

\section{FOREWORD}

This document constitutes the Washington Administrative Code 173-216 State Waste Discharge Permit Application that serves as interim compliance as required by Consent, Order DE 91NM-177, for the 400 Area Secondary Cooling Water stream.

As part of the Hanford Federal Facility Agreement and Consent Order negotiations, the U.S. Department of Energy, Richland Operations office, the U.S. Environmental Protection Agency, and the Washington State Department of Ecology agreed that liquid effluent discharges to the ground on the Hanford Site that affect groundwater or have the potential to affect groundwater would be subject to permitting under the structure of Chapter 173-216 of the Washington Administrative Code, the State Waste Discharge Permitting Program. As a result of this decision, the Washington State Department of Ecology and the U.S. Department of Energy, Richland Operations Office entered in to Consent Order DE 91NM-177.

The Consent Order DE 91NM-177 requires a series of permitting activities for liquid effluent discharges. Based upon compositional and flow rate characteristics, liquid effluent streams on the Hanford Site have been categorized into Phase I, Phase II, and Miscellaneous streams. This document only addresses the 400 Area Secondary Cooling Water stream, which has been identified as a Phase II stream and is listed on Table 3 of the Consent Order DE $91 \mathrm{NM}-177$.

The 400 Area Secondary Cooling Water stream includes contributing streams from the Fuels and Materials Examination Facility, the Maintenance and Storage Facility, the 481-A Pump House, and the Fast Flux Test Facility. The effluent is discharge to the 4608 Percolation Ponds B and C.

With the changes in the Mission for the Fast Flux Testing Facility, Revision 2 updates the State Waste Discharge Permit Application for the 400 Area Secondary Cooling Water, originally submitted to the Washington State Department of Ecology in December 1992. 


\section{DOE/RL-94-89, Rev. 2}

$01 / 96$

This page intentionally left blank. 


\section{CONTENTS}

FOREWORD i i i

GLOSSARY

vii

PERMIT APPLICATION 1

ATTACHMENTS

A HANFORD SITE MAP ...................... ATT A-i

B* FACILITIES DESCRIPTIONS . . . . . . . . . . . . . ATT B-i

c* EFFLUENT STREAM DESCRIPTION . . . . . . . . . . . . . . . ATT c-i

D* MATERIALS STORED ONSITE . . . . . . . . . . . . . . . ATT D- $i$

E* COOLING WATER FLOWCHARTS ................... ATT E-

F STORMWATER DISPOSAL MAP . . . . . . . . . . . . . . . ATT F-

G 400 AREA TOPOGRAPHIC MAPS ............................. ATT G-i

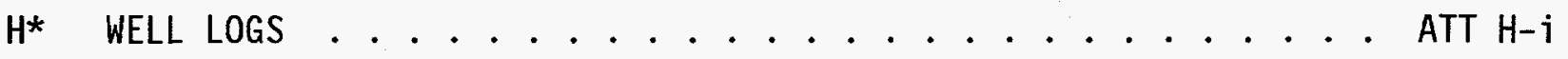

I GEOLOGY AND HYDROGEOLOGY OF THE 400 AREA . . . . . . . . . . . ATT I-i

J WASTEWATER INFORMATION . . . . . . . . . . . . . . . . ATT J-i

$K^{*}$ REFERENCES AND METRIC CONVERSION CHART . . . . . . . . . . . ATT K-i

* Revised. 


\section{FIGURES}

\section{ATTACHMENT B}

1400 Area Secondary Cooling Water Schematic Drawing . . . . . . ATT B-FI

\section{ATTACHMENT C}

1400 Area Secondary Cooling Water Schematic Drawing . . . . . . ATT C-F1

2 FFTF Secondary Cooling Water System .............. ATT C-F2

3 FFTF Secondary Cooling Water System . . . . . . . . . . ATT C-F3

4 Fuels and Materials Examination Facility--Plan View . . . . . ATT C-F4

$5 \quad$ Fuels and Materials Examination Facility Process Waste Water Systems . . . . . . . . . . . . . . . ATT C-F5

6 Maintenance and Storage Facility--Plan View . . . . . . . . ATT C-F6

7 481-A Pumphouse .. . . . . . . . . . . . . . ATT C-F7

\section{ATTACHMENT E}

1400 Area Water Balance Average Annual Daily Flow Rates.... . ATT E-Fl

2400 Area Water Balance Peak Daily Flow Rates....... . . . ATT E-F2

\section{TABLE}

ATTACHMENT $C$

1400 Area Secondary Cooling Water System Source Status . . . . . ATT C-T1 


\section{GLOSSARY}

\begin{tabular}{|c|c|}
\hline $\begin{array}{l}\text { CAPS } \\
\text { CFR } \\
\text { CT }\end{array}$ & $\begin{array}{l}\text { contaminated air processing system } \\
\text { Code of Federal Regulations } \\
\text { cold trap }\end{array}$ \\
\hline DOE & U.S. Department of Energy \\
\hline $\begin{array}{l}\text { FFTF } \\
\text { FMEE }\end{array}$ & $\begin{array}{l}\text { Fast Flux Test Facility } \\
\text { Fuels and Materials Examination Facility }\end{array}$ \\
\hline$H \& V$ & heating \& ventilation \\
\hline IDS & interim decay and storage \\
\hline LDCV & large diameter cleaning vessel \\
\hline MASF & Maintenance and Storage Facility \\
\hline $\begin{array}{l}\text { RCRA } \\
\operatorname{Rx}\end{array}$ & $\begin{array}{l}\text { Resource Conservation and Recovery Act of } 1976 \\
\text { reactor plant }\end{array}$ \\
\hline SWDP & state waste discharge permit \\
\hline USGS & United States Geological Survey \\
\hline WAC & Washington Administrative Code \\
\hline
\end{tabular}




\section{D0E/RL-94-89, Rev. 2 \\ $01 / 96$}

This page intentionally left blank. 
Date Application

Received

Date Application

Accepted

Temporary Permit Effective: Date
For Office Use Only

Date Foe

Paid.

Application/

Permit No.

Facility No.

Temporary Permit

Expiration Date

This application is for a waste discharge permit as required in accordance with provisions of Chapter 90.48 RCW and Chapter 173-216 WAC. Additional information may be required. Information previously submitted and applicable to this application should be referenced in the appropriate section.

\section{SECTION A. GENERAL INFORMATION}

1. Company Name:

2. Mailing Address:

3. Facility Address:
U.S. Department of Energy, Richland Operations Office P.0. Box 550 Street Richland, WA 99352

City/State Zip

400 Area - Hanford Site (Refer to Attachment A) Street

City/State

Zip

4. Person to contact who is familiar with the information contained in this application:

R. N. Krekel Name
Permits \& Compliance Assessment Title (509) $376-4264$

5. Check One:

X Existing Discharge

Proposed Discharge

Anticipated, date of discharge:

I certify under penalty of law that this document and all attachments were prepared under my direction or supervision in accordance with a system designed to assure that qualified personnel properly gather and evaluate the information submitted. Based on my inquiry of the person or persons who manage the system, or those persons directly responsible for gathering the information, the information submitted is, to the best of my knowledge and belief, true, accurate, and complete. I am aware that there are significant penalties for submitting false information, including the possibility of a fine and/or imprisonment for knowing violations.

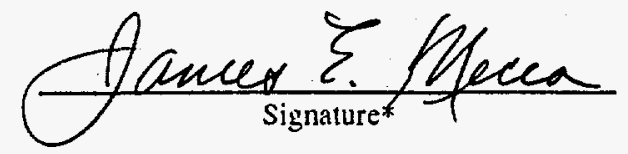

Seal if applicable
Manager, Transition Projects,

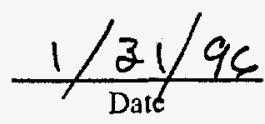
U.S. Department of Energy, Richland Operations office

\section{James E. Mecca}

Printed Name

*Applications must be signed by either the owner, the principal executive officer or a duly authorized representative. 


\section{SECTION B. PRODUCT OR SERVICE INFORMATION}

1.* Briefly describe all manufacturing processes and products, and/or service activities. Provide the applicable Standard Industrial Classification (SIC) Code(s) for each activity. SIC No(s): 9999

Description: Refer to Attachment B.

2.* Include a production schematic flow diagram of the process and service activities described above on a separate sheet.

Refer to Attachment B, Figure 1 .

3. List raw materials and products:

\begin{tabular}{||c|c|}
\hline \multicolumn{1}{|c|}{ Type } & QAW MATERIALS \\
\hline Not applicable & \\
\hline & \\
\hline & \\
\hline & \\
\hline & PRODUCTS \\
\hline & \\
\hline & \\
\hline & \\
\hline
\end{tabular}




\section{SECTION C. PLANT OPERATIONAL CHARACTERISTICS}

$1{ }^{*}$ Identify the waste stream for each of the production processes or activities described in Section B.1. Assign an identification number.

\begin{tabular}{||l|l|l|c||}
\hline \multicolumn{1}{|c|}{ Process } & \multicolumn{1}{|c|}{ Waste Stream Name } & \multicolumn{1}{|c|}{$\begin{array}{c}\text { Batch or } \\
\text { Continuous } \\
\text { Process }\end{array}$} & $\begin{array}{c}\text { Waste } \\
\text { Stream } \\
\text { ID \# }\end{array}$ \\
\hline FFTF Cooling Water & Cooling Water System & Continuous & 1 \\
\hline FMEF Cooling Water & Cooling Water System & Continuous & 2 \\
\hline $\begin{array}{l}\text { FFTF Containment H \& V } \\
\text { Condensate }\end{array}$ & $\begin{array}{l}\text { Moisture Condensate from } \\
\text { Ambient Air }\end{array}$ & Batch & 3 \\
\hline $\begin{array}{l}\text { FMEF Containment H \& V } \\
\text { Condensate }\end{array}$ & $\begin{array}{l}\text { Moisture Condensate from } \\
\text { Ambient Air }\end{array}$ & Batch & 4 \\
\hline Paint Shop Spray & $\begin{array}{l}\text { Filter Water from H \& V } \\
\text { Unit }\end{array}$ & Batch & 5 \\
\hline $\begin{array}{l}\text { MASF Large Diameter } \\
\text { Cleaning Vessel }\end{array}$ & $\begin{array}{l}\text { Pump Water for Testing of } \\
\text { Mitigation Pumps }\end{array}$ & Batch & 6 \\
\hline $\begin{array}{l}\text { MASF Bearing Cooling } \\
\text { Water }\end{array}$ & $\begin{array}{l}\text { Bearing Cooling Water } \\
\text { from Pump Test Runs }\end{array}$ & Batch & 7 \\
\hline $\begin{array}{l}\text { FMEF Retention Waste } \\
\text { System }\end{array}$ & System 36B & Batch & 8 \\
\hline FMEF Waste System & System 36D & Batch & 9 \\
\hline
\end{tabular}

2.* On a separate sheet, describe in detail the treatment and disposal of all wastewaters as described above. Include a schematic flow diagram for all wastewater treatment and disposal systems.

Refer to Attachment C.

3. Indicate treatment provided to each waste stream identified above.

No treatment provided.

\begin{tabular}{||l|l|l|l||}
\hline \hline Waste & \multicolumn{1}{|c|}{ Treatment } & Waste & \multicolumn{1}{|c|}{ Treatment } \\
\hline & Air flotation & & $\mathrm{pH}$ correction \\
\hline & Centrifuge & & Ozonation \\
\hline & Chemical precipitation & & Reverse osmosis \\
\hline & Chlorination & & Screen \\
\hline & Cyclone & & Sedimentation \\
\hline & Filtration & & Septic tank \\
\hline & Flow equalization & & Solvent separation \\
\hline & Grease or oil separation & & Bio. treatment, type: \\
\hline & Grease trap & & Rainwater diversion or storage \\
\hline & Grit removal & & Other chem. treatment, type: \\
\hline & Ion exchange & & Other phys. treatment, type: \\
\hline
\end{tabular}


4.* Describe any planned wastewater treatment improvements or changes in wastewater disposal methods:

Floor and equipment drains in MASF and FMEF have been plugged or diked (Refer to Attachment $C$, Table 1).

5.* If production processes are subject to seasonal variations, provide the following information. Write "Yes" for each month waste stream is produced.

\begin{tabular}{|c|c|c|c|c|c|c|c|c|c|c|c|c|}
\hline \multirow{2}{*}{$\begin{array}{c}\text { Waste } \\
\text { Stream } \\
\text { ID \# }\end{array}$} & \multicolumn{12}{|c|}{ MONTHS } \\
\hline & $J$ & $F$ & $M$ & A & $M$ & $J$ & $J$ & A & $S$ & 0 & $N$ & $\mathrm{D}$ \\
\hline 1 & Yes & Yes & Yes & Yes & Yes & Yes & Yes & Yes & Yes & Yes & Yes & Yes \\
\hline 2 & Yes & Yes & Yes & Yes & Yes & Yes & Yes & Yes & Yes & Yes & Yes & Yes \\
\hline & & & & & & & & & & & & \\
\hline & & & & & & & & & & & & \\
\hline & & & & & & & & & & & & \\
\hline & & & & & & & & & & & & \\
\hline & & & & & & & & & & & & \\
\hline & & & & & & & & & & & & \\
\hline & & & & & & & & & & & & \\
\hline
\end{tabular}

6.* Shift information:

a. Number of shifts per work day:

b. Number of work days per week:

c. Average number of work days per year:

d. Maximum number of work days per year:

e. Number of employees per shift:

1st
2nd
3rd

$\begin{array}{r}330 \\ \hline 18 \\ \hline 18 \\ \hline\end{array}$

1st
2nd
3rd

\begin{tabular}{c}
$\frac{3}{7}$ \\
\hline 365 \\
\hline 365 \\
\hline Shift start times
\end{tabular}

7.* List all incidental materials like oil, paint, grease, solvents, soaps, cleaners, that are used or stored on-site. (Use additional sheets, if necessary.)

Material/Quantity Stored

Refer to Attachment D. 
8.* Describe any water recycling or material reclaiming processes:

The water used in the cooling towers is recycled through the system 2.5 times or until the conductivity reading has reached 1,200 umhos. The chemical containers for the cooling tower treatment are rinsed out and the rinsate is added to the cooling tower sump.

The FFTF and FMEF recycle Tubricants offsite.

9. Does this facility have:

-Spill Control and Containment Plan (per 40 CFR 112)? $\quad \square$ Yes $\square$ No

-Emergency Response Plan (per WAC 173-303-350)? $\quad \square$ Yes $\square$ No

-Runoff, spillage, or leak control plan (per WAC 173-216-110(f))? $\quad$ X Yes $\square$ No

\section{SECTION D. WATER CONSUMPTION AND WATER LOSS}

1. Water source(s):

$\square$ Public System (Specify)

[ Private Well $\square$ Surface Water

a. Water Right Permit Number: Not applicable

b. Legal Description:

$\underline{\mathrm{NE}} 1 / 4 \mathrm{~S}, \underline{\mathrm{SW}} 1 / 4 \mathrm{~S}, \underline{18}$ Section, I1N TWN, 28E R

2.* andicate total water use: Gallons per day (average) 124,500

Gallons per day (maximum) 192,200

b. Is water metered? 团 Yes $\square$ No

3.* Attach a line drawing showing the water flow through the facility. Indicate source of intake water, operations contributing wastewater to the effluent, and treatment units labeled to correspond to the more detailed descriptions in Item C. Construct a water balance on the line drawing by showing average flows between intakes, operations, treatment units, and outfalls. If a water balance cannot be determined (e.g., for certain mining activities), provide a pictorial description of the nature and amount of any sources of water and any collection or treatment measures.

Refer to Attachment E. 


\section{SECTION E. WASTEWATER INFORMATION}

1. Provide measurements for the parameters listed below, unless waived by the permitting authority. All analytical methods used to meet these requirements shall, unless approved otherwise in writing by Ecology, conform to the Guidelines Establishing Test Procedures for the Analysis of Pollutants Contained in 40 CFR Part 136.

Note: Information is from sampling data collected from September 1992 through April 1995.

\begin{tabular}{|c|c|c|c|}
\hline Parameter/CAS No. & Concentrations Measured & Analytical Method & $\overline{\text { Detection Limit }}$ \\
\hline $\mathrm{pH}$ & 8.89 units & SW-846 & Not available \\
\hline Conductivity & 642 umhos & SW-846 & Not available \\
\hline Total Dissolved Solids & $509 \mathrm{mg} / \mathrm{L}$ & EPA 600160.1 & Not available \\
\hline Total Suspended & $8.5 \mathrm{mg} / \mathrm{L}$ & EPA 600160.2 & $5 \mathrm{mg} / \mathrm{L}$ \\
\hline BOD (5 day) & $17 \mathrm{mg} / \mathrm{L}$ & EPA 600 & $2 \mathrm{mg} / \mathrm{L}$ \\
\hline $\mathrm{COD}$ & $8 \mathrm{mg} / \mathrm{L}$ & EPA 600 & $5 \mathrm{mg} / \mathrm{L}$ \\
\hline Ammonia-N & Undetected & EPA 600 & $0.05 \mathrm{mg} / \mathrm{L}$ \\
\hline TKN-N & Not analyzed & & \\
\hline Nitrate-N & $0.2 \mathrm{mg} / \mathrm{L}$ & EPA 600 & Not available \\
\hline Ortho-phosphate-P & Not analyzed & & \\
\hline Total-phosphate-P & Undetected & EPA 600 & $0.25 \mathrm{mg} / \mathrm{L}$ \\
\hline Total Oil \& Grease & $5.4 \mathrm{mg} / \mathrm{L}$ & SW-846 & $5 \mathrm{mg} / \mathrm{L}$ \\
\hline Calcium $/ 7740-70-2$ & $61,933 \mu \mathrm{g} / \mathrm{L}$ & SW-846 & Not available \\
\hline Magnesium/7439-95-4 & $18,467 \mu \mathrm{g} / \mathrm{L}$ & SW-846 & Not available \\
\hline Sodium/7440-23-5 & $68,467 \mu \mathrm{g} / \mathrm{L}$ & SW-846 & Not available \\
\hline Potassium/7440-09-7 & $16,933 \mu \mathrm{g} / \mathrm{L}$ & SW-846 & Not available \\
\hline Chloride & $24,625 \mu \mathrm{g} / \mathrm{L}$ & EPA 600 & $1 \mathrm{mg} / \mathrm{L}$ \\
\hline Sulfate & $73,625 \mu \mathrm{g} / \mathrm{L}$ & EPA 600 & Not available \\
\hline Fluoride & $0.63 \mathrm{mg} / \mathrm{L}$ & EPA 600 & Not available \\
\hline Cadmium/7440-43-9 & $3.475 \mu \mathrm{g} / \mathrm{L}$ & SW-846 & Not available \\
\hline Chromium/7440-49-3 & $5.275 \mu \mathrm{g} / \mathrm{L}$ & SW-846 & Not available \\
\hline Lead/7439-92-1 & $3.8 \mu \mathrm{g} / \mathrm{L}$ & SW-846 & $2 \mu \mathrm{g} / \mathrm{L}$ \\
\hline Mercury/7439-97-6 & $0.1 \mu \mathrm{g} / \mathrm{L}$ & SW-846 & $0.1 \mu \mathrm{g} / \mathrm{L}$ \\
\hline Selenium/7782-49-2 & $9.7 \mu \mathrm{g} / \mathrm{L}$ & SW-846 & $2 \mu \mathrm{g} / \mathrm{L}$ \\
\hline Silver/7440-22-4 & $5.9 \mu \mathrm{g} / \mathrm{L}$ & SW-846 & Not available \\
\hline Copper/7440-50-8 & $9.2 \mu \mathrm{g} / \mathrm{L}$ & SW-846 & Not available \\
\hline Iron/7439-89-6 & $39.6 \mu \mathrm{g} / \mathrm{L}$ & SW-846 & Not available \\
\hline Manganese & $44.6 \mu \mathrm{g} / \mathrm{L}$ & SW-846 & Not available \\
\hline Zinc/7440-66-6 & $55.7 \mu \mathrm{g} / \mathrm{L}$ & SW-846 & Not available \\
\hline Barium/7440-39-3 & $36.8 \mu \mathrm{g} / \mathrm{L}$ & SW-846 & Not available \\
\hline Total Coliform & $543 \mathrm{TCOL}$ & SM 9221 & $1 \mathrm{TCOL}$ \\
\hline
\end{tabular}


2.* Wastewater characteristics for toxic pollutants.

The intent of this question is to determine which chemicals are or might be present in the process water or wastewater. For each chemical listed below:

a. Use the letter $\mathbf{A}$ in the ABST column if the chemical is not likely to be present because it is not used in the production process or used on site.

b. Use the letter $\mathbf{S}$ in the ABST column if the chemical may be present because it is used on site, but the chemical is not used in the production process.

c. Use the letter $\mathbf{P}$ in the PRST column if the chemical is likely to be present because it is used in the production process, but the effluent has not been tested.

d. Use the letter $\mathbf{K}$ in the PRST column if the effluent has been tested and found to be present.

Attach the analytical results. Submit to Ecology in March 1995

Analytical Results

Wastewater Characterization for Toxic Pollutants

\begin{tabular}{|c|c|c|c|}
\hline ABST / PRST & CONSTITUENT/CAS No. & ABST / PRST & CONSTITUENT/CAS No. \\
\hline A & Acrylamide/79-06-1 & A & 1,2 Dichloropropane/78-87-5 \\
\hline A & Acrylonitrile/107-13-1 & A & 1,3 Dichloropropene/542-75-6 \\
\hline A & Aldrin/309-00-2 & A & Dichlorvos/62-73-7 \\
\hline A & Aniline/62-53-3 & A & Dieldrin/60-57-1 \\
\hline A & Aramite/140-57-8 & A & 3,3' Dimethoxybenzidine/119-90-4 \\
\hline A & Arsenic/7440-38-2 & A & 3,3 Dimethylbenzidine/119-93-7 \\
\hline A & Azobenzene/103-33-3 & A & 1,2 Dimethylhydrazine/540-73-8 \\
\hline A & Benzene/71-43-2 & A & 2,4 Dinitrotoluene/121-14-2 \\
\hline A & Benzidine/92-87-5 & A & 2,6 Dinitrotoluene/606-20-2 \\
\hline A & Benzola)pyrene/50-32-8 & A & 1,4 Dioxane/123-91-1 \\
\hline A & Benzotrichloride/98-07-7 & A & 1,2 Diphenylhydrazine/122-66-7 \\
\hline A & Benzyl chloride/100-44-7 & A & Endrin/72-20-8 \\
\hline A & Bis(chloroethyl)ether/111-44-4 & A & Epichlorohydrin/106-89-8 \\
\hline A & Bis(chloromethyl)ether/542-88-1 & A & Ethyl acrylate/140-88-5 \\
\hline A & $\begin{array}{l}\text { Bis(2-ethylhexyl)phthalate/ } \\
117-81-7\end{array}$ & A & Ethylene dibromide/106-93-4 \\
\hline A & Bromodichloromethane/75-27-4 & A & Ethylene thioureae/96-45-7 \\
\hline A & Bromoform/75-25-2 & A & Folpet/133-07-3 \\
\hline A & Carbazole/86-74-8 & A & Furmecyclox/60568-05-0 \\
\hline
\end{tabular}




\begin{tabular}{|c|c|c|c|}
\hline ABST / PRST & CONSTITUENT/CAS No. & ABST / PRST & CONSTITUENT/CAS No. \\
\hline A & Carbon tetrachloride/56-23-5 & A & Heptachlor/76-44-8 \\
\hline A & Chlordane/57-74-9 & A & Heptachlor epoxide/1024-57-3 \\
\hline A & Chlorodibromomethane/124-48-1 & A & Hexachlorobenzene/118-74-1 \\
\hline$A$ & Chloroform/67-66-3 & A & $\begin{array}{l}\text { Hexachlorocyclohexane (alpha)/ } \\
319-84-6\end{array}$ \\
\hline A & Chlorthalonil/1 897-45-6 & A & $\begin{array}{l}\text { Hexachlorocyclohexane (tech.)/ } \\
608-73-1\end{array}$ \\
\hline A & 2,4-D/94-75-7 & A & $\begin{array}{l}\text { Hexachlorodibenzo-p-dioxin, mix/ } \\
19408-74-3\end{array}$ \\
\hline A & DDT/50-29-3 & $A$ & $\begin{array}{l}\text { Hydrazine/hydrazine sulfate/ } \\
302-01-2\end{array}$ \\
\hline A & Diallate/2303-16-4 & A & Lindane/58-89-9 \\
\hline A & 1,2 Dibromoethane/106-93-4 & A & 2 Methylaniline/100-61-8 \\
\hline A & 1,4 Dichlorobenzene/106-46-7 & A & $\begin{array}{l}2 \text { Methylaniline hydrochloride/ } \\
636-21-5\end{array}$ \\
\hline A & 3,3' Dichlorobenzidine/91-94-1 & A & $\begin{array}{l}4,4^{\prime} \text { Methylene bis }(\mathrm{N}, \mathrm{N}- \\
\text { dimethyl)aniline/101-61-1 }\end{array}$ \\
\hline A & 1,1 Dichloroethane/75-34-3 & A & $\begin{array}{l}\text { Methylene chloride } \\
\text { (dichloromethane)/75-09-2 }\end{array}$ \\
\hline A & 1,2 Dichloroethane/107-06-2 & $A$ & Mirex/2385-85-5 \\
\hline A & Nitrofurazone/59-87-0 & A & O-phenylenediamine/106-50-3 \\
\hline A & $\begin{array}{l}\text { N-nitrosodiethanolamine/ } \\
1116-54-7\end{array}$ & A & Propylene oxide/75-56-9 \\
\hline A & $\mathrm{N}$-nitrosodiethylamine/55-18-5 & $A$ & $\begin{array}{l}\text { 2,3,7,8-Tetrachlorodibenzo-p-dioxin/ } \\
1746-01-6\end{array}$ \\
\hline$A$ & N-nitrosodimethylamine/62-75-9 & $A$ & Tetrachloroethylene/127-18-4 \\
\hline$A$ & N-nitrosodiphenylamine/86-30-6 & A & 2,4 Toluenediamine/95-80-7 \\
\hline A & $\begin{array}{l}\text { N-nitroso-di-n-propylamine/ } \\
621-64-7\end{array}$ & A & o-Toluidine/95-53-4 \\
\hline A & $\mathrm{N}$-nitrosopyrrolidine/930-55-2 & A & Toxaphene/8001-35-2 \\
\hline A & $\begin{array}{l}\text { N-nitroso-di-n-butylamine/ } \\
924-16-3\end{array}$ & A & Trichloroethylene/79-01-6 \\
\hline A & $\begin{array}{l}\text { N-nitroso-n-methylethylamine/ } \\
10595-95-6\end{array}$ & $A$ & 2,4,6-Trichlorophenol/88-06-2 \\
\hline A & $\mathrm{PAH} / \mathrm{NA}$ & A & Trimethyl phosphate/512-56-1 \\
\hline A & PBBs/NA & A & Vinyl chloride/75-01-4 \\
\hline$S$ & PCBs/1336-36-3 & & \\
\hline
\end{tabular}




\section{SECTION F. STORMWATER}

1. Do you have a stormwater NPDES permit?

Yes \ No

2. Have you applied for a stormwater NPDES permit?

$\square$ Yes $\mathbb{D}$ No

3. Are you covered or have you applied for coverage

X Yes

No under a general or group stormwater permit?

4. Describe the size of the stormwater collection area.
a. Unpaved Area
$5,840,000$ sq. ft.
b. Paved Area
c. Other Collection Areas (Roofs)
975,000 sq. ft.
753,000 sq. $\mathrm{ft}$.

5. Describe the stormwater management systems.

Stormwater is disposed to the ground via roof drain downcomers and dry wells. There is no sheet flow that comes out of the 400 Area.

6. Attach a map showing stormwater drainage/collection areas, disposal areas and discharge points.

Refer to Attachment F. 


\section{SECTION G. OTHER INFORMATION}

1. Describe liquid wastes or sludges being generated that are not disposed of in the waste stream(s).

Waste Tubricant oil

Low-level radioactive waste.

2. Describe storage areas for raw materials, products, and wastes.

The radioactive liquid waste is discharged to below grade 5,000 gallon tanks that are contained within buildings in concrete cells. When the tanks are full, the liquid waste is transferred to the Double-Shell Tank System.

3. Have you designated your wastes according to the procedures $\square \quad$ Yes $\square$ No of Dangerous Waste Regulations, Chapter 173-303 WAC?

4. Waste hauled off-site by: $\square$ Wastehauler; $\square]$ Self; $\square$ Other (identify)

\begin{tabular}{l} 
Name \\
\hline Address \\
\hline City/State \\
Telephone
\end{tabular}

\begin{tabular}{l} 
Name \\
\hline Address \\
$\overline{\text { City/State }}$ \\
\hline Telephone
\end{tabular}

5. Have you filed a SARA Title 313 Disclosure?

奵 Yes $\square$ No 


\section{SECTION H. SITE ASSESSMENT}

1. Give the legal description of the land treatment site(s). Give the acreage of each land treatment site(s). Attach a copy of the contract(s) authorizing use of land for treatment. NW 1/4, SW $1 / 4$, Sec. 18, T11N, R28F (46-26' - 23 9" latitude, $11921^{\prime} 231^{\prime \prime}$ 1ongitude) 0.23 acres $(10,000$ square feet).

2.* List all environmental control permits or approvals needed for this project; for example, septic tank permits, sludge application permits, or air emissions permits.

Hanford Site Radioactive Air Emissions Permit FF-01.

400 Area Sanitary Sewer System Wastewater Discharge Permit Application (DOE/RL-94-28).

400 Area Secondary Cooling Water Wastewater Discharge Permit Application (D0E/RL-94-89).

Registration of Hanford Site Class V Underground Injection We11s.

3. Attach a topographic map with contour intervals used by USGS. Show the following on this map:

Refer to Attachment G.,

a. Location and name of internal and adjacent streets

b. Surface water drainage systems

c. Water supply and other wells within 500 feet of the site

d. Surface water diversions within 500 feet of the site

e. Chemical and product handling and storage facilities

f. Infiltration sources, such as drainfields, lagoons, dry wells, and abandoned wells within 500 feet of the site

g. Wastewater and cooling water discharge points with ID numbers (See Section C.1)

h. Other activities and land uses within $1 / 4$ mile of the site

4.* Identify all wells within 500 feet of the site. Attach well logs when available and any available water quality data.

500 feet from percolation ponds: Well 699-2-7.

Farther than 500 feet from percolation ponds:

Wel1 499-S1-8J. Wel1 699-S6-E4E

Well 699-2-3 Wel1 699-S6-E4F

Well 699-S6-E4A Well 699-S6-E4G

Wel1 699-S6-E4B We11 699-S6-E4H

We11 699-S6-E4C We11 699-S6-E4J

Wel1 699-S6-E4D

5. Describe soils on the site using information from local soil survey reports.

(Submit on separate sheet.)

Refer to Attachment I. 
6. Describe the regional geology and hydrogeology within one mile of the site. (Submit on separate sheet.)

Refer to Attachment I.

7. List the names and addresses of contractors or consultants who provided information and cite sources of information by title and author.

Refer to Attachment $K$. 
D0E/RL-94-89, Rev. 2

ATTACHMENT A

HANFORD SITE MAP 
DOE/RL-94-89, Rev. 2 $01 / 96$

This page intentionally left blank. 


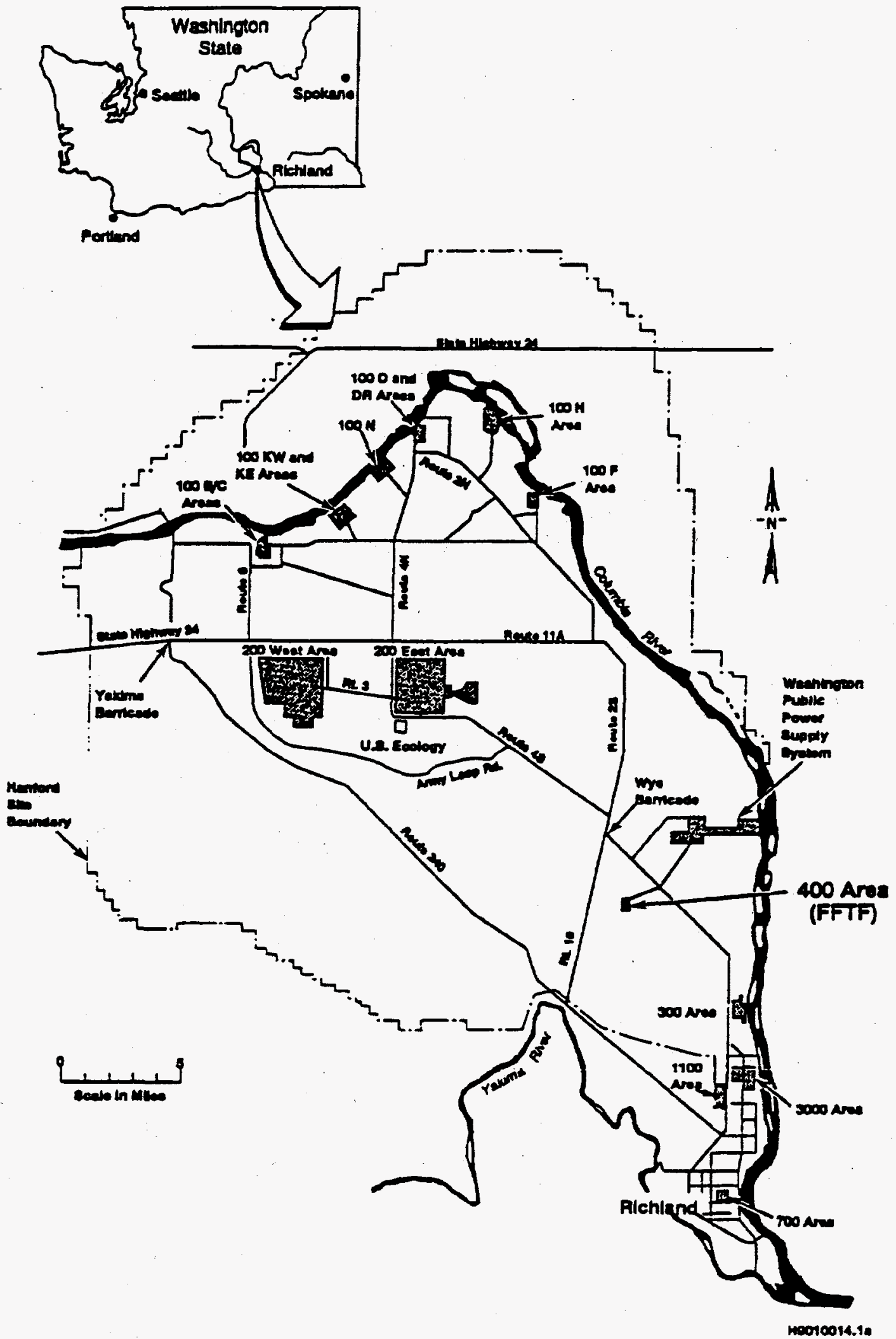

Hanford Site Map with 400 Area Location. 
•

-

- 


\section{ATTACHMENT B}

FACILITIES DESCRIPTIONS

(SECTION B - ITEM 1) 
DOE/RL-94-89, Rev. 2
$01 / 96$

This page intentionally left blank. 


\title{
ATTACHMENT B
}

\author{
FACILITIES DESCRIPTIONS \\ (SECTION B - ITEM 1)
}

The 400 Area contains the Fast Flux Test Facility (FFTF), the Fuels and Materials Examination Facility (FMEF), the Maintenance and Storage Facility (MASF), and a number of buildings that supported FFTF operations (Figure 1). There are four facilities in the 400 Area that contribute to the 400 Area

Secondary Cooling Water (400 Area Process Sewer). These four contributors are described as follows.

\section{FAST FLUX TEST FACILITY}

The FFTF is a sodium-cooled test reactor that was used for nuclear research. The reactor's high neutron flux level and neutron energies allowed accelerated testing of fuels and materials. The reactor operated from 1980 to Apri1 1, 1990, when it was ordered into standby status by the U.S. Department of Energy (DOE). In a December 15, 1993-memorandum, the DOE directed its Richland Operations office to initiate action to place the FFTF in a radiologically and industrially safe shutdown condition.

The processes that contribute to the 400 Area Process Sewer are the auxiliary system cooling towers and a batch discharge (described in Attachment $\mathrm{C}$ ). The cooling towers reduce the heat generated in the equipment supporting the FFTF auxiliary systems. There is no contact between the piping of the cooling towers and any radioactive liquid, waste, or nuclear materials in the reactor.

Adjacent to the cooling tower pad is a building containing water treatment equipment, water quality monitoring instrumentation, and process control for blowdown valves associated with the cooling towers. This system is adjacent to the reactor containment and service buildings within the 400 Area Property Protection Area.

\section{FUELS AND MATERIALS EXAMINATION FACILITY}

The FMEF was designed and constructed as a secure, multistoried structure with the capability of handling low and high exposure radioactive materials. Because of program and funding changes, most of the specialized equipment was never installed and radioactive material has never been introduced into the FMEF. The FMEF currently is used for administrative offices.

The processes that contribute to the 400 Area Process Sewer are the auxiliary systems cooling towers and batch discharges from the $36 \mathrm{~B}$ system and the $36 \mathrm{D}$ system. The $36 \mathrm{D}$ system originally was intended for radioactive waste, but with the change in mission for the FMEF, the $36 \mathrm{~B}$ system has never been used for holding radioactive waste. 
Engineering documents have been formally changed to reflect the correct status of the 360 system. The cooling system at the FMEF also is a non-contact cooling water system similar to the unit for the FFTF. A detailed description is contained in Attachment $C$.

\section{MAINTENANCE AND STORAGE FACILITY}

The MASF, located in the 400 Area Property Protection Area, consists of a main building and a two-story service wing. The purpose of MASF is to provide maintenance, repair, and storage areas for radioactive and/or specialized maintenance equipment used in support of the FFTF or other onsite activities.

The contributors to the 400 Area Process Sewer are floor and equipment drains located in the bay area. Batch discharges from the large diameter cleaning vessel (LDCV) and bearing cooling water from mitigation pump test runs also are discharged to the process sewer. Refer to Attachment $C$ for a detailed description.

\section{481-A WATER PUMPHOUSE}

The 481-A Water Pumphouse was constructed to provide space for a diesel driven fire pump and two sanitary water pumps. An equipment drain associated with sanitary water pump packing leakage contributes to the 400 Area Secondary Cooling Water. Refer to Attachment C for a detailed description. 
DOE/RL-94-89, Rev. 2

$01 / 96$

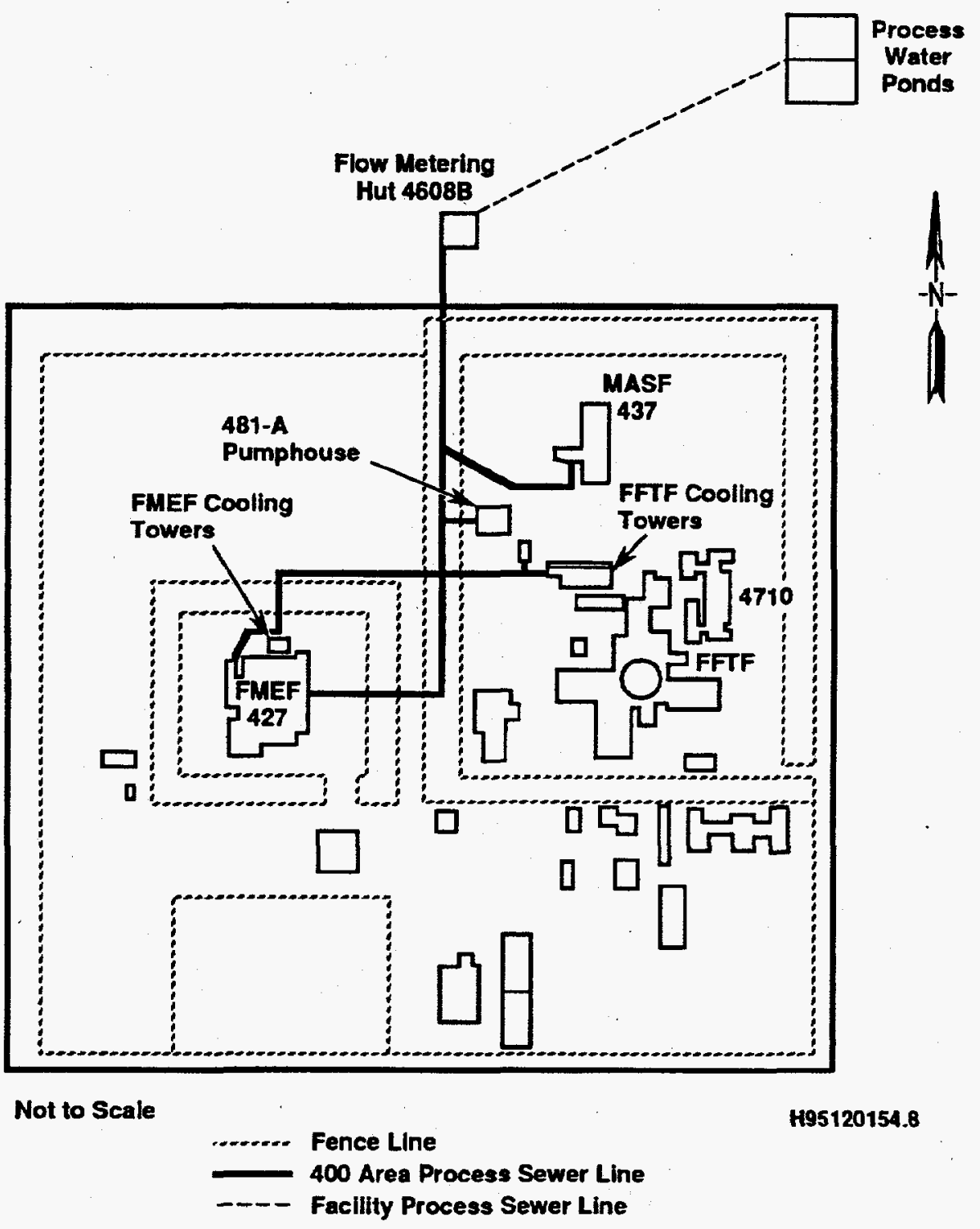

Figure 1. 400 Area Secondary Cooling Water Schematic Drawing. 
○

O

0 
D0E/RL-94-89, Rev. 2

$01 / 96$

ATTACHMENT C

EFFLUENT STREAM DESCRIPTION

(SECTION B - ITEM 1) 
DOE/RL-94-89, Rev. 2

This page intentionally left blank. 


\section{ATTACHMENT C}

\section{EFFLUENT STREAM DESCRIPTION (SECTION B - ITEM 1)}

The 400 Area Process Sewer discharge is composed of cooling water from FFTF and FMEF cooling towers (85 percent) and discharge from equipment, floor drains, and auxiliary cooling systems from the FFTF, FMEF, MASF, and the 481-A Pumphouse (15 percent). Of the 74 entry points documented (WHC 1992b), 33 floor drains either have been plugged permanently, bermed to prevent spills from entering the process sewer, or have a removable plug that requires certain procedures be completed before removal of the plug (refer to Table 1).

The 400 Area Process Sewer consists of a 12-inch main pipe, located approximately in the center of the 400 Area. Five 6-inch pipes discharge process water from the four facilities into the main pipe; two pipes from the FMEF and one pipe each from the other three facilities. The main pipe discharges to the 400 Area percolation ponds, which are located approximately 610 meters northeast of the northern fence line of the 400 Area (Figure 1).

The sampling location for the process sewer is contained in the flow metering hut (4608B) located just north of the northern fence line.

The following is a detailed description of the discharge from each facility.

1. Fast Flux Test Facility

The FFTF has one continuous discharge from the cooling towers, which is non-contact cooling water, and one batch discharge, which is condensate from the heating and ventilation (H\&V) units. The cooling tower continuous stream is composed of tower sump blowdown (for conductivity control) and sump overflow.

The cooling towers provide cooling to the Cooling Water System, which in turn provides cooling to the following various auxiliary systems:

- Incontainment chi11 water system

- Excontainment chill water system

- Radioactive argon processing system and contaminated air processing system

- Mobiltherm* cooling system

- Liquid rheostat cooling system.

* Mobiltherm is not a trademark. 
These auxiliary cooling systems cool systems that directly support operation of the reactor plant $\left(R_{x}\right)$ and the interim decay and storage (IDS) vessel and are explained in greater detail in the following. The letters for each system correspond to the letters in Figures 2 and 3.

A. A portion of the sodium contained in the reactor vessel is routed to a cold trap (CT), through the reactor overflow line (part of the reactor sodium level control system), for removal of impurities. The CT is cooled by a sodium potassium eutectic metal (NaK) system that, in turn, is cooled by an oil system containing Mobil thermolite oil. The Mobiltherm cooling system is cooled by the Cooling Water System.

The Mobiltherm cooling system has been drained of $0 i 1$ and the $0 i 1$ has been removed from the site. Cooling water is blocked from the Mobiltherm/cooling water heat exchanger by closed valves. This portion of the cooling water system is no longer active.

$B / C$. The reactor is cooled by three liquid sodium loops with each loop consisting of a primary and a secondary loop. Each primary and secondary loop contains a main circulating pump to provide motive force for the liquid sodium coolant. Each pump has a liquid rheostat in series with the field windings to control the speed of the pump. The liquid rheostat contains sodium carbonate $(3,407$ liters $)$ in a 2 to 3 percent weight solution. Because of the heat generated in the rheostat, the sodium carbonate solution must be cooled. Cooling water is supplied to a liquid rheostat/cooling water heat exchanger (one per rheostat) to remove the heat generated during operation. The rheostats are located in air atmosphere cells in the heat transport buildings of FFTF. The rheostats do not come into contact with any form of radioactive contamination or field.

D. The IDS vessel contains liquid sodium that is circulated to remove the decay heat from expended fuel elements stored in the vessel. The sodium loop is cooled by an NaK loop, which in turn is cooled by a Mobiltherm cooling system.

The Mobiltherm cooling system has been drained of $0 i 1$ and the $0 i 1$ has been removed from the site. Cooling water is blocked from the Mobiltherm/cooling water heat exchanger by closed valves. This portion of the cooling water system is no longer active.

E. The radioactive argon processing system (RAPS) processes radioactive argon used as a cover gas for the reactor. The contaminated air processing system (CAPS) processes the inert gas $\left(\mathrm{N}_{2}\right)$ used in cells that contained primary system sodium. The RAPS and CAPS compressors are cooled by the RAPS and CAPS cooling water system. This system removes the heat of compression and motor heat from the compressors. The RAPS and CAPS cooling water system is cooled by the cooling Water System through the RAPS and CAPS/c007ing water heat exchanger. 
The RAPS and CAPS cooling water system has been shutdown; although the system still contains the ethylene glycol/water solution.

F. The inert cells containing primary sodium coolant are cooled by inert gas blowers. The blowers take a suction on the inert cells and discharge the gas through a heat exchanger and return the gas to the cell. Incontainment chill water cools the inert gas blowers, using an ethylene glycol solution. The chill water is 'chilled' by use of Freon cycle chillers. The chillers are cooled by the cooling water system.

G. The cells outside of containment are cooled by various H\&V units. The H\&V units are cooled by excontainment chill water using an ethyléne glycol solution. The chill water is 'chilled' by use of Freon cycle chillers. The chillers are cooled by the cooling water system.

All the cooling water systems $(A-G)$ contain a 40 percent solution of ethylene glycol that is routed to the cooling towers (Figure 3 ). The cooling towers are galvanized steel, closed-loop evaporation cooling towers that circulate the ethylene glycol solution from the building through cooling coils in the cooling towers. Water is sprayed over the coils as air is blown up through the cooling towers by fans. The evaporation of the spray water provides the cooling effect, which is transferred through the cooling coils to the recirculated ethylene glycol solution. The eight cooling towers each have a sump capacity of 7,570 liters.

The water in the cooling tower sumps is treated chemically with a biocide (Dearborn 702)*, a microbiocide (sodium hypochlorite), and a scale inhibitor (Dearborn 878). Scale formation is created by the increasing concentration of naturaliy occurring salts (typically calcium carbonate) resulting from the evaporation process of the cooling towers. The electrical conductivity of the water in the sumps is monitored and when the conductivity approaches 1,200 micromhos, automatic valves open to discharge water. This allows the addition of fresh water to lower the conductivity to approximately 900 micromhos.

2. Fuel and Materials Examination Facility

The FMEF has four routine contributors, three discharges from the FMEF cooling towers and one from the pressure relief valve drain in the process water supply system in the mechanical equipment room (Figure 4).

In addition to the four routine contributors, there are two infrequent contributors, the 36B system and the 36D system. In the revision 0 application, the 36B system was labeled the Liquid Retention Waste system. The 36D system originally was intended to contain radioactive waste. However, with the change in mission for the FMEF, this system has

* Dearborn is trademark of W. R. Grace and Co., Lake Zurich, Illinois. 
not been used for its intended purpose. Waste water from the fire testing system and a lunchroom sink are the only discharges to the 360 system.

Both systems contain two 22,712 1iter tanks; the $36 \mathrm{~B}$ system tanks are fiberglass and the 36D system tanks are stainless steel. Figure 5 illustrates both systems including the overflow system and the recirculating 1 ines. The $36 \mathrm{~B}$ system can discharge to either the process sewer or the $36 \mathrm{D}$ system. A computer automatically shifts valves to the other tank when one tank is full. At this time, a technician secures a sample from the full tank and the sample is analyzed as required in the sampling and analysis plan (WHC 1995). With approval of the analysis results, 12,113 liters (maximum of the pumping system) are discharged to the process sewer.

The 36D system operates similar to the 36B system except the contents only can be sent to the liquid waste loadout room. Presently, a fire hose is connected to the line in the liquid waste loadout room and the contents are sent to the barrel washer pad, which is connected to the process sewer (Figure 4). Each system would discharge no more than once every 3 months.

The three cooling towers at the FMEF are identical to the cooling towers located at the FFTF and are operated under the same conditions. The same Dearborn chemicals are added to the water in the FFTF and FMEF cooling towers.

\section{Maintenance and Storage Facility}

The MASF has one routine contributor to the process sewer from the process equipment room air compressor. Two infrequent contributors are from the LDCV and bearing cooling water from mitigation pump test runs (Figure 6). These vessels currently are being used for the testing of new pumps. Water is added to the LDCV and discharged from the vessel to control the heat generated by the pumps. Testing occurs on an irregular basis, but no more frequently than once per month.

The discharge to the Process Sewer is monitored for radioactive contamination by an online monitor. Should radiation be detected, a diversion valve opens to discharge the process sewer water into the MASF radioactive waste system. The Process Sewer is protected from crosscontamination by a check valve downstream of the diversion valve and by piping elevation differences. The radioactive liquid waste system is a gravity drain system located about 1.22 meters below the process sewer.

\section{481-A Pumphouse}

The 481-A Pumphouse. (Figure 7) has one routine contributor associated with water pump packing leakage from the sanitary water pumps. The other drains have moats around the drains to prevent accidental discharge. 


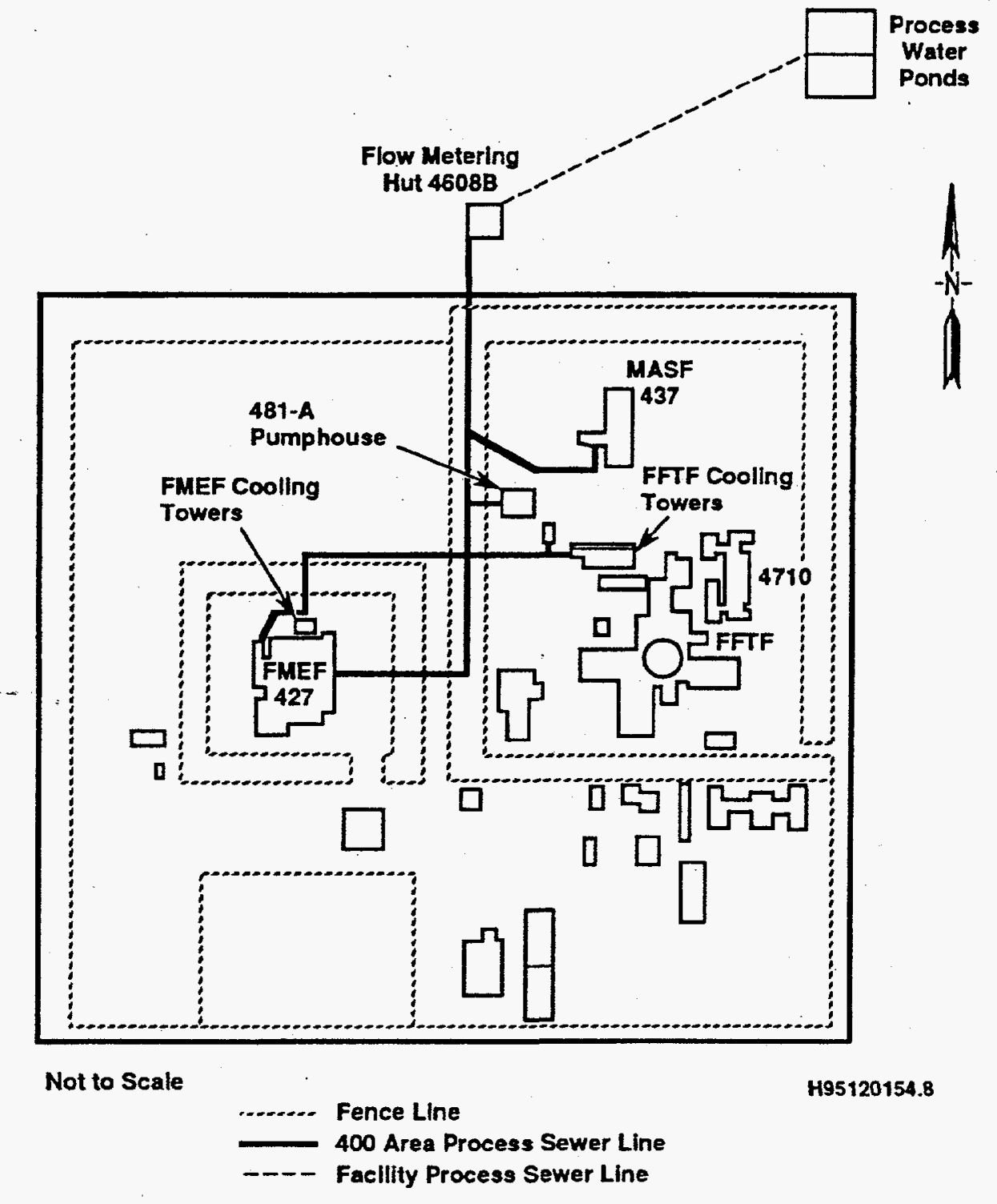

Figure 1. 400 Area Secondary Cooling Water Schematic Drawing. 
-

•

• 


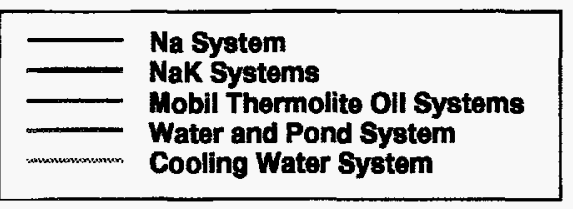

Cooling Water System
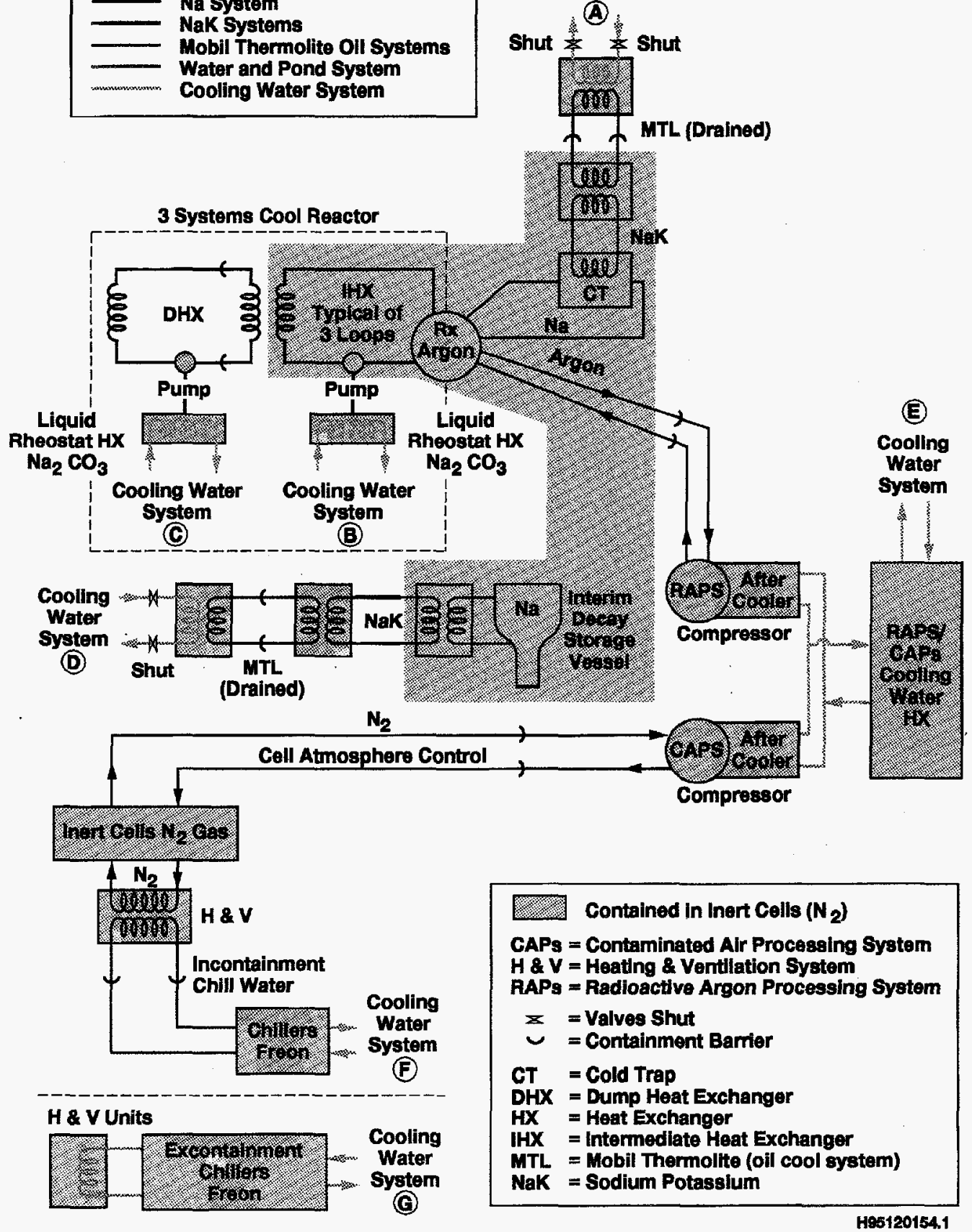

Figure 2. FFTF Secondary Cooling Water System. 
-

-

- 


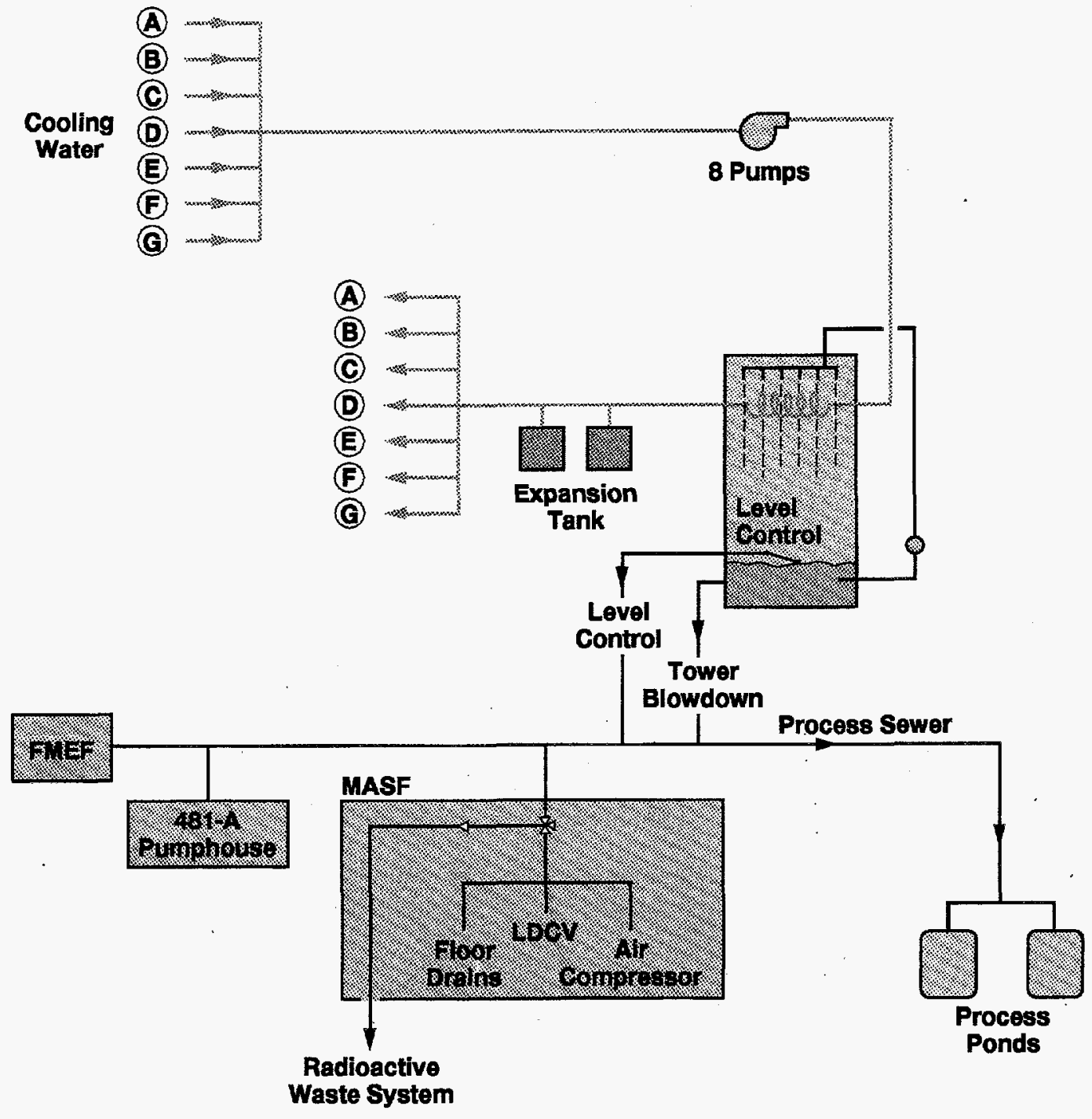

$$
\begin{aligned}
& \text { FMEF = Fuel and Materials Examination Facillity } \\
& \text { LDCV }=\text { Large Diameter Cleaning Vessel } \\
& \text { MASF = Maintenance and Storage Facillty }
\end{aligned}
$$

H95120154.2

Figure 3. FFTF Secondary Cooling Water System. 
-

-

- 
DOE/RL-94-89, Rev. 2

$01 / 96$
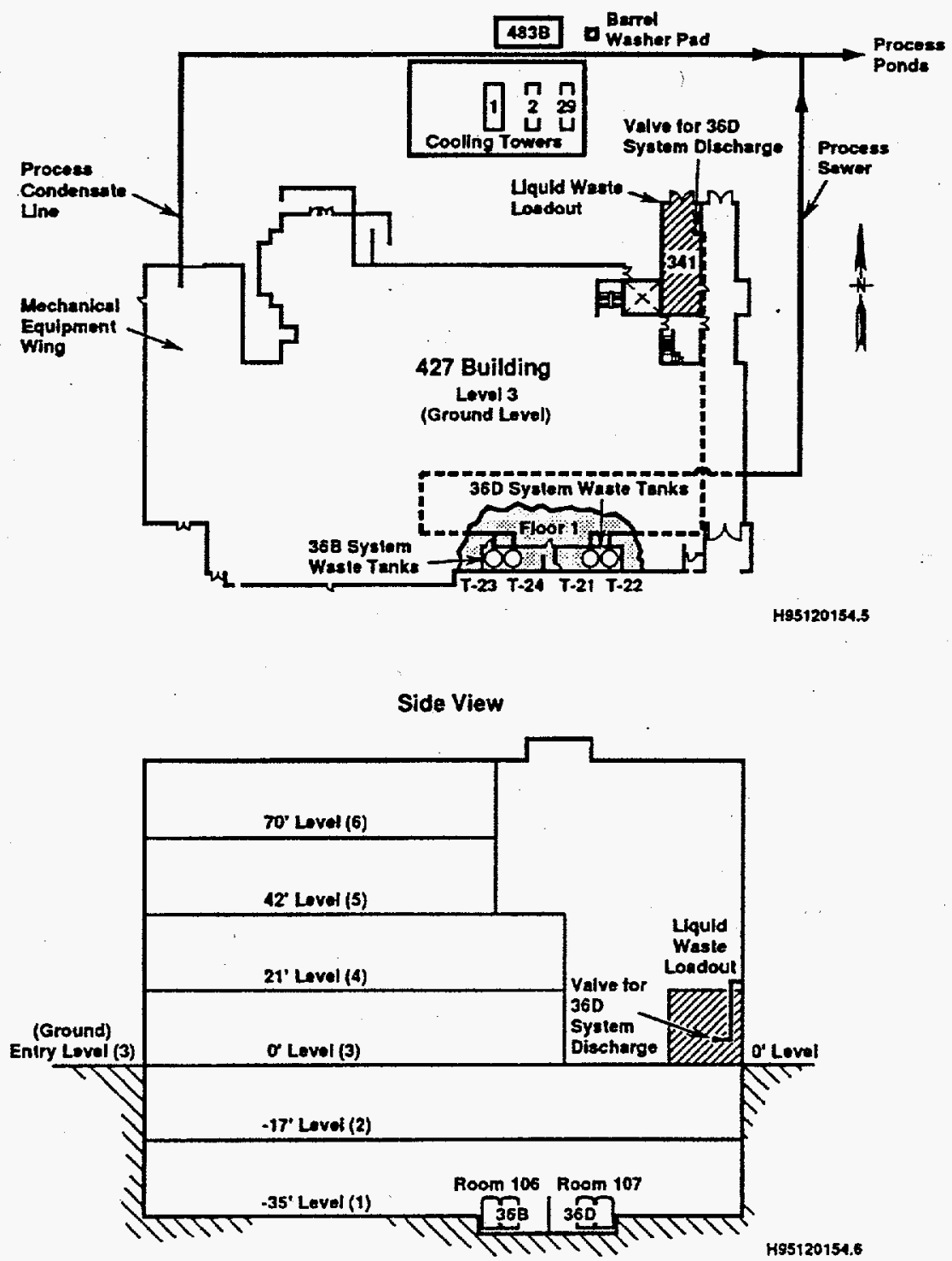

Figure 4. Fuels and Materials Examination Facility--Plan View. 
-

•

• 
DOE/RL-94-89, Rev. 2

$01 / 96$

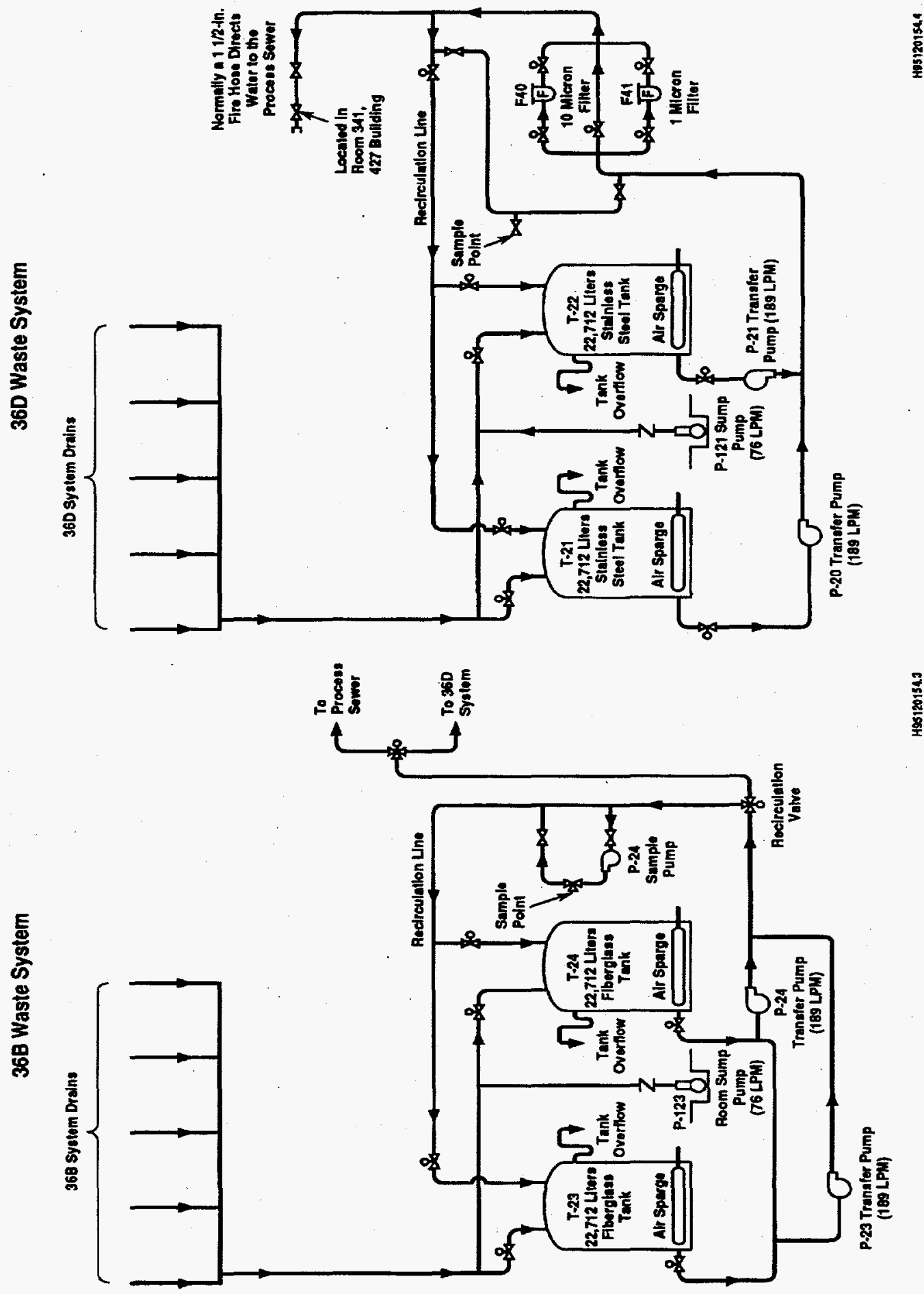

Figure 5. Fuels and Materials Examination Facility Process Waste Water Systems. 


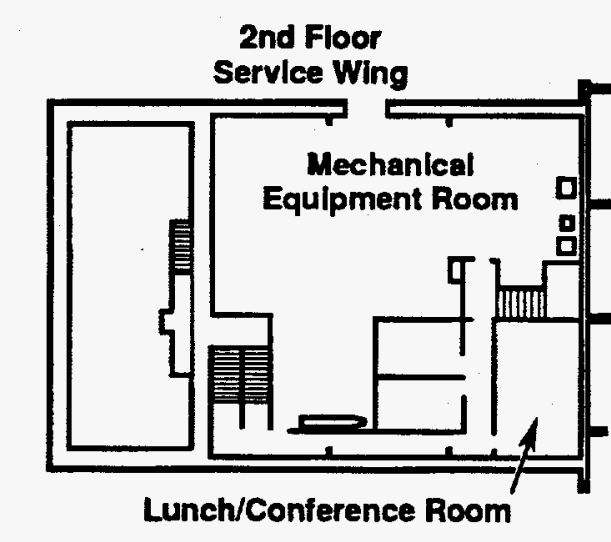

\section{T:}
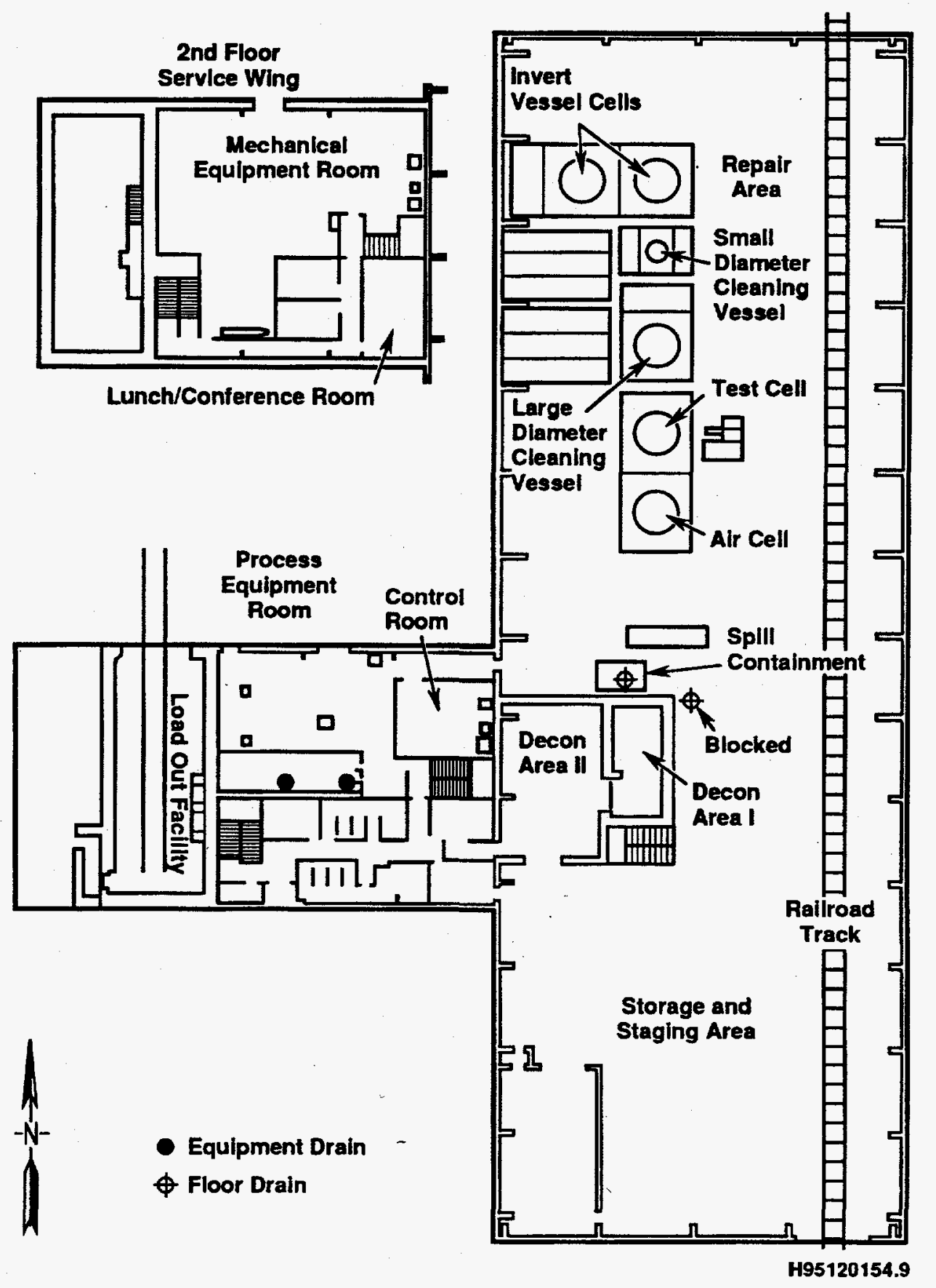

Figure 6. Maintenance and Storage Facility--Plan View. 


$$
\begin{array}{r}
\text { D0E/RL-94-89, Rev. } 2 \\
01 / 96
\end{array}
$$

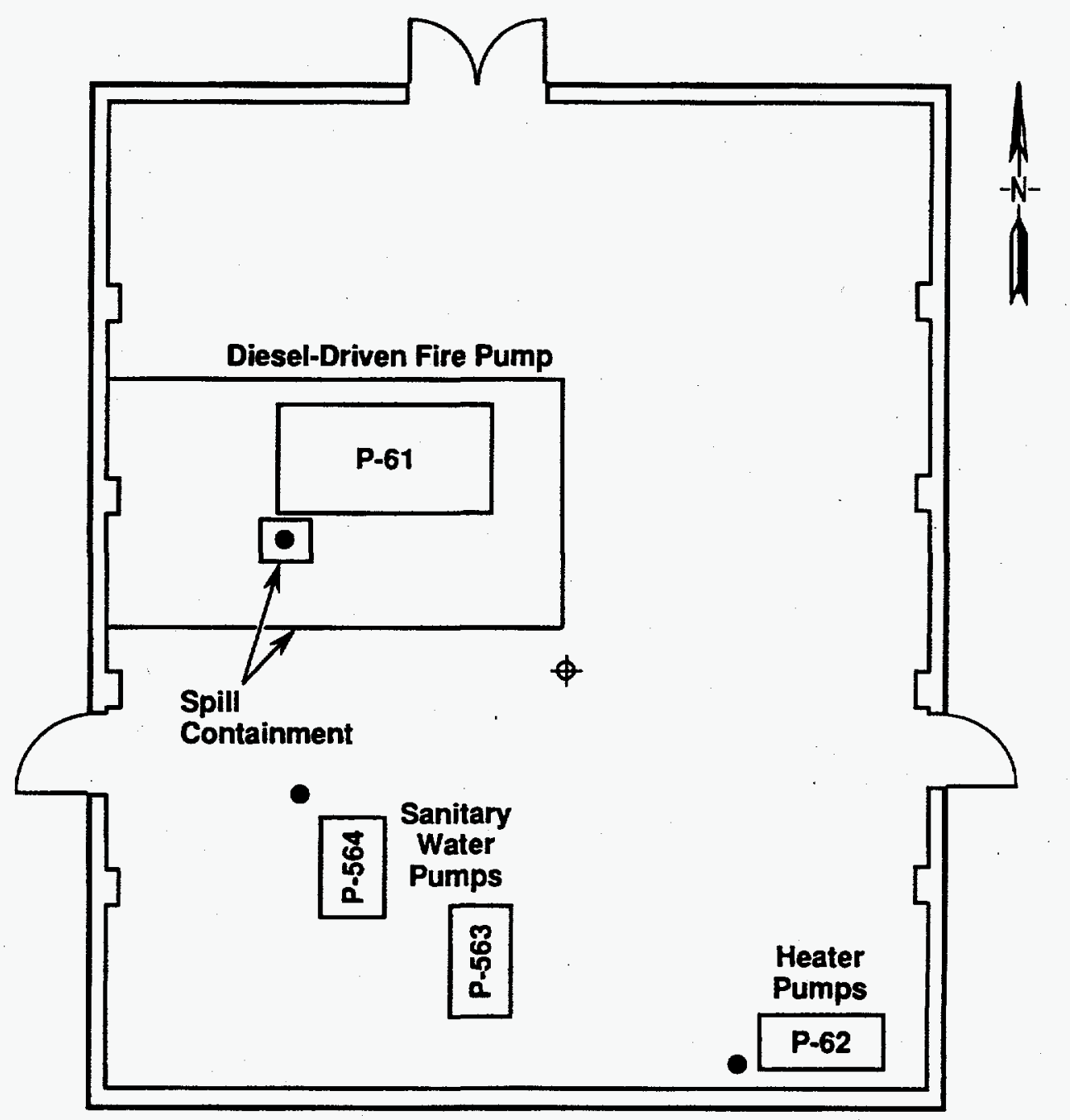

- Equipment Drain

\& Floor Drain

H95120154.7

Figure 7. 481-A Pumphouse. 
-

-

- 
Table 1. 400 Area Secondary Cooling Water System Source Status. (sheet 1 of 2)

\begin{tabular}{|c|c|c|}
\hline $\begin{array}{l}\text { Source } \\
\text { number }\end{array}$ & Source stream & Status \\
\hline 15 & Floor Drain - FMEF-404 & 36B system drain plugged by $4 M-92-00240 / M$. \\
\hline 16 & Floor Drain - FMEF-238 & $36 \mathrm{~B}$ system drain plugged by $4 \mathrm{M}-92-00240 / \mathrm{M}$. \\
\hline 17 & Floor Drain - FMEF & Routed to $36 \mathrm{~B}$ System. \\
\hline 18 & Floor Drain - FMEF-307 & $36 \mathrm{~B}$ system drain plugged by $4 \mathrm{M}-92-00240 / \mathrm{M}$. \\
\hline 19 & Floor Drain - FMEF & Routed to $36 \mathrm{~B}$ System. \\
\hline 20 & Floor Drain - FMEF & Routed to $36 \mathrm{~B}$ System. \\
\hline 21 & Floor Drain - FMEF-224 & $36 \mathrm{~B}$ system drain plugged by $4 \mathrm{M}-92-00240 / \mathrm{M}$. \\
\hline 22 & Floor Drain - FMEF & Routed to $36 \mathrm{~B}$ System. \\
\hline 23 & Floor Drain - FMEF & 36B system drain plugged by $4 \mathrm{M}-92-00240 / \mathrm{M}$. \\
\hline 24 & Floor Drain - FMEF-204 & $36 \mathrm{~B}$ system drain plugged by $4 M-92-00240 / M$. \\
\hline 25 & Floor Drain - FMEF-206 & $36 \mathrm{~B}$ system drain plugged by $4 \mathrm{M}-92-00240 / \mathrm{M}$. \\
\hline 26 & Floor Drain - FMEF & Routed to $36 \mathrm{~B}$ System. \\
\hline 27 & Floor Drain - FMEF & Routed to 36B System. \\
\hline 28 & Floor Drain - FMEF-300 & 36B system drain plugged by $4 M-92-00240 / M$. \\
\hline $29-42$ & Floor Drain - FMEF-352 & 36B system drain plugged by $4 M-92-00240 / M$. \\
\hline $44-47$ & Floor Drain - FMEF & $\begin{array}{l}\text { Bermed to prevent spills from discharging } \\
\text { to process sewer. }\end{array}$ \\
\hline 48 & $\begin{array}{l}\text { Process Water Pressure } \\
\text { Re1ief Drain - FMEF } \\
\end{array}$ & $\begin{array}{l}\text { Bermed to prevent spills from discharging } \\
\text { to process sewer. }\end{array}$ \\
\hline $49-51$ & Floor Drain - FMEF & $\begin{array}{l}\text { Bermed to prevent spills from discharging } \\
\text { to process sewer. }\end{array}$ \\
\hline 60 & Equipment Drain & $\begin{array}{l}\text { Bermed to prevent spills from discharging } \\
\text { to process sewer. }\end{array}$ \\
\hline 62 & Floor Drain - MASF-HB & Drain has been permanently plugged. \\
\hline 63 & Floor Drain - MASF-HB & $\begin{array}{l}\text { Bermed to prevent spills from discharging } \\
\text { to process sewer. }\end{array}$ \\
\hline 64 & $\begin{array}{l}\text { Air Compressor Cooling } \\
\text { Water - MASF-ER }\end{array}$ & Bermed under 4A-92-00065/W. \\
\hline
\end{tabular}


Table 1. 400 Area Secondary Cooling Water System Source Status. (sheet 2 of 2)

\begin{tabular}{|c|l|l|}
\hline $\begin{array}{c}\text { Source } \\
\text { number }\end{array}$ & \multicolumn{1}{|c|}{ Source stream } & \multicolumn{1}{|c|}{ Status } \\
\hline \hline 65 & $\begin{array}{l}\text { Equipment Drain - } \\
\text { MASF-ER }\end{array}$ & Bermed under 4A-92-00065/W. \\
\hline 66 & Floor Drain in 481-A & $\begin{array}{l}\text { A rubber plug has been installed on the } \\
\text { drain cover under 4F-92-00940/W. An } \\
\text { engraved plate has been installed on the } \\
\text { plug stating that the plug can only be } \\
\text { removed by obtaining the concurrence of } \\
\text { FFTF regulatory compliance. }\end{array}$ \\
\hline 67 & $\begin{array}{l}\text { Sanitary Water Pump } \\
\text { Leakage - 481-A }\end{array}$ & $\begin{array}{l}\text { Drains service pump seal; 4-inch collars } \\
\text { have been installed. }\end{array}$ \\
\hline 68 & Equipment Drain - 481-A & $\begin{array}{l}\text { Drains service pump seal; 4-inch collars } \\
\text { have been installed. }\end{array}$ \\
\hline 69 & Equipment Drain - 481-A & $\begin{array}{l}\text { Drains service pump seal; 4-inch collars } \\
\text { have been installed. }\end{array}$ \\
\hline 70 & Janitor Sink - 481-A & $\begin{array}{l}\text { Drains service pump seal; 4-inch collars } \\
\text { have been installed. }\end{array}$ \\
\hline
\end{tabular}


DOE/RL-94-89, Rev. 2

$01 / 96$

\section{ATTACHMENT D}

\section{MATERIALS STORED ONSITE}

(SECTION C - ITEM 7) 
DOE/RL-94-89, Rev. 2

$01 / 96$

This page intentionally left blank. 


\section{ATTACHMENT D}

MATERIALS STORED ONSITE

(SECTION C - ITEM 7)

\begin{tabular}{|c|c|c|}
\hline Materials & Quantity & Medium \\
\hline Acetone & 25 liters & $L$ \\
\hline Acetylene (compressed gas) & 37,400 1iters & G \\
\hline Air (compressed gas) & 375,000 1iters & G \\
\hline Amercoat Thinner & 80 1iters & $L$ \\
\hline Argon (compressed gas) & 415,125 liters & G \\
\hline Argon (1 iquid) & 36,0001 iters & $\mathrm{L}$ \\
\hline Carboline thinner 15 & 201 iters & $L$ \\
\hline Castor oil & 450 1iters & $L$ \\
\hline Dearborn 726 & 8401 iters & $L$ \\
\hline Dearborn CW 1509 & 174 Titers & $L$ \\
\hline Dearborn 878 & 2,100 1iters & $\mathrm{L}$ \\
\hline Dearcide 702 & 3,750 liters & $\mathrm{L}$ \\
\hline Diesel fuel & 249,500 liters & $L$ \\
\hline Dowtherm SR-1 heat transfer fluid & 178,0001 iters & $\mathrm{L}$ \\
\hline Freon 22 & $3,650 \mathrm{ki}$ lograms & $L$ \\
\hline Freon 12 & 185 kilograms & $L$ \\
\hline Gas mixtures $\left(\mathrm{CO}_{2}, \mathrm{O}_{2}, \mathrm{~N}_{2}, \mathrm{He}, \mathrm{H}_{2}, \mathrm{Ar}\right)$ & 140,000 liters & G \\
\hline Gasoline (unleaded) & 200 1iters & $L$ \\
\hline Grease (various types) & 1,000 kilograms & $S$ \\
\hline Helium (compressed gas) & 63,400 liters & G \\
\hline Hydrogen (compressed gas) & 6,2301 iters & G \\
\hline Isopropyl alcohol & 401 iters & $L$ \\
\hline Kerosene & 3,000 1iters & $\mathrm{L}$ \\
\hline Lead & 7,625 liters & $\mathrm{S}$ \\
\hline
\end{tabular}




\begin{tabular}{|c|c|c|}
\hline Materials & Quantity & Medium \\
\hline Lubricating oil/hydraulic oil & 17,500 liters & $\mathrm{L}$ \\
\hline Methyl ethyl ketone & 310 1iters & $\mathrm{L}$ \\
\hline Mineral spirits & 250 liters & $\mathrm{L}$ \\
\hline Mineral oil & 109,650 1iters & $L$ \\
\hline $\mathrm{Na}-X$ fire extinguisher & 900 ki lograms & $\mathrm{S}$ \\
\hline NaK (sodium potassium alloy) & 2,900 kilograms & $\mathrm{L}$ \\
\hline Naphtha petroleum (Skysol 100) & 625 liters & $L$ \\
\hline Nitrogen (compressed gas) & 533,100 1iters & G \\
\hline Nitrogen (1 iquid) & 68,140 liters & $L$ \\
\hline Oxygen (compressed gas) & 50,200 liters & G \\
\hline Performance ice buster & $1,200 \mathrm{ki}$ lograms & $\mathrm{S}$ \\
\hline Phenoline 305 finish (Parts A \& B) & 640 liters & $\mathrm{L}$ \\
\hline Polychlorinated biphenyls & 100,260 liters & $L$ \\
\hline Propane & $110 \mathrm{ki}$ lograms & G \\
\hline Silica gel & 2,000 liters & $\mathrm{S}$ \\
\hline Sodium & 880,000 kilograms & $\mathrm{L}$ \\
\hline Sodium hypochlorite & 1,600 liters & $\mathrm{L}$ \\
\hline Sodium bicarbonate & 530 kilograms & $S$ \\
\hline Stargon & 57,200 1 iters & $\mathrm{L}$ \\
\hline Sulfuric acid & 8,700 kilograms & $L$ \\
\hline Trichlorofluoromethane & 11,000 kilograms & $S$ \\
\hline Union 140 solvent & 6,800 liters & $\mathrm{L}$ \\
\hline Xylene & 60 liters & $\mathrm{L}$ \\
\hline $40 \%$ ethylene glycol solution & 106,000 iters & $\mathrm{L}$ \\
\hline
\end{tabular}

G - Gas.

L - Liquid.

S - Solid. 
DOE/RL-94-89, Rev. 2

$01 / 96$

\section{ATTACHMENT E}

\section{COOLING WATER FLOWCHARTS}

(SECTION D - ITEM 3) 


\section{DOE/RL-94-89, Rev. 2 $01 / 96$}

This page intentionally left blank. 


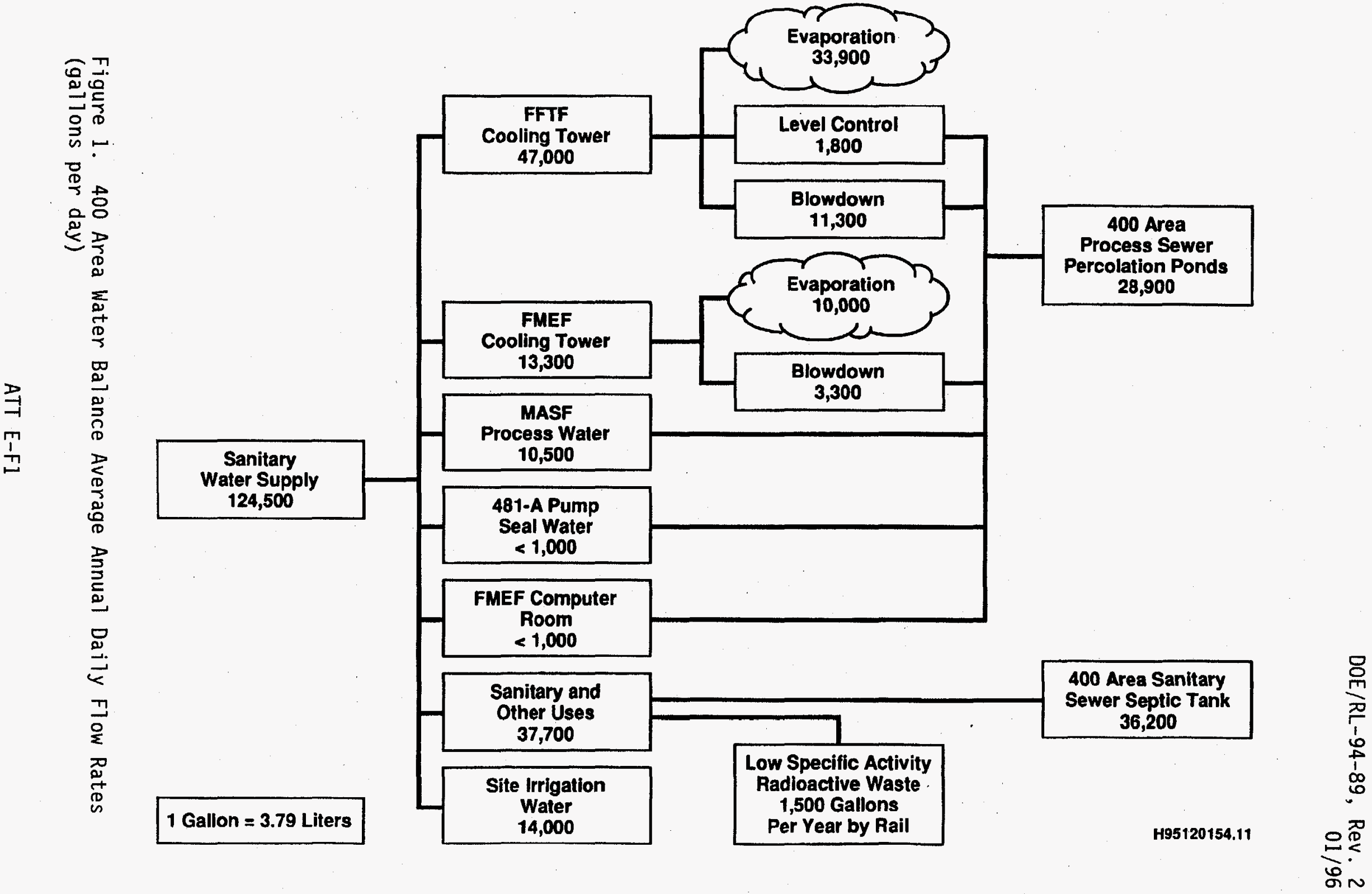




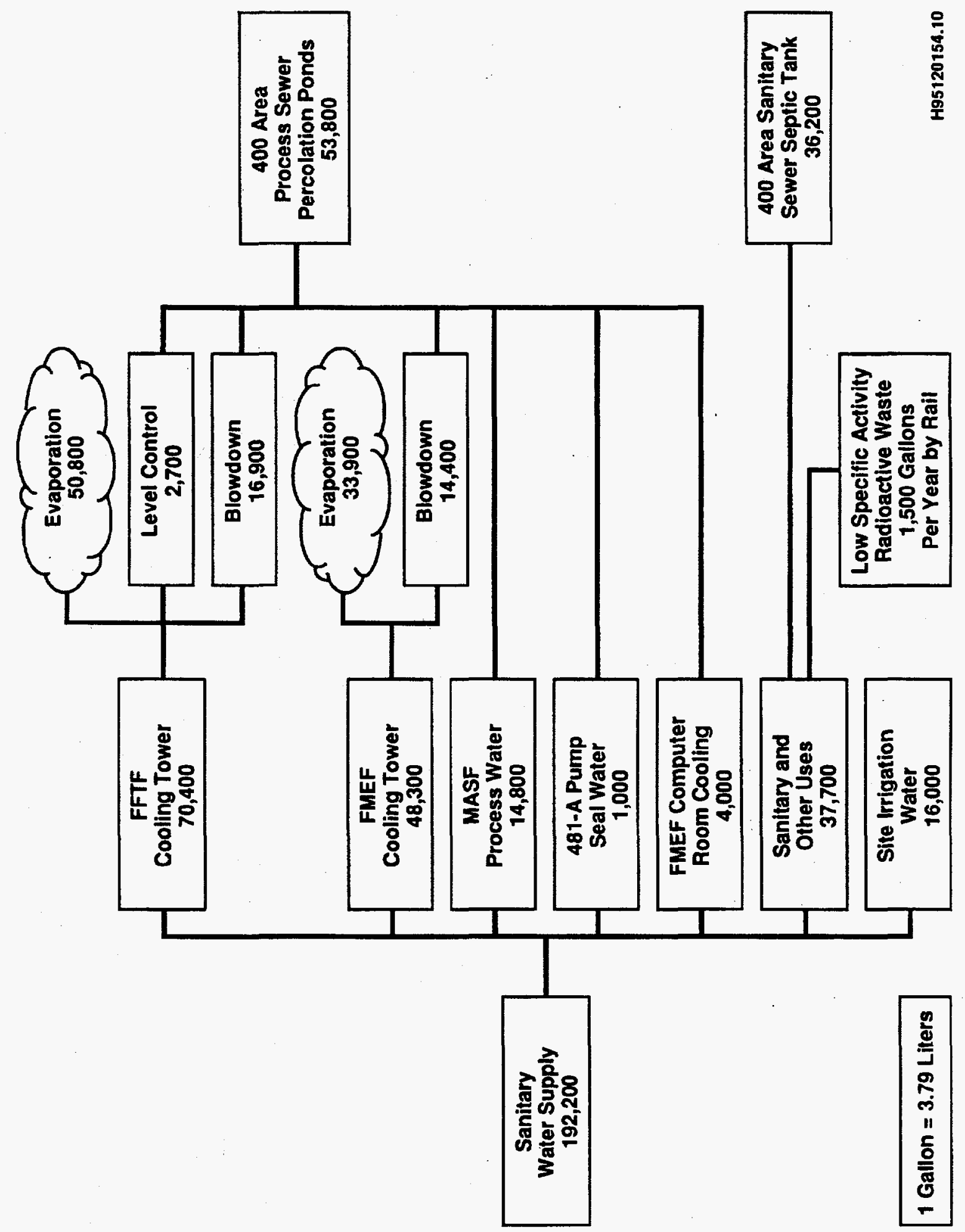

Figure 2. 400 Area Water Balance Peak Daily Flow Rates (gallons per day). 


\section{ATTACHMENT $\mathbf{F}$}

STORMWATER DISPOSAL MAP 
DOE/RL-94-89, Rev. 2

$01 / 96$

This page intentionally left blank. 
BUILOINO IYOEX

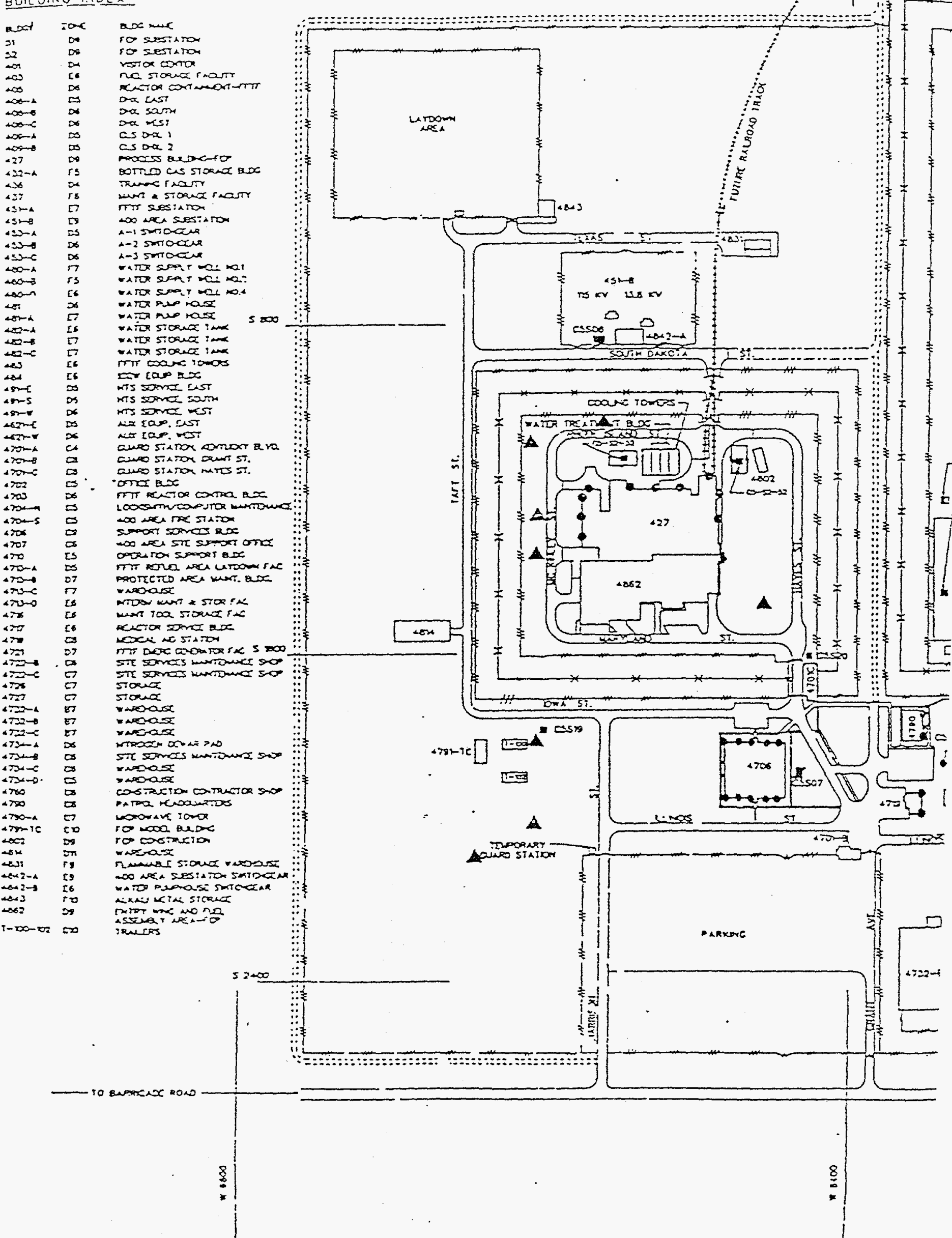


DOE/RL-94-89, Rev. 2

$01 / 96$

\section{ATTACHMENT $\mathbf{G}$}

\section{AREA TOPOGRAPHIC MAPS}




\section{DOE/RL-94-89, Rev. 2}

This page intentionally left blank. 
DISTRIBUTION

OFFSITE

MSIN

Washington State Department of Ecology Kennewick, WA

Greta B. Davis

Melodie A. Selby (2)

B5-18

U.S. Environmental Protection Agency Region 10

Richland. WA

Doug Sherwood

B5-01

J. Wilkinson

Confederated Tribes of the Umatilla

Indian Nation

P. 0. Box 638

Pendleton, Oregon 97801

D. Powaukee

Nez Perce Tribe

B5-18

P. 0. Box 365

Lapwai, Idaho 93540

R. Jim, Manager

Environmental Restoration/

Waste Management Program

Yakama Indian Nation

P. 0. Box 151

Toppenish, Washington 98948

ONSITE

U.S. Department of Energy. Richland Operations office

D. H. Chapin

A5-15

O. A. Farabee

N2-36

R. N. Krekel

N2-36

J. E. Mecca

R3 -79

OSTI (2)

Reading Room (2)

E6-44

$\mathrm{H} 2-53$ 


\section{UNITED STATES}

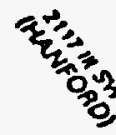
DEPARTMENT OF THE INTERIOR GEOLOOICAL SURYEY

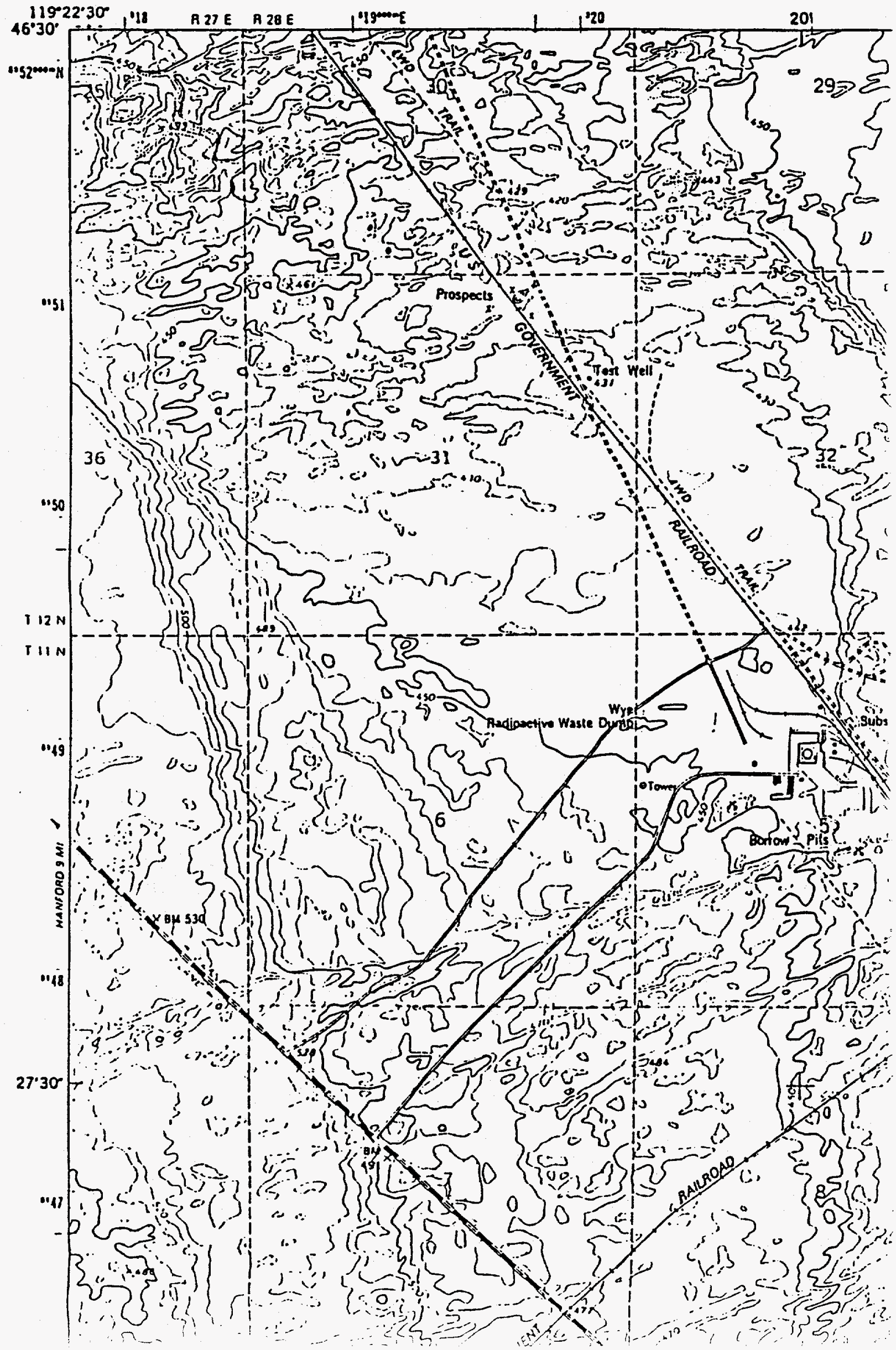




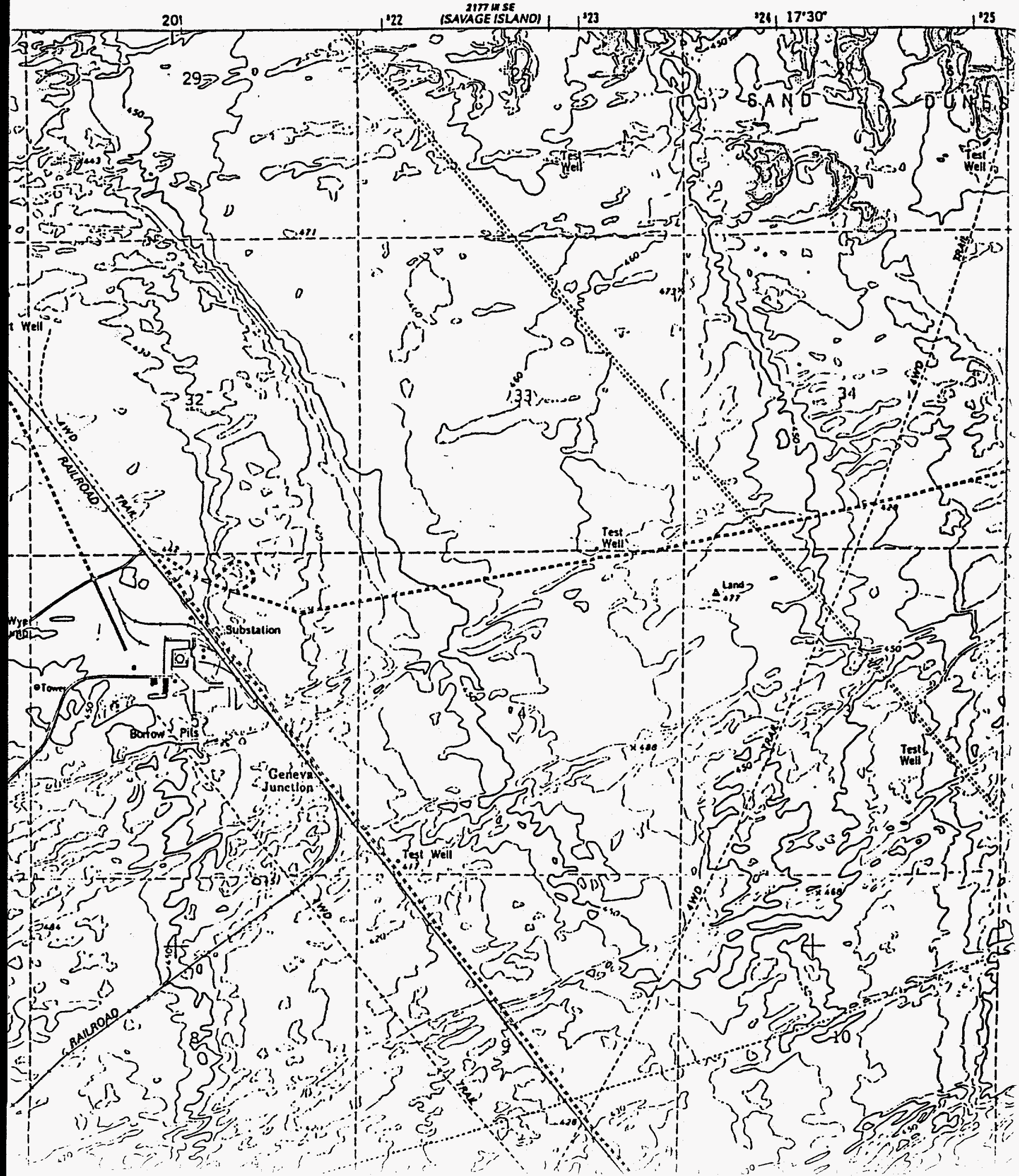




\section{WOODED ISLAND QUADRANGLE WASHINGTON \\ 7.5 MINUTE SERIES (TOPOGRAPHIC)}

125
Hex

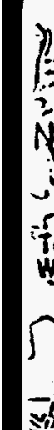

\section{5}

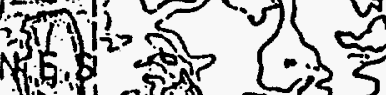

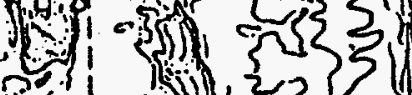

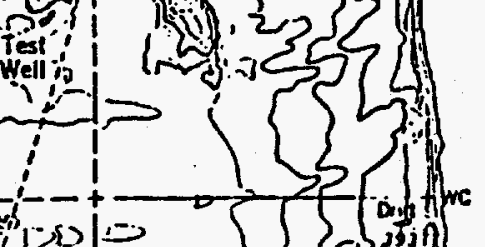

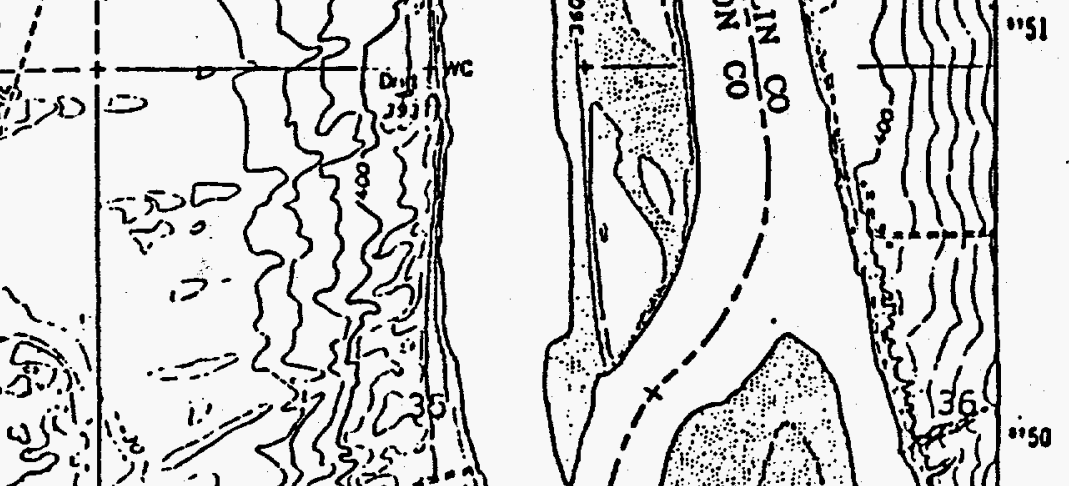
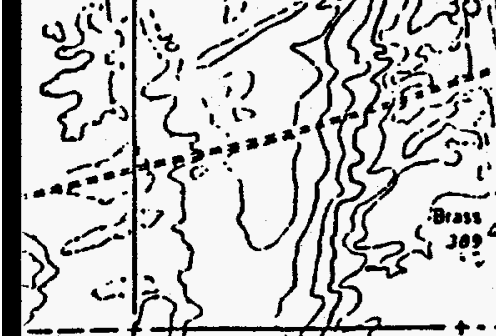

?
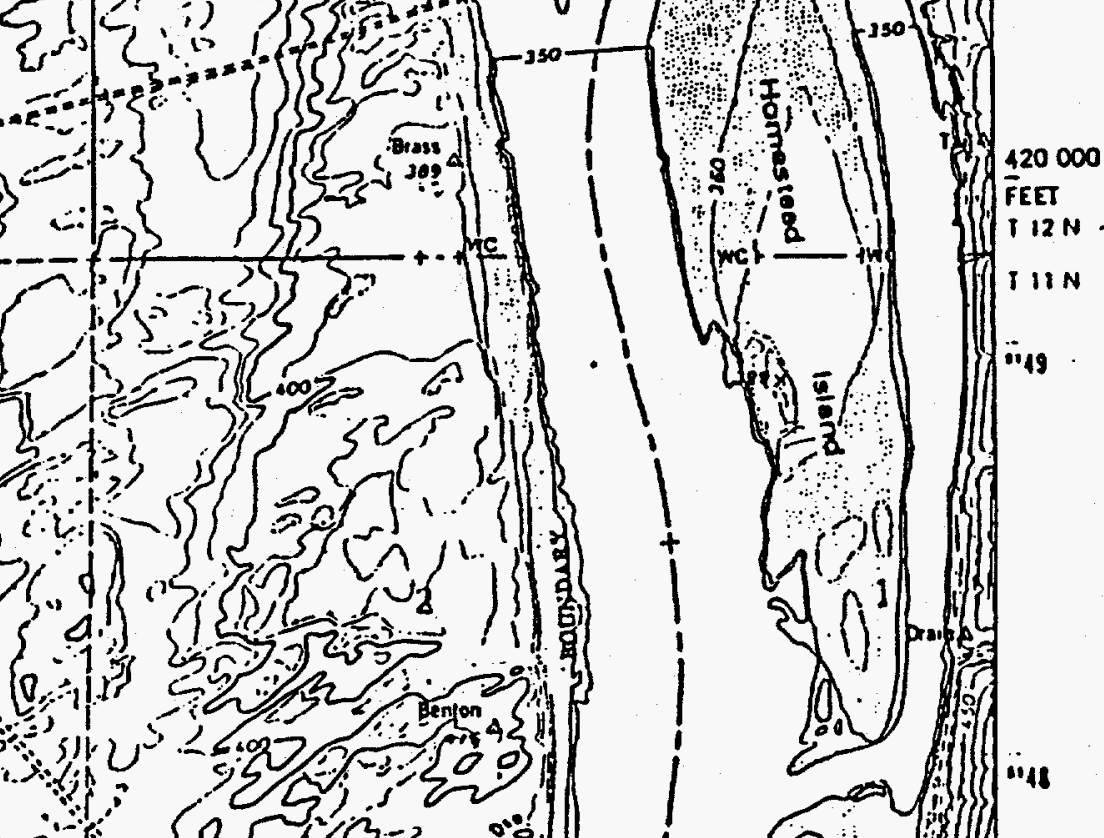

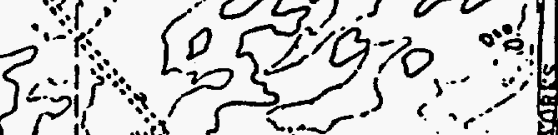

s.
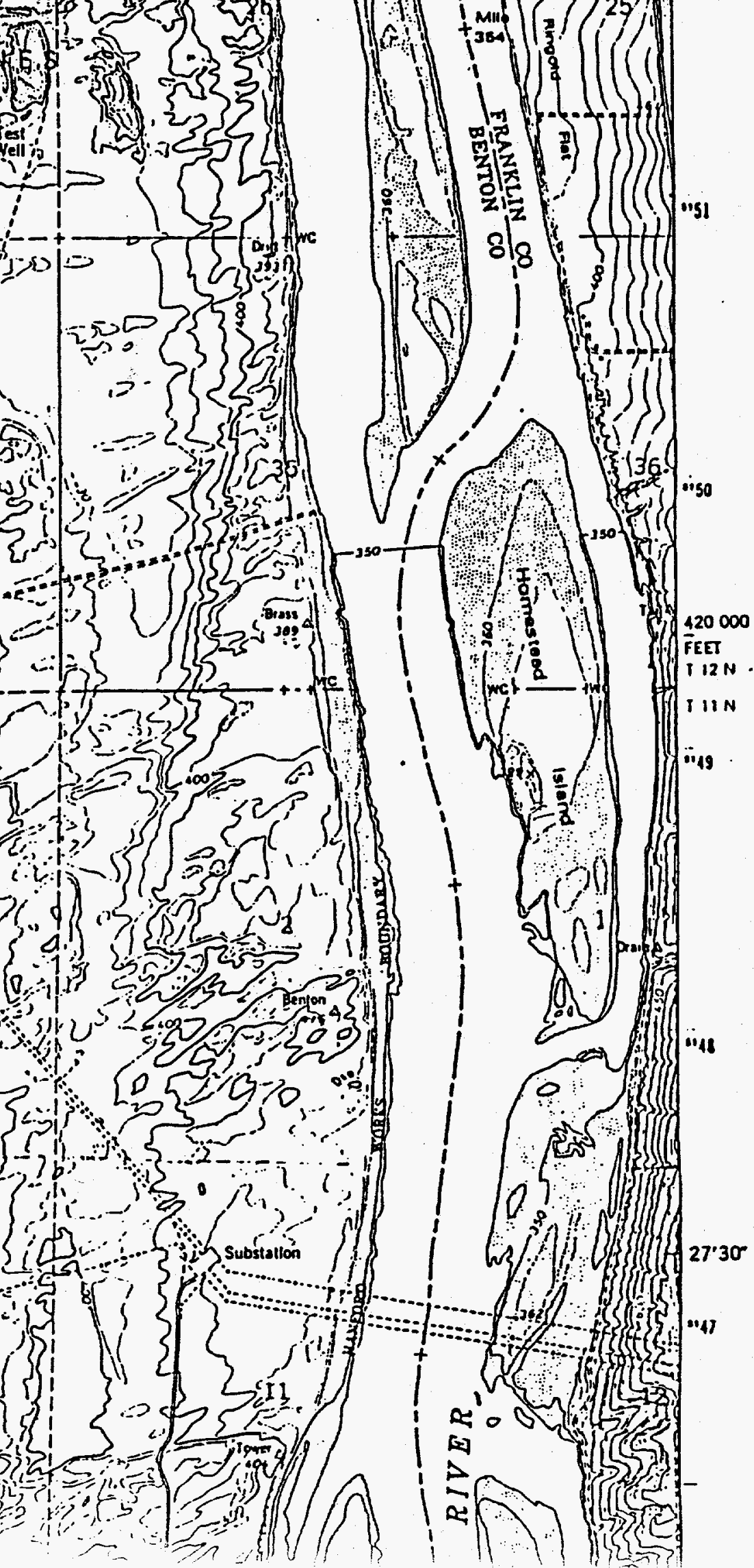

FET

$112 \mathrm{~N}$.

I $11 \mathrm{~N}$

"19

118 







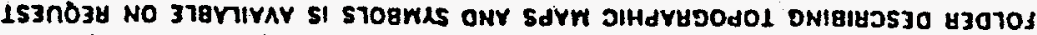

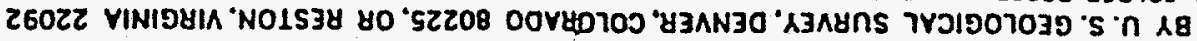
SOYYONY1S lOVYNOOY dYW TYNOIIYN HLIM S3I7dWOO dYW SIHI

aOOM

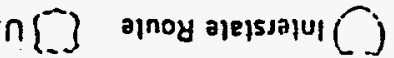

วכe|ins pjey

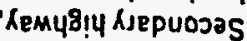

aวejuns piey Кем48!प Lew!rd
NoIrboา 3าפผrצorno

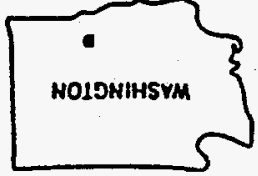

$\xi$

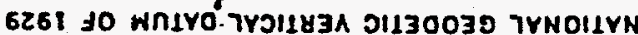

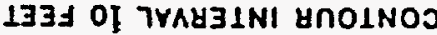

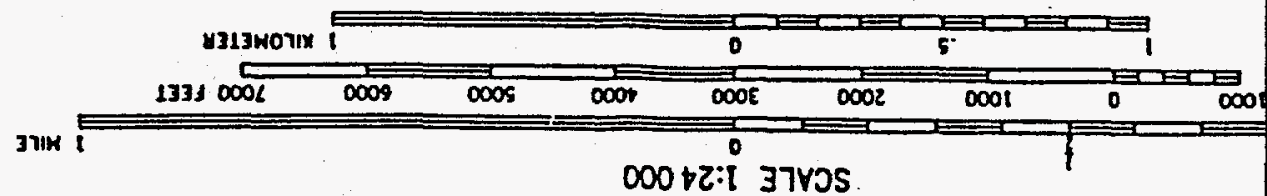

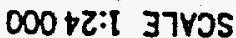

istio aroy

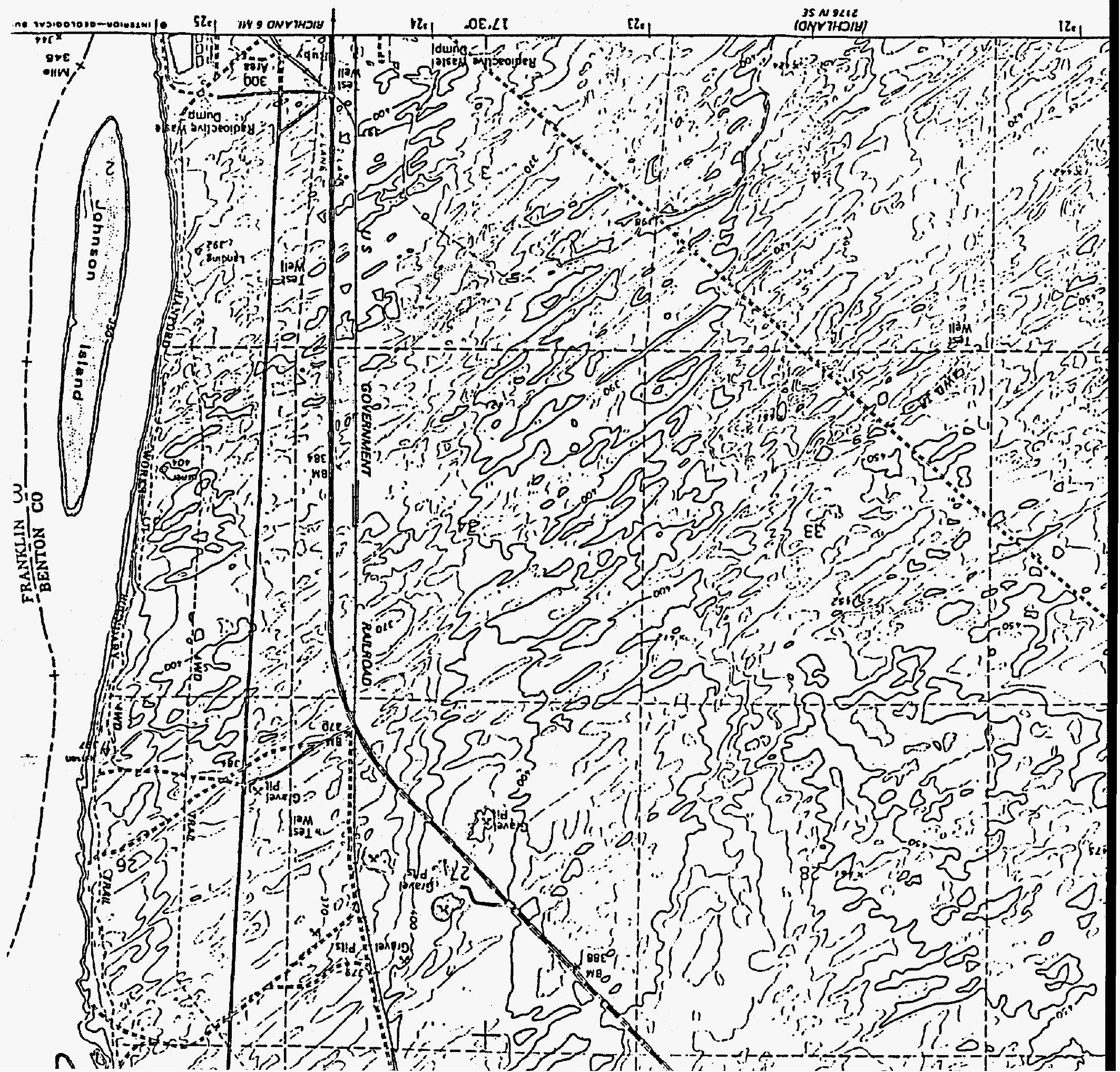




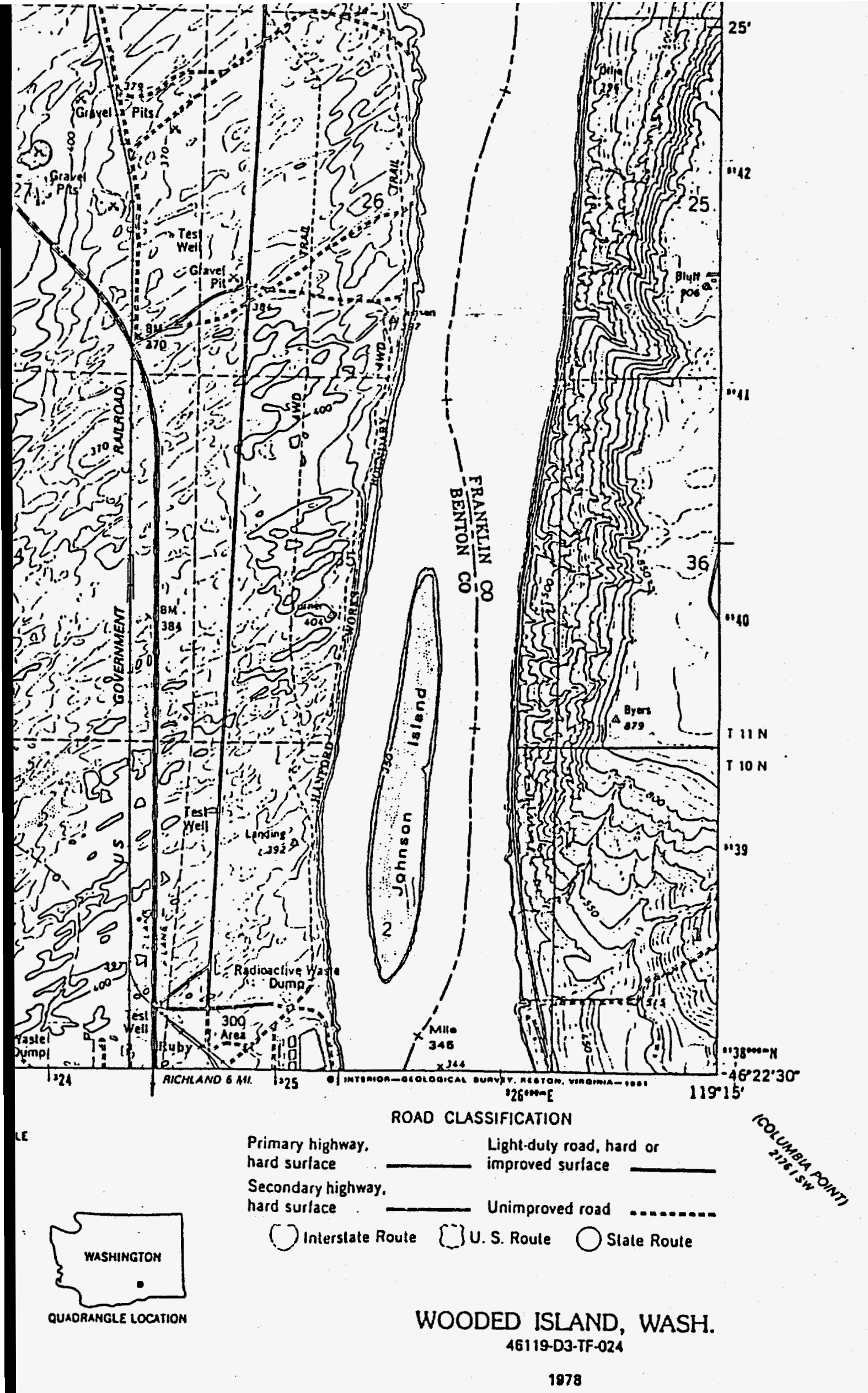

DMA 2176 N NE-SERIES VB9! 


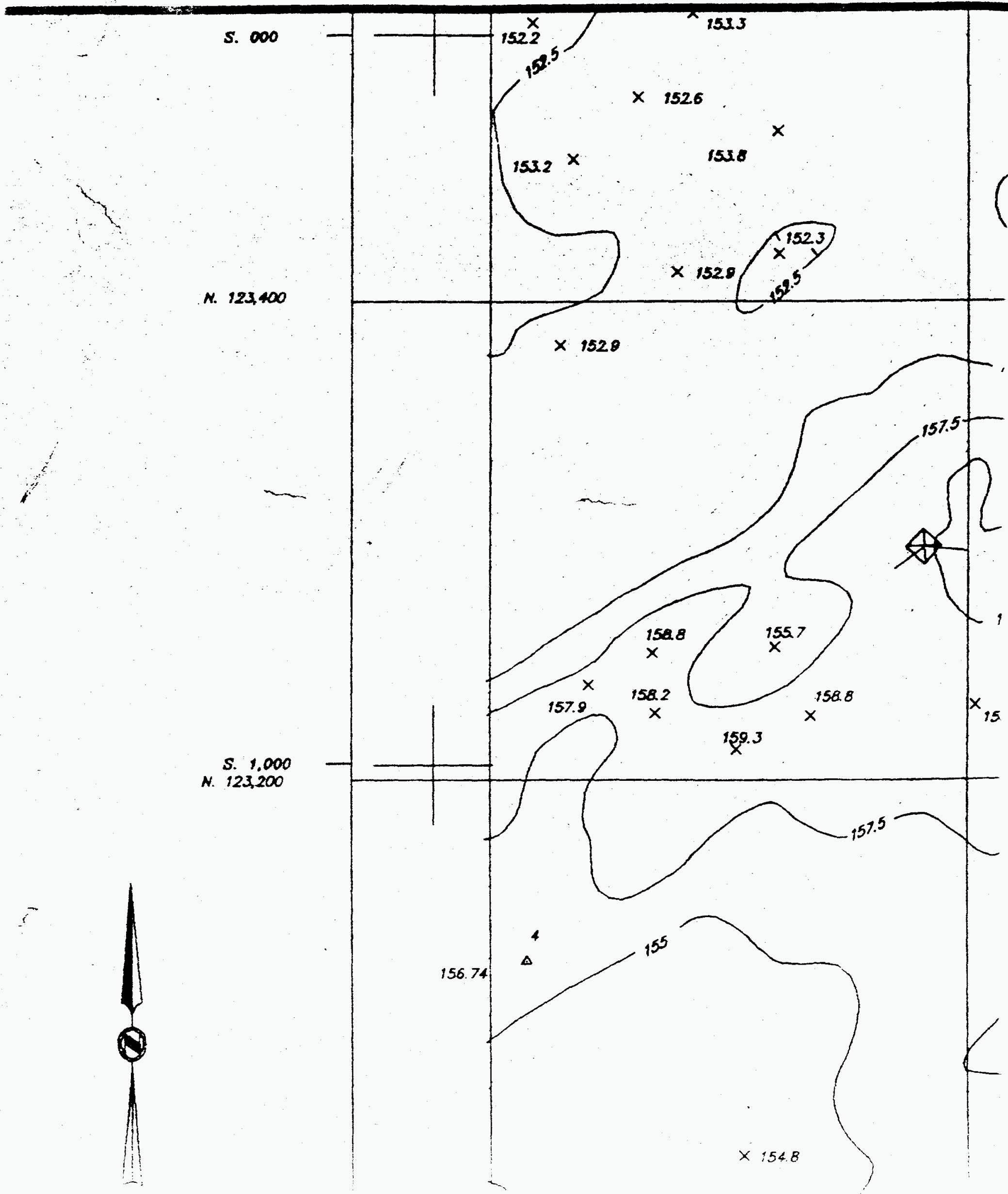


7

6

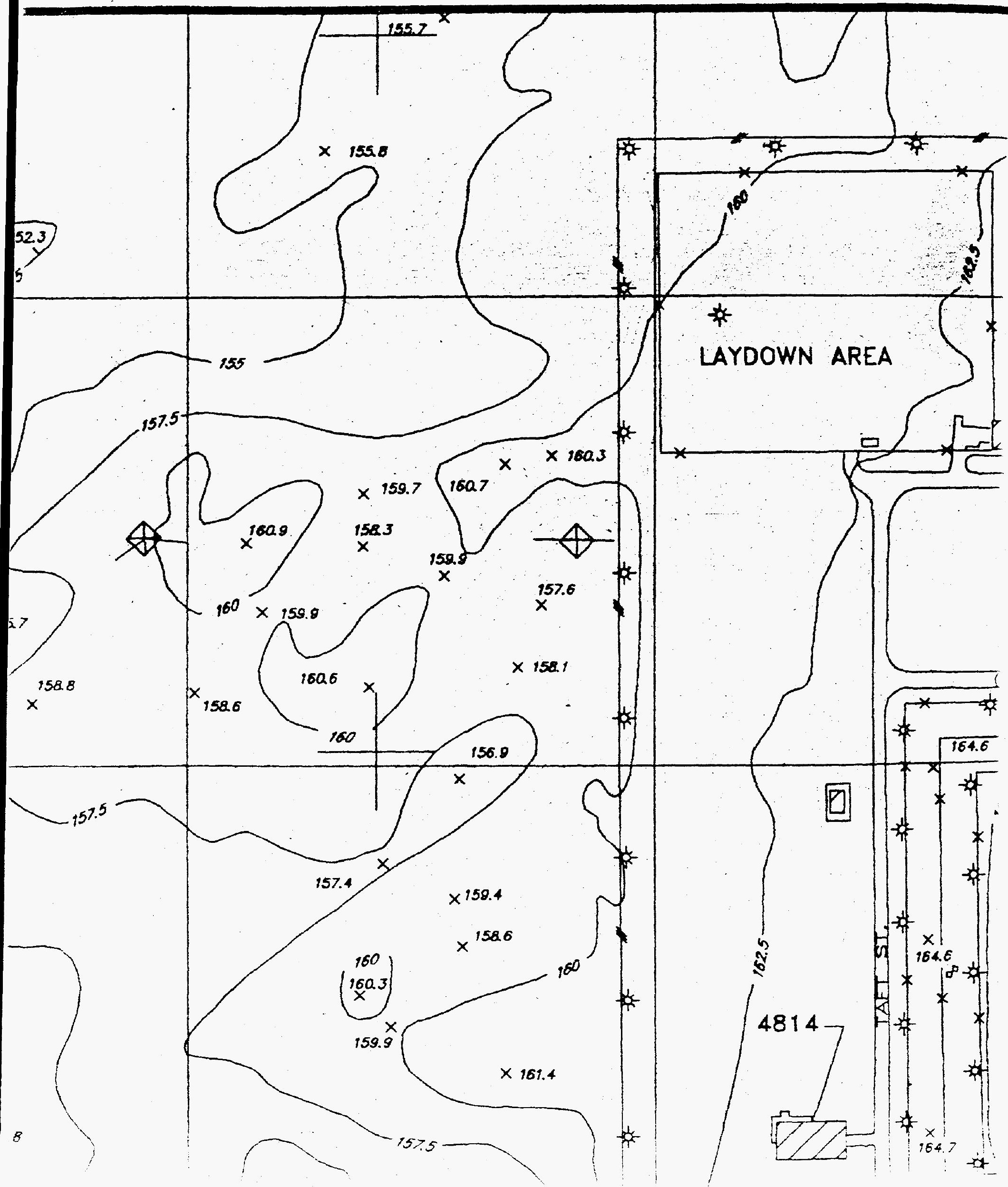




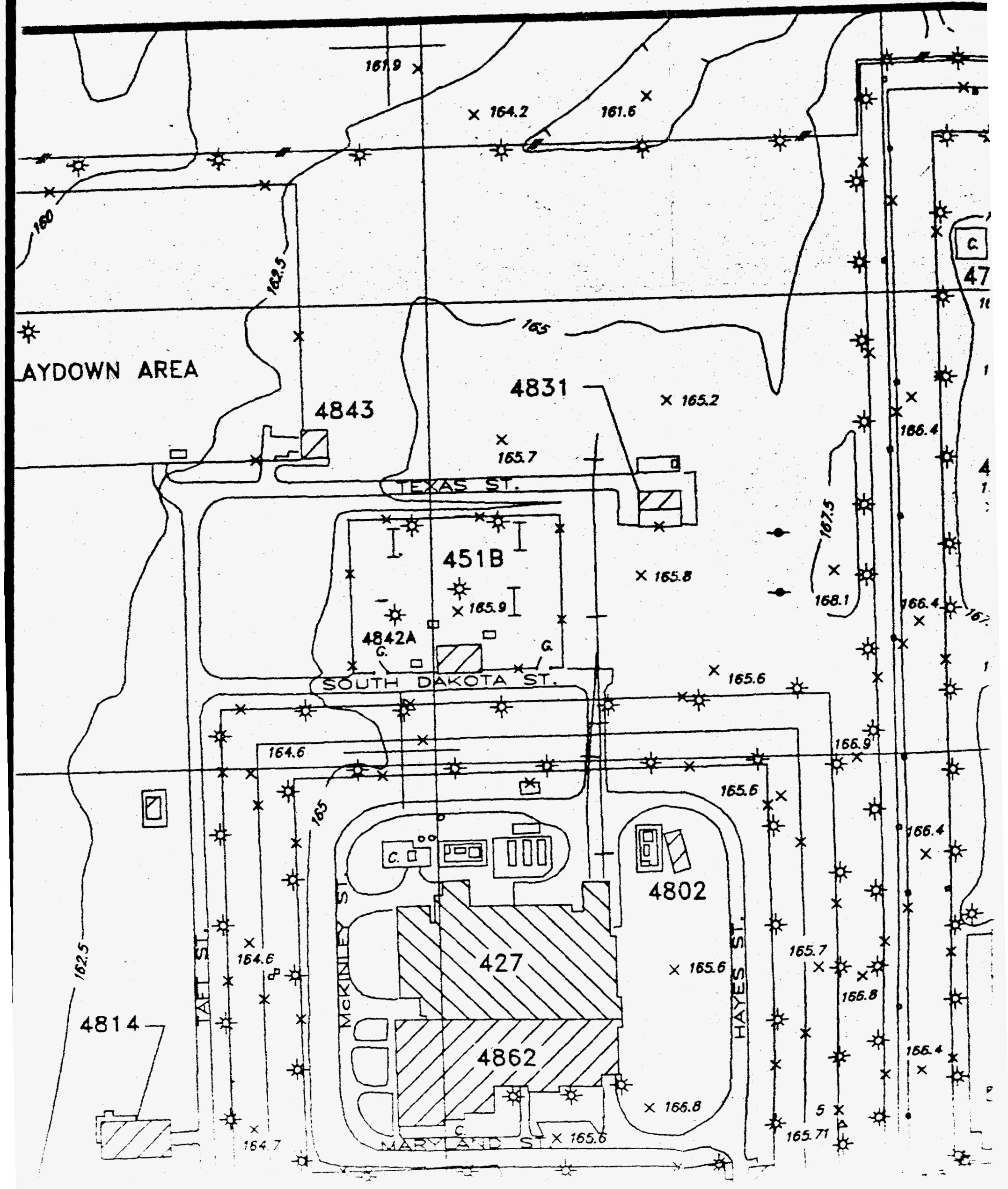




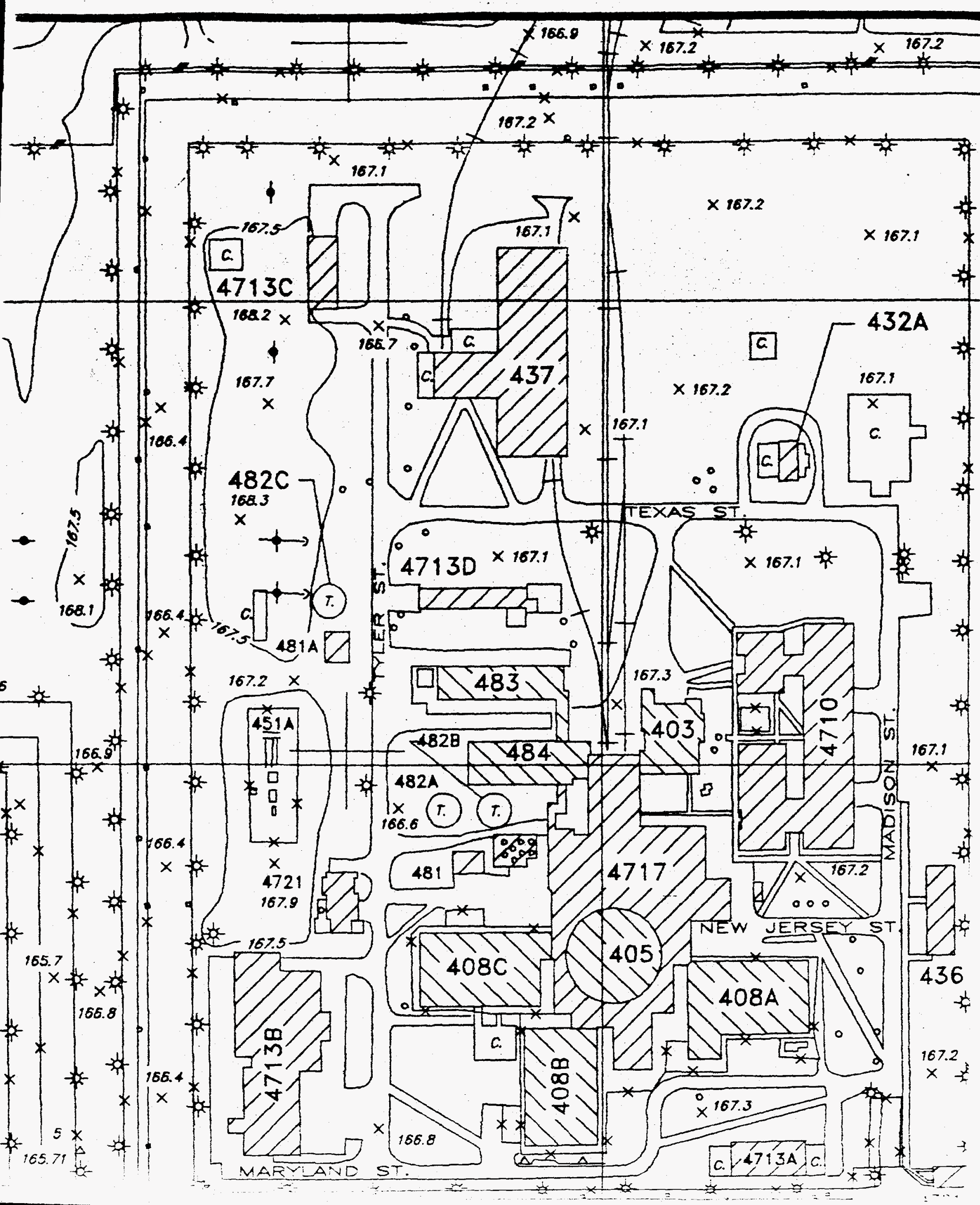




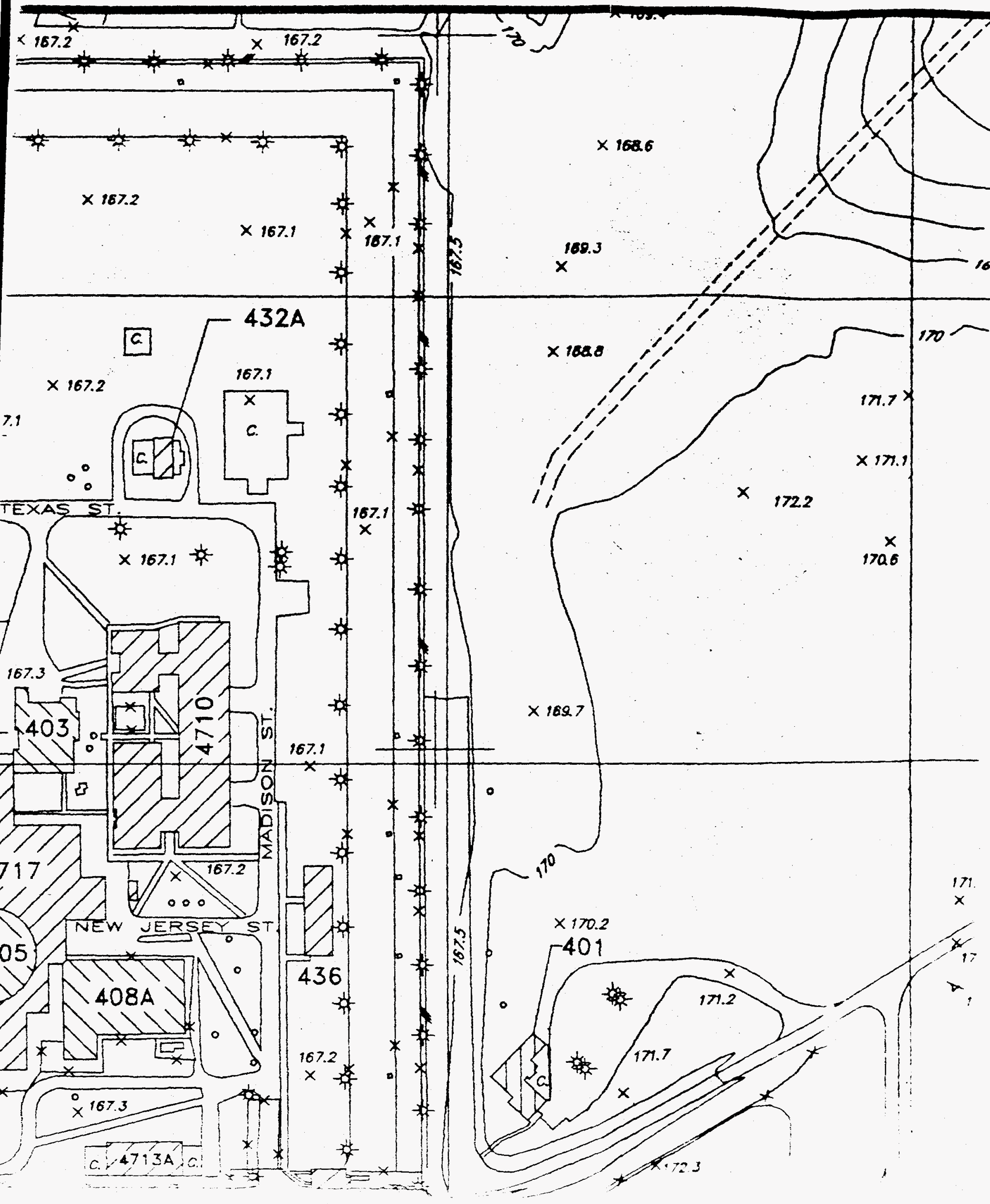




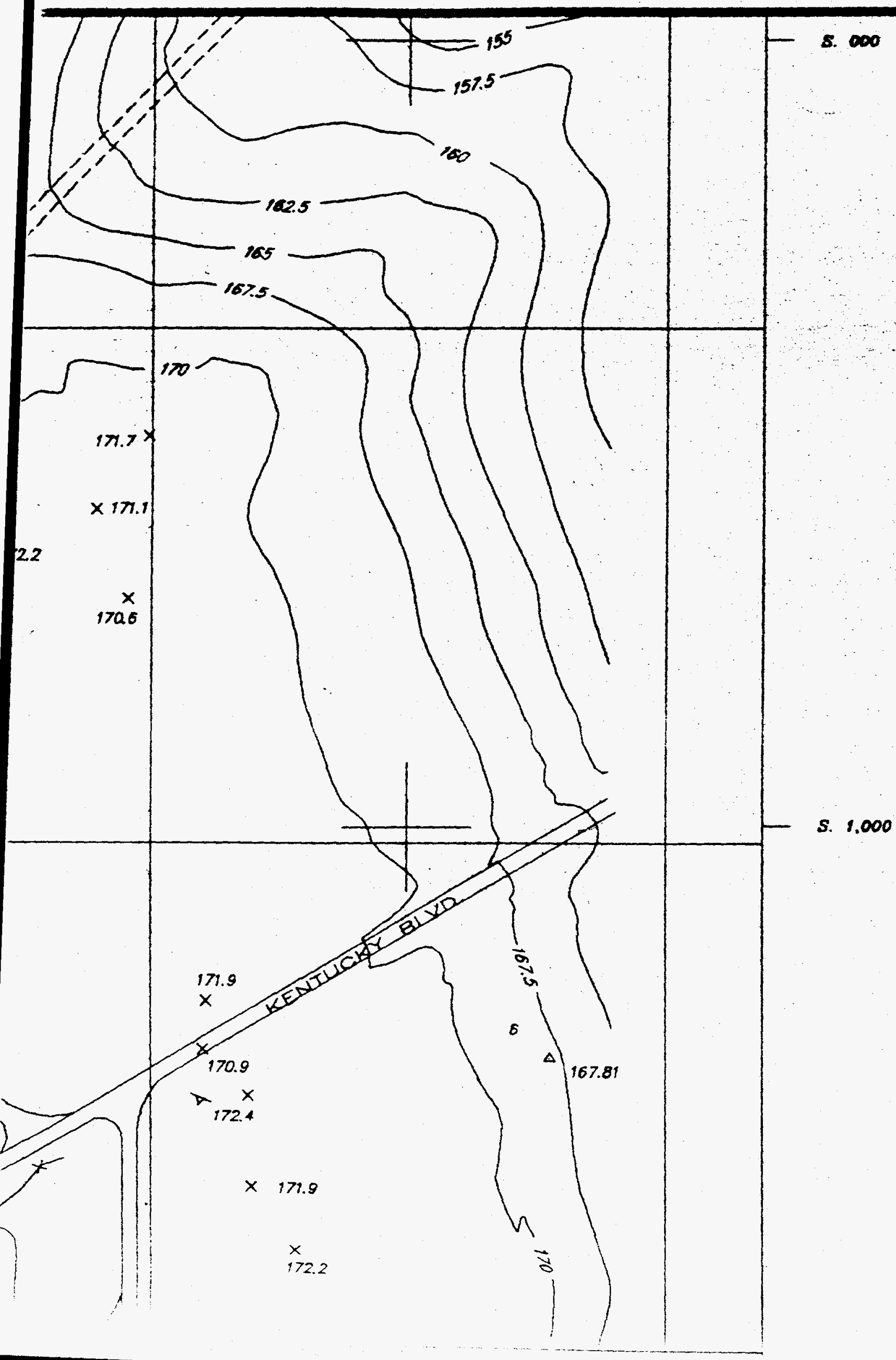




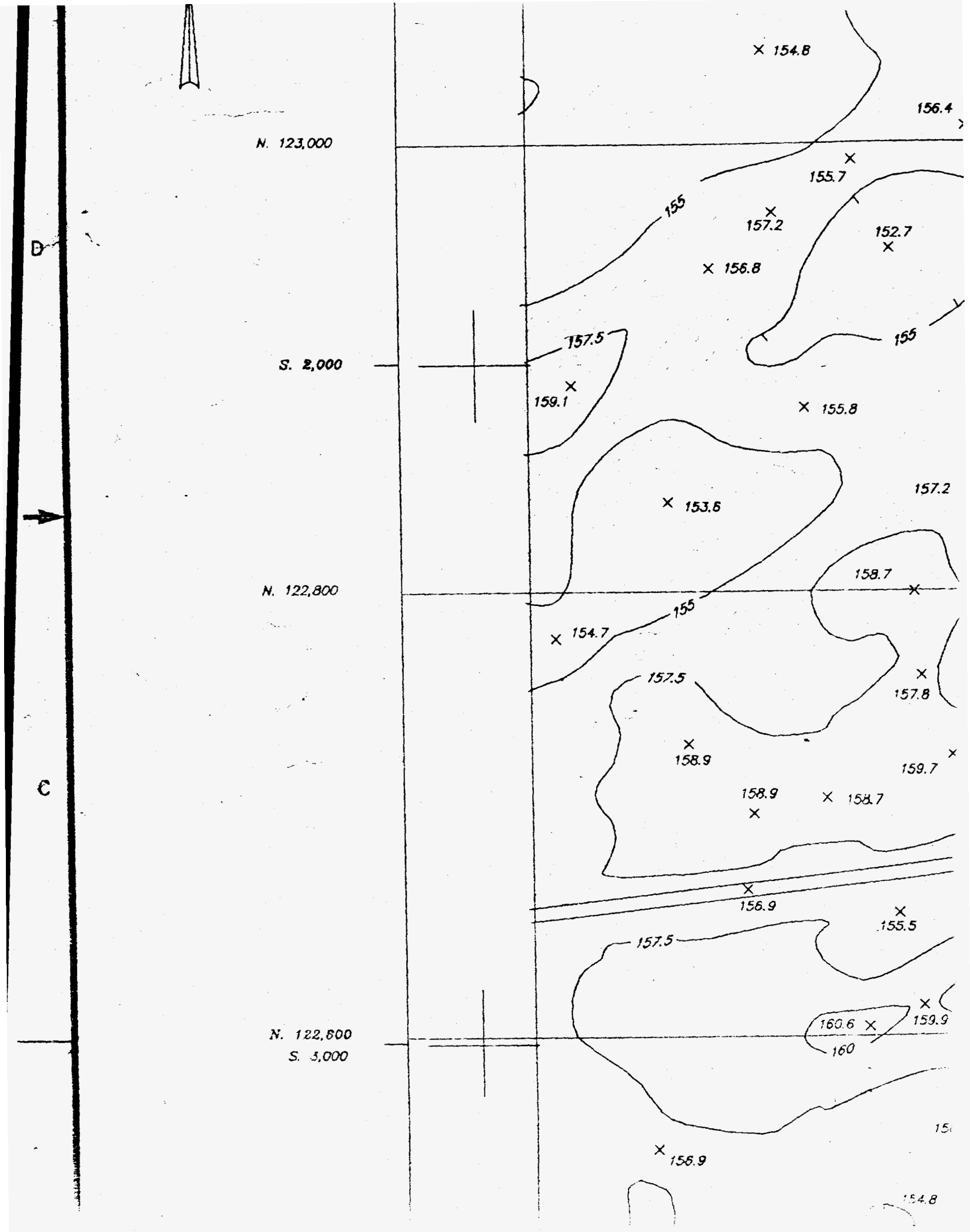




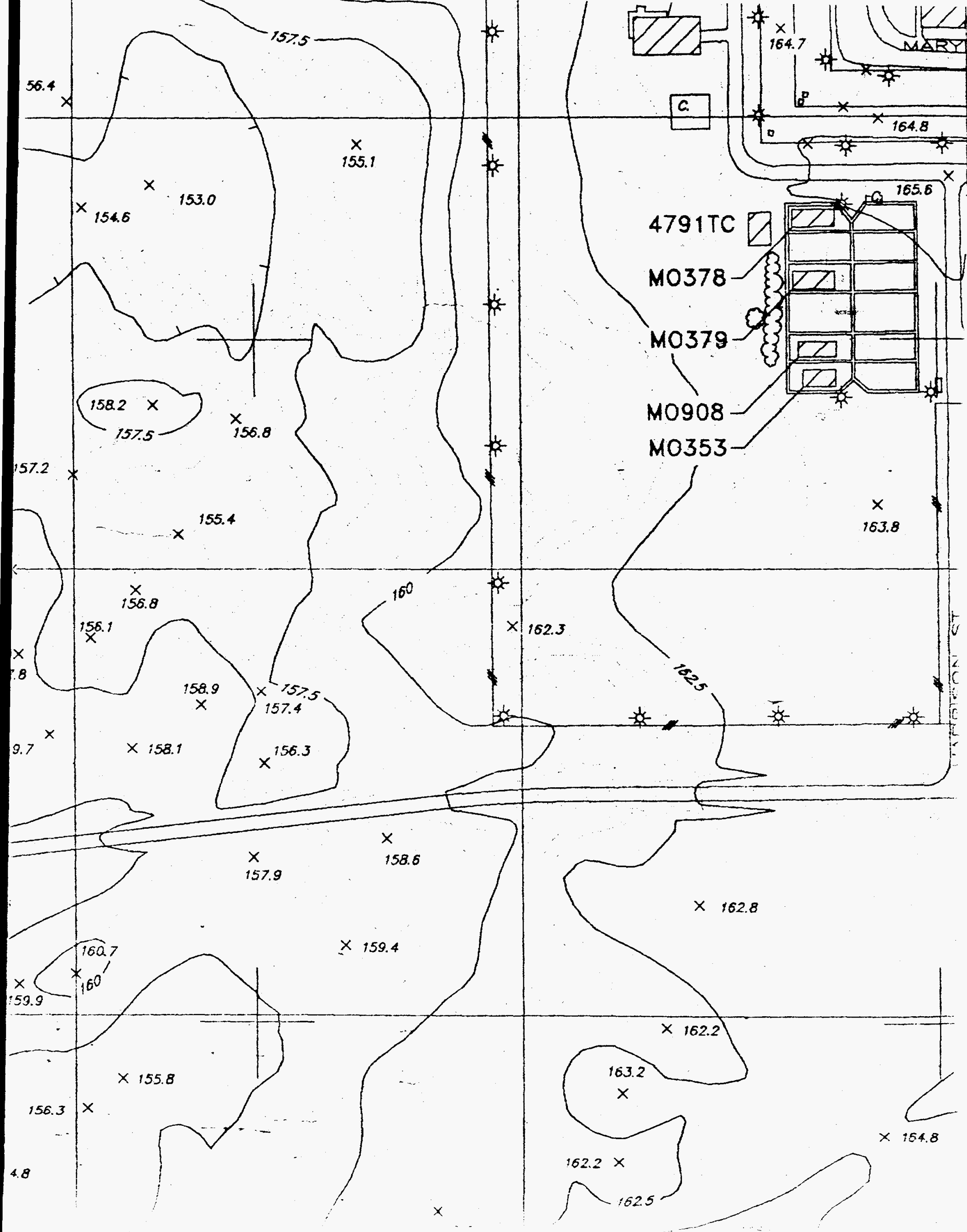




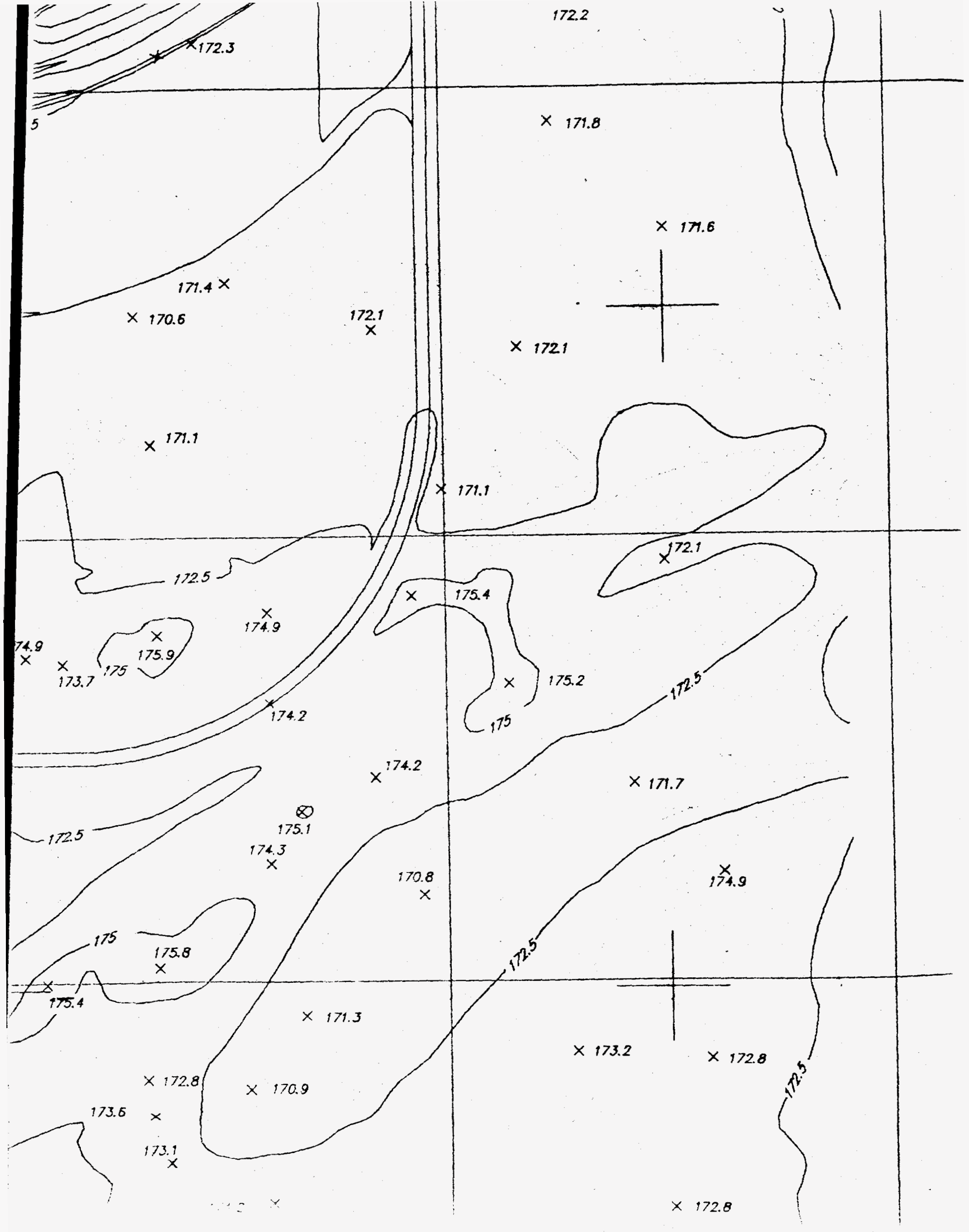




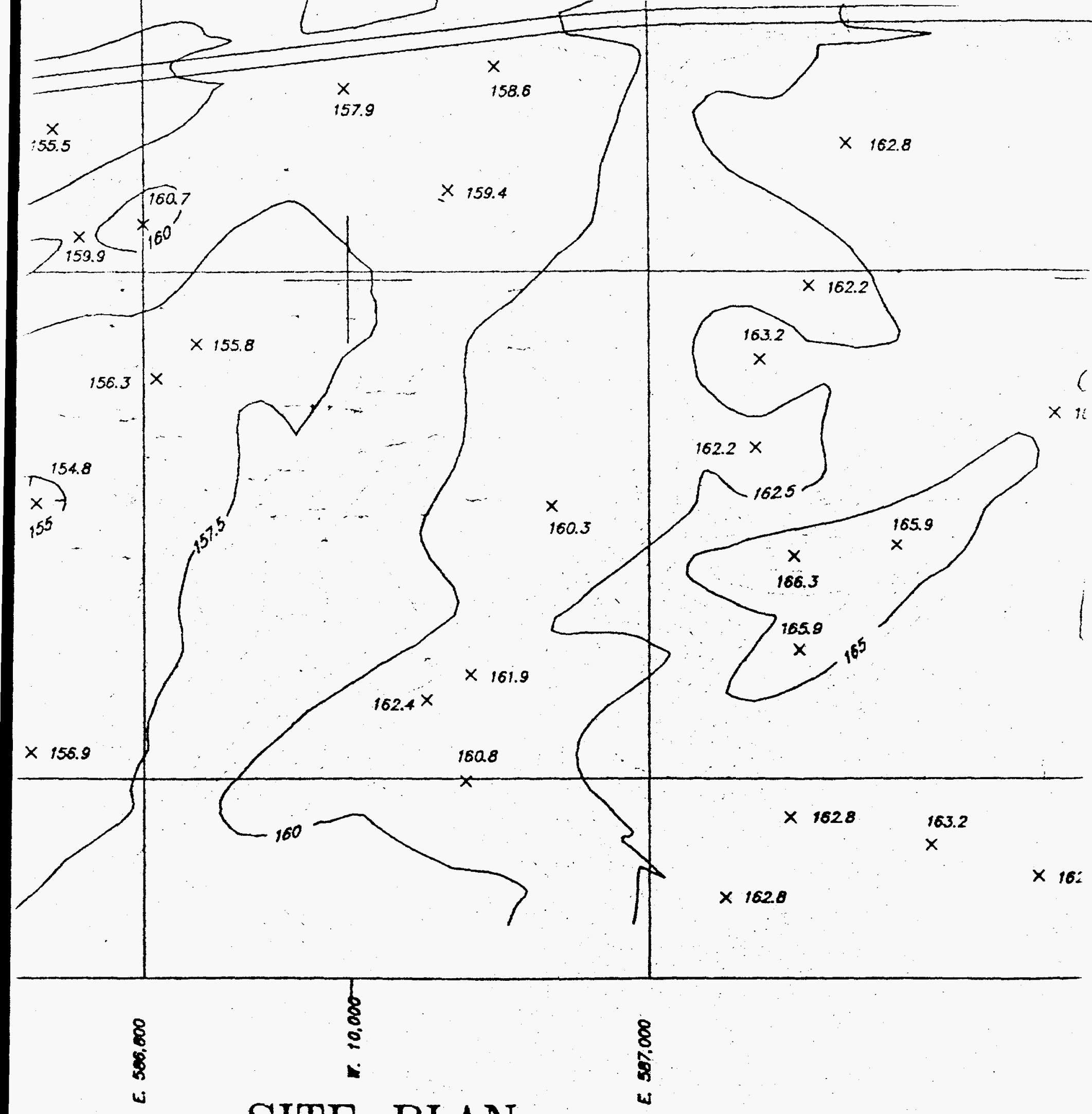

\section{SITE PLAN}

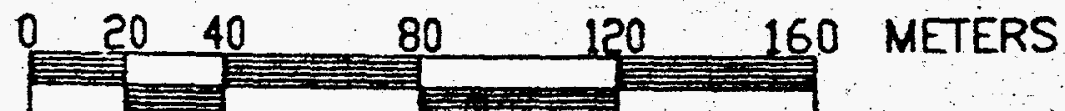

$\begin{array}{lllllllll}0 & 100 & 200 & 300 & 400 \quad 500 \quad 750 & 7000 & \text { FEET }\end{array}$ 1 


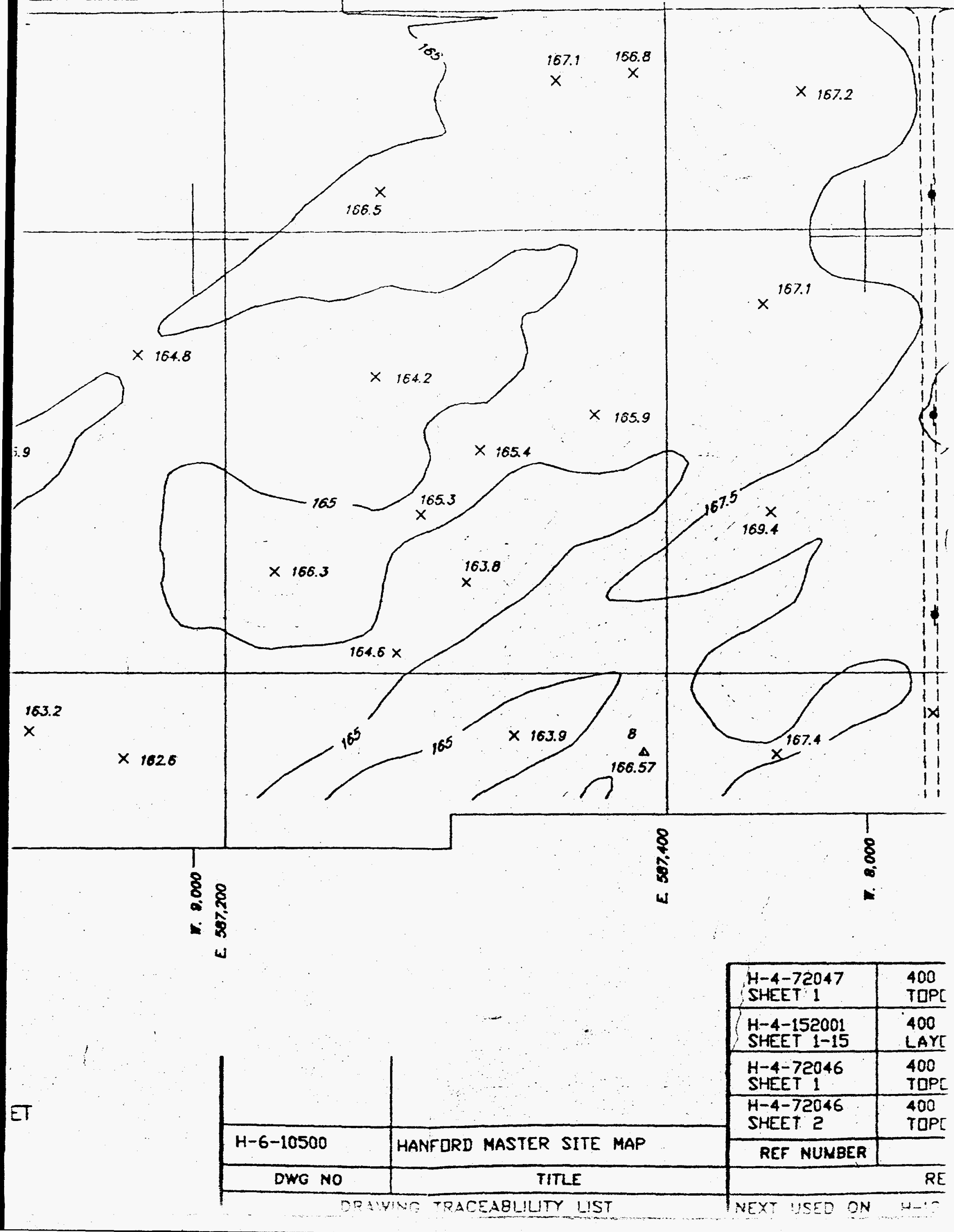




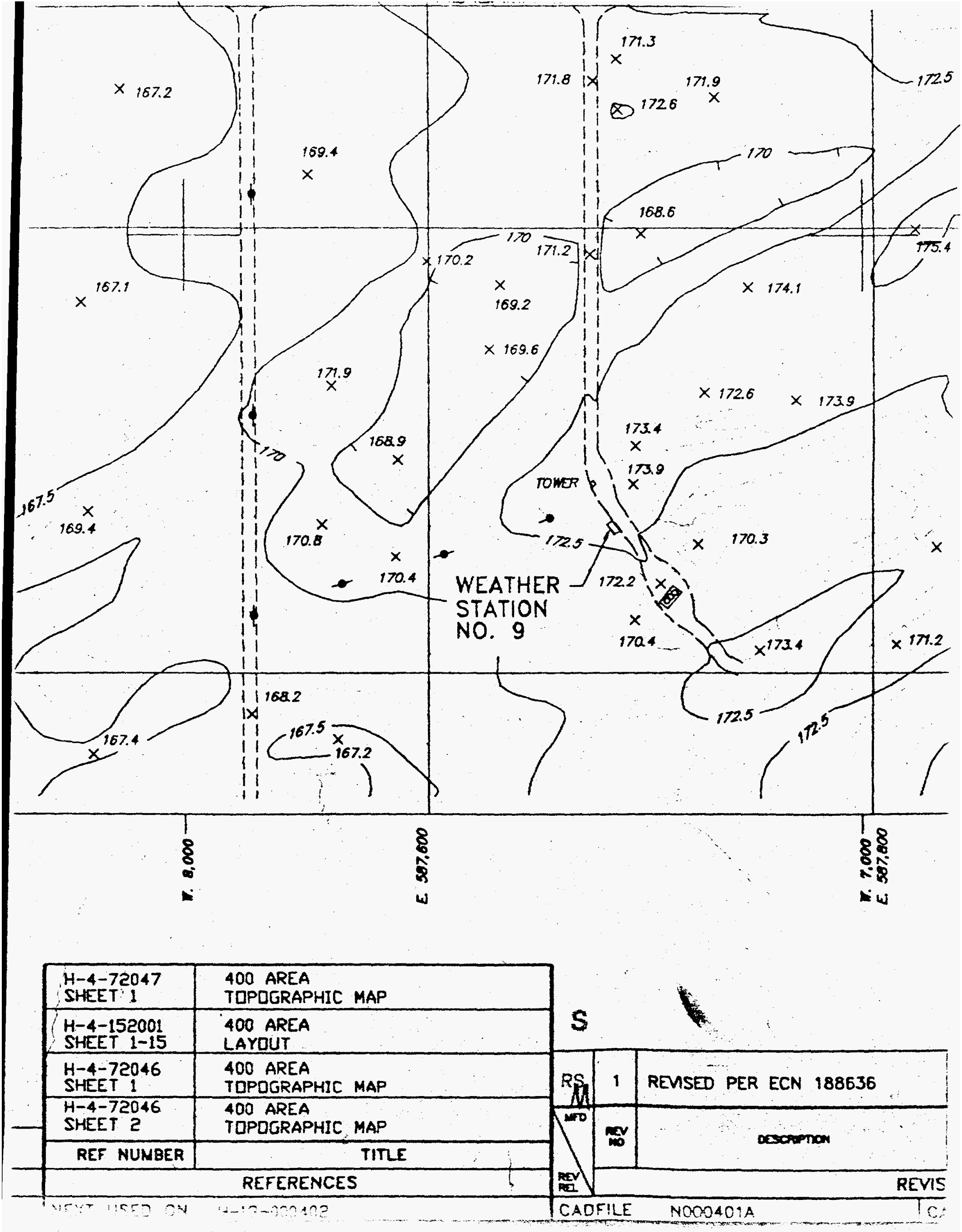




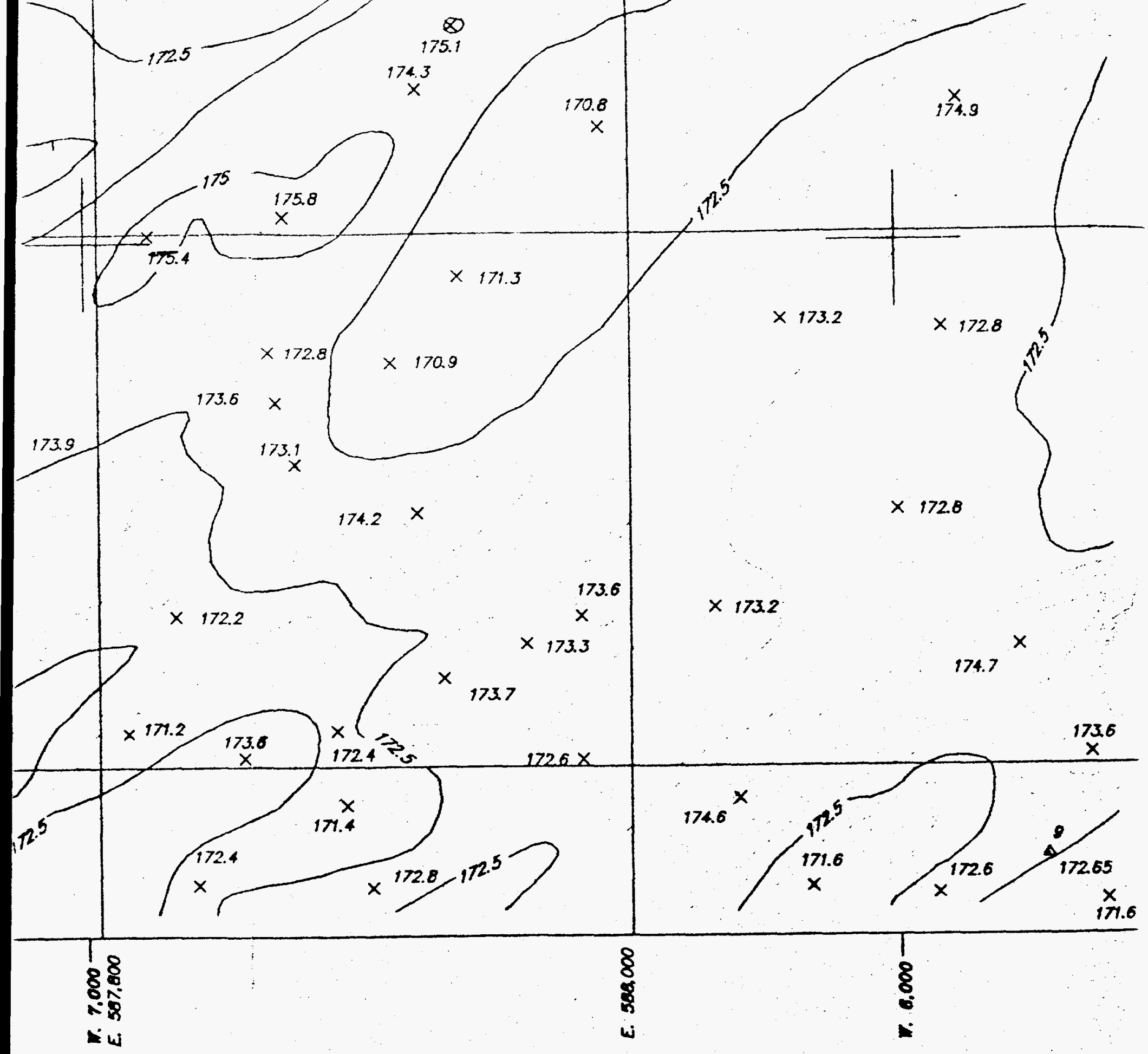

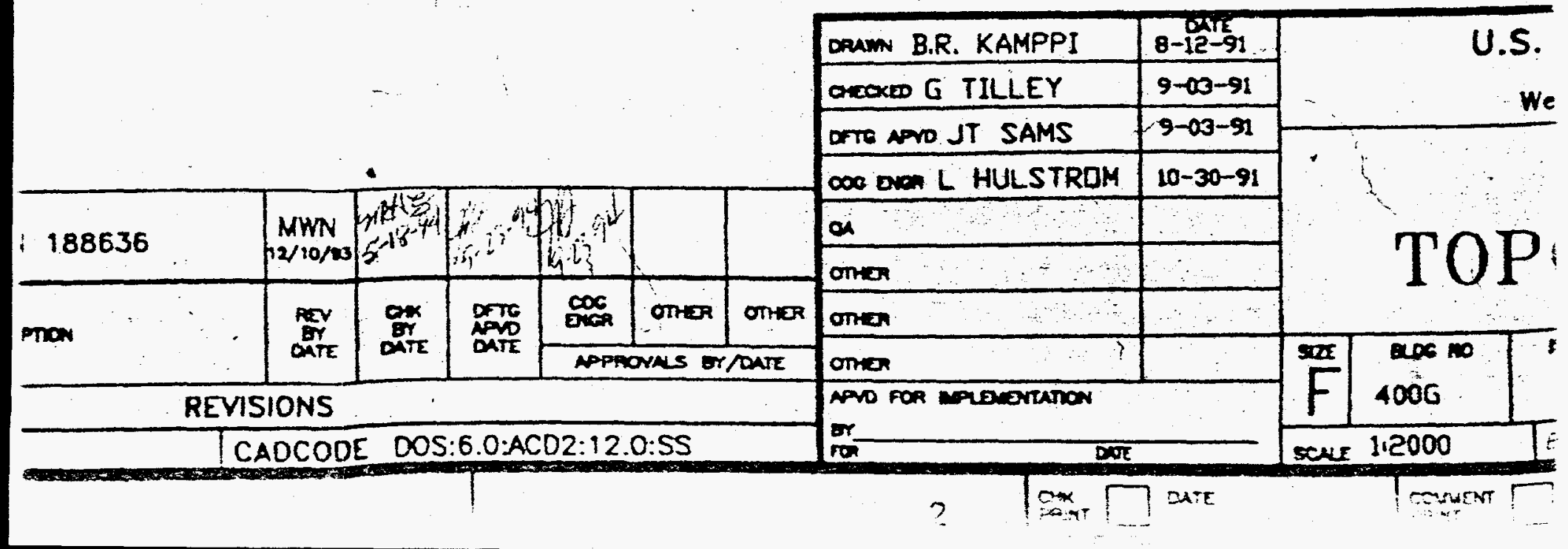


DOE/RL-94-89, Rev. 2

$01 / 96$

\section{ATTACHMENT H}

\section{WELL LOGS}

(SECTION H - ITEM 4) 
D0E/RL-94-89, Rev. 2

$01 / 96$

This page intentionally left blank. 



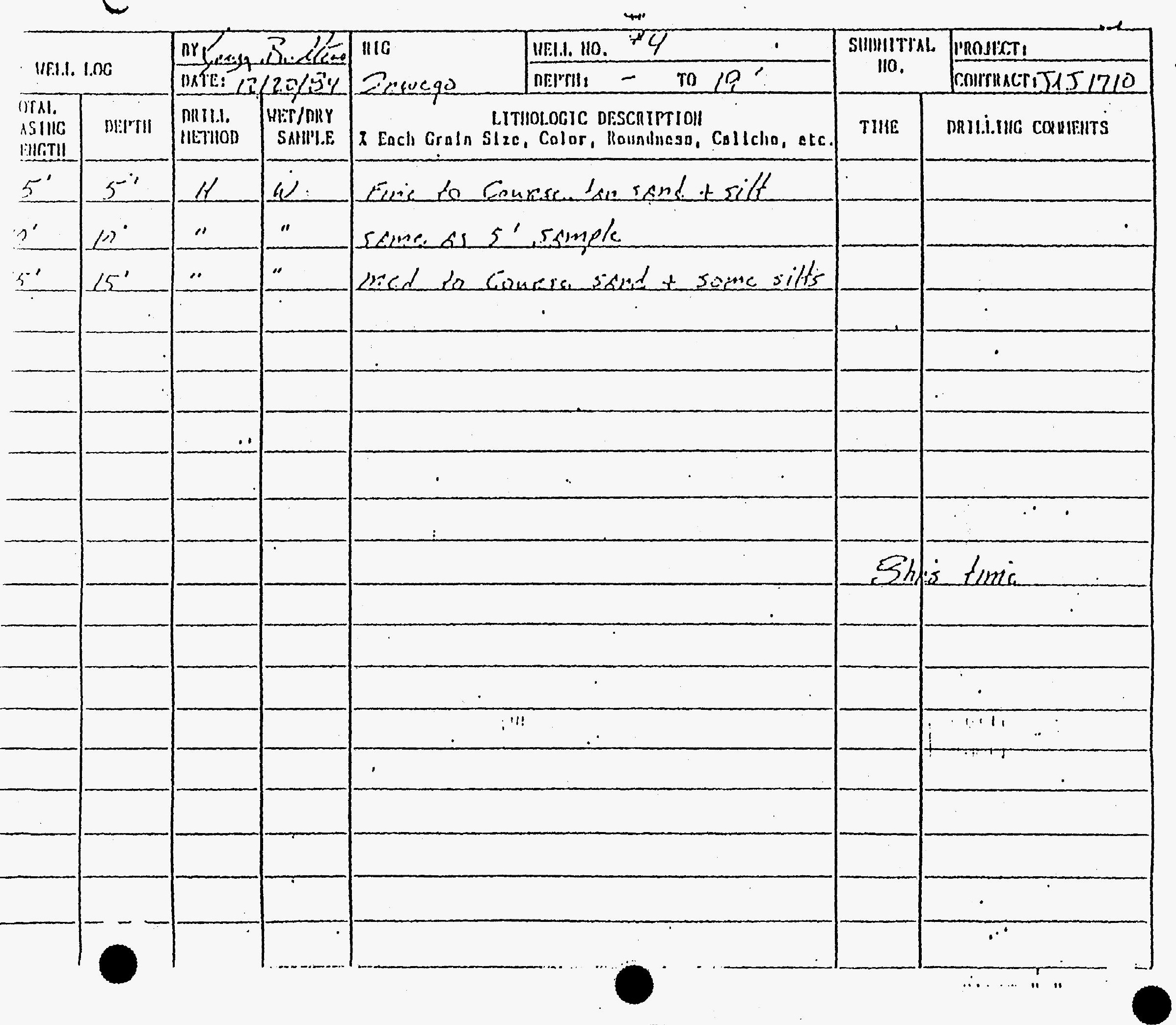




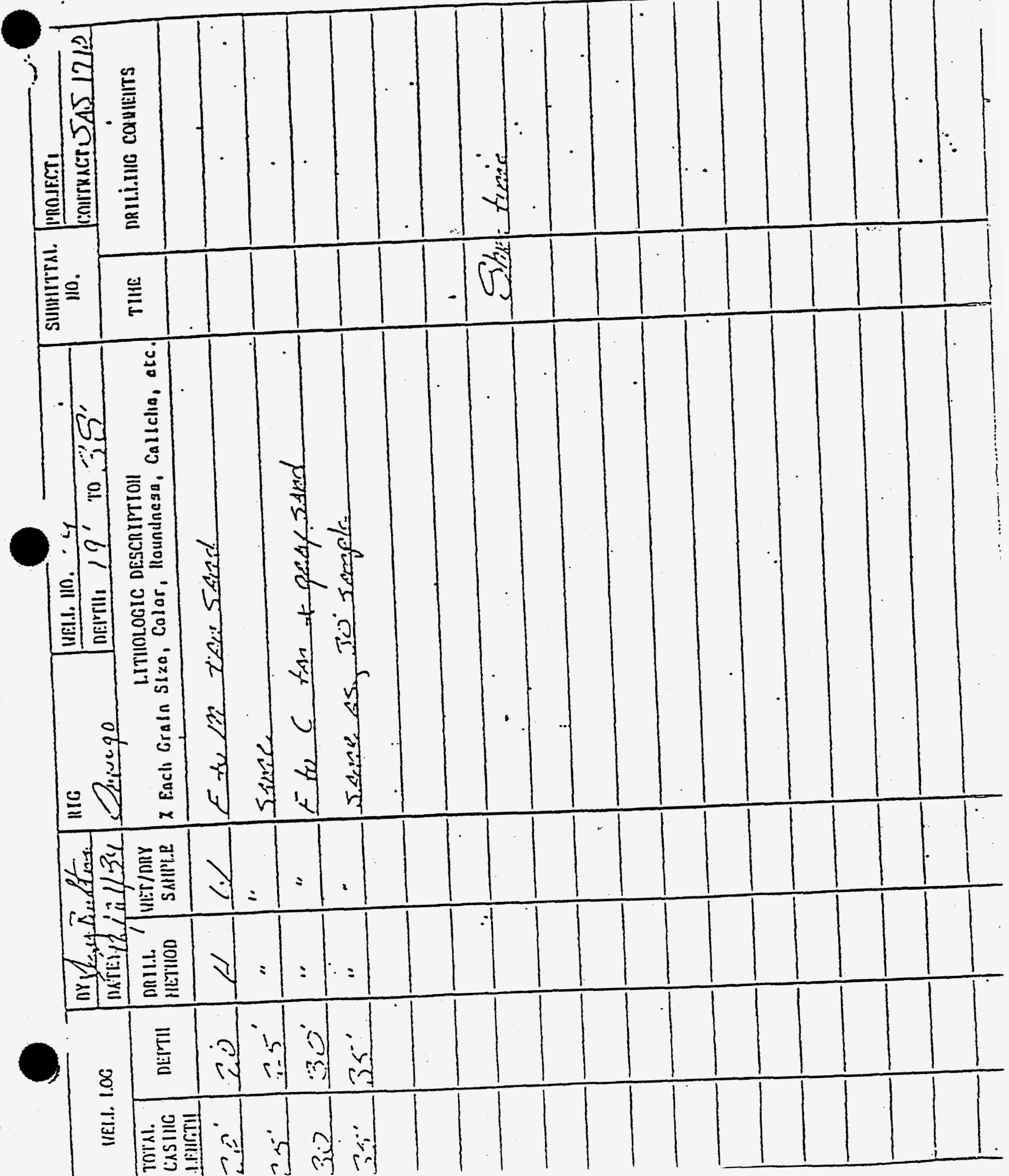




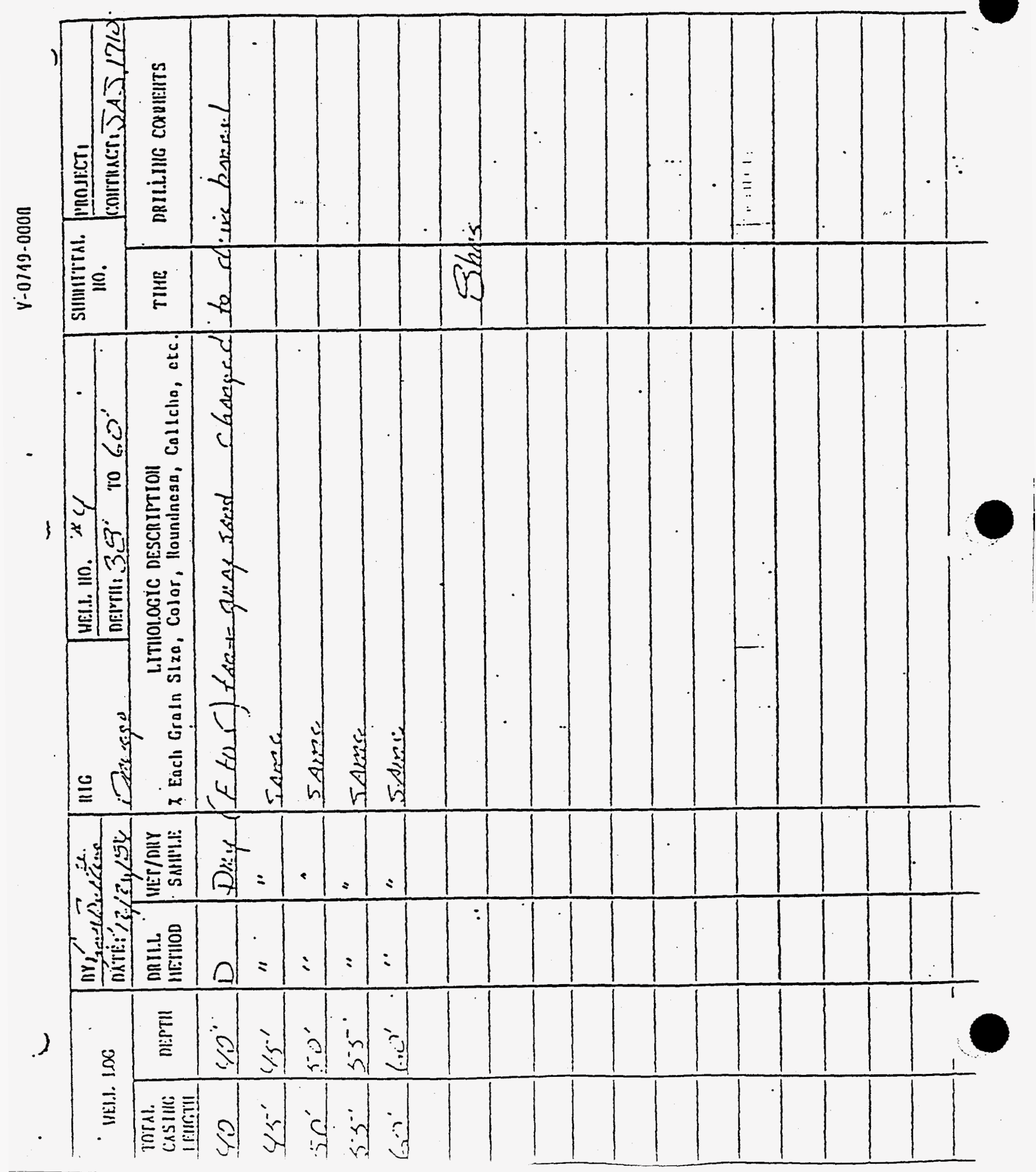




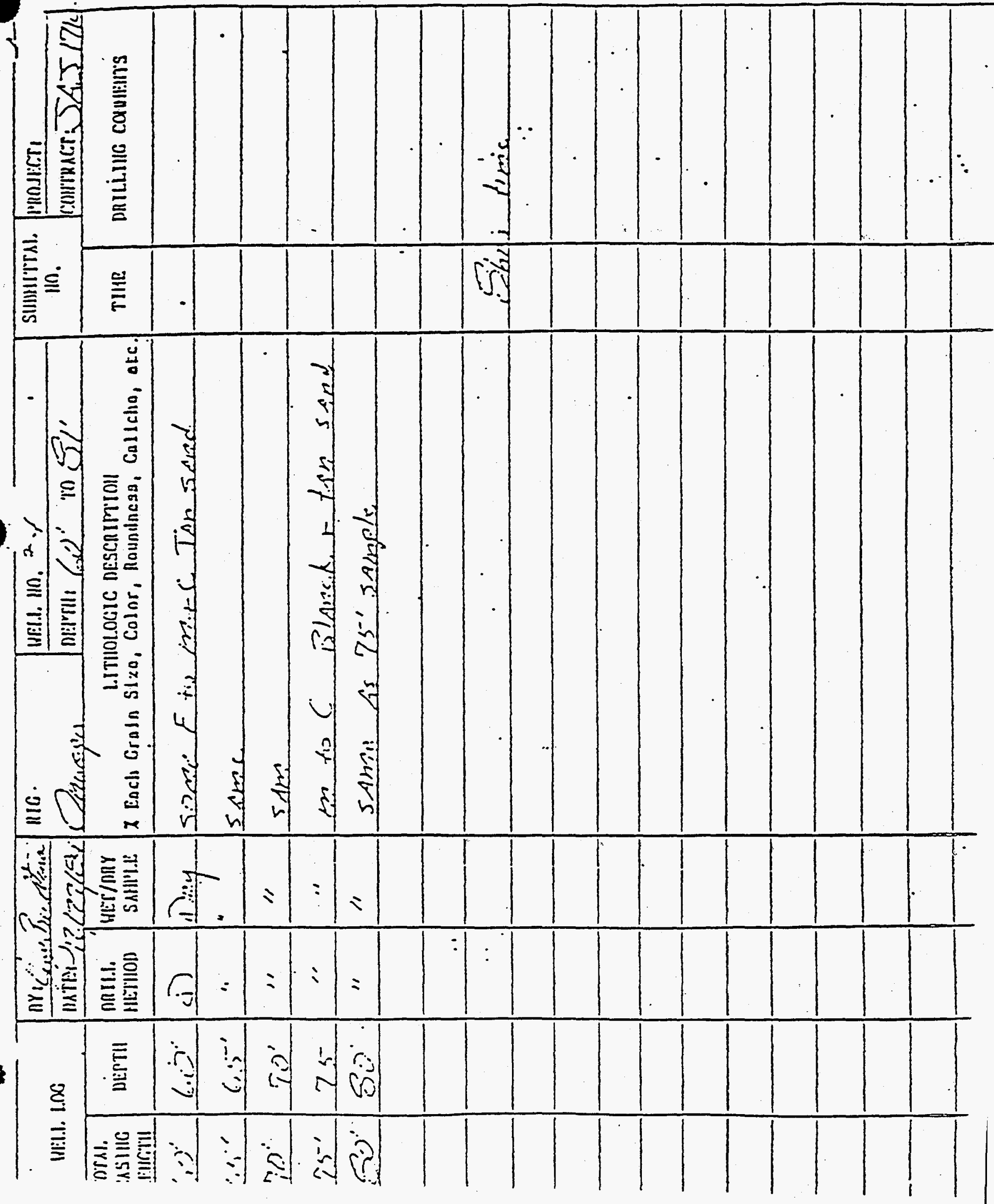




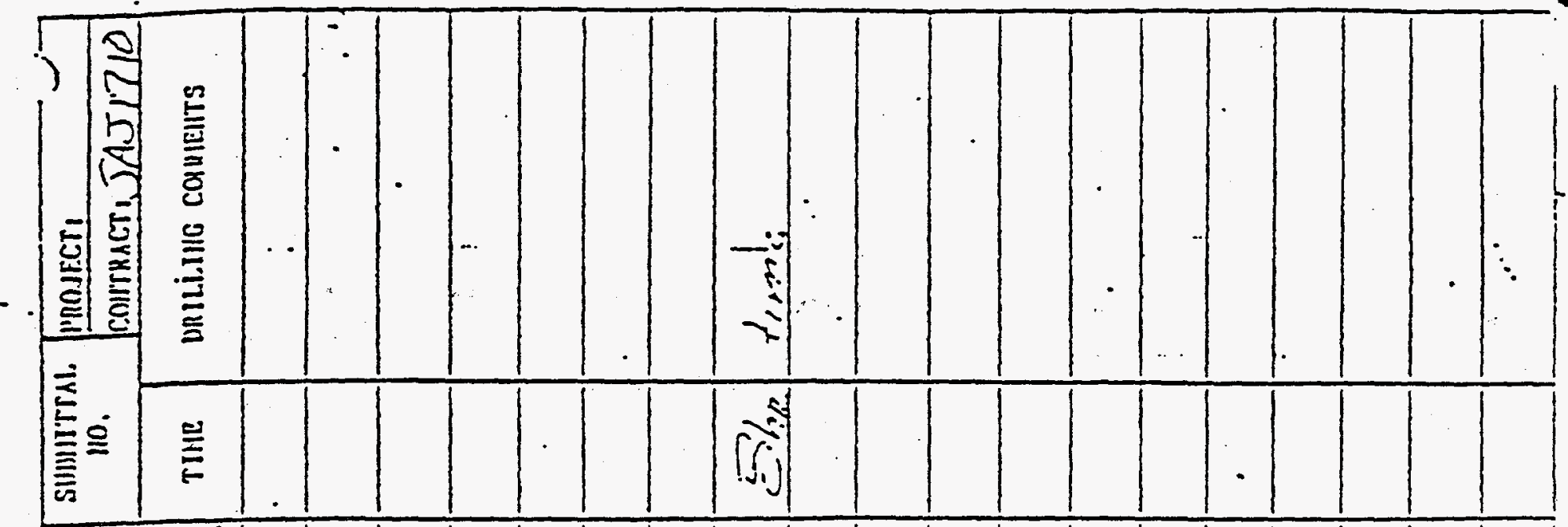

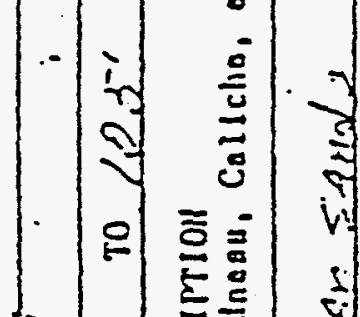

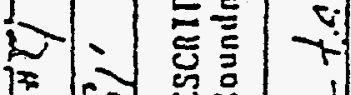

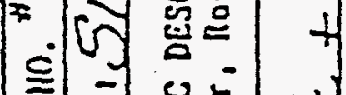

言

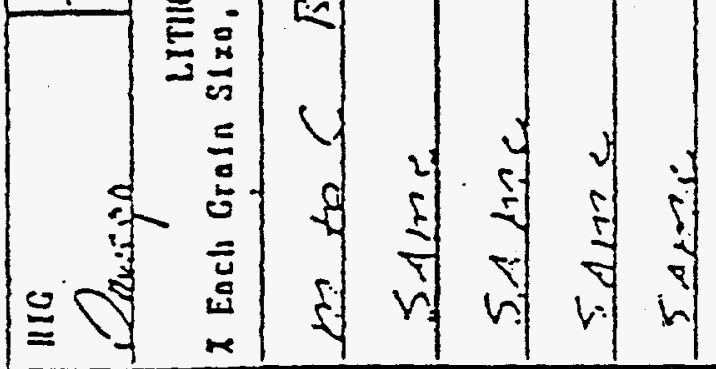

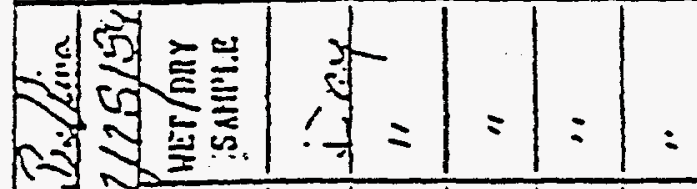

तो

N늘 을

$=1$ 이인

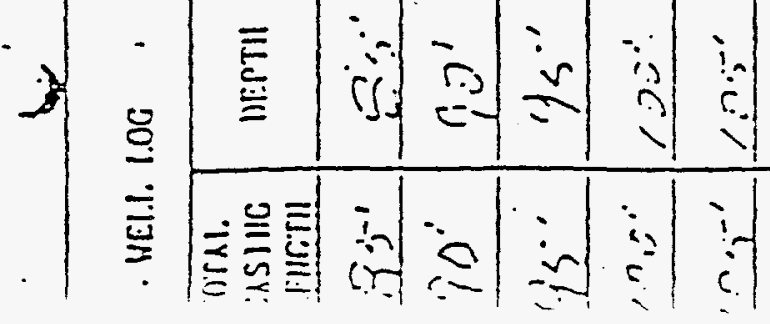





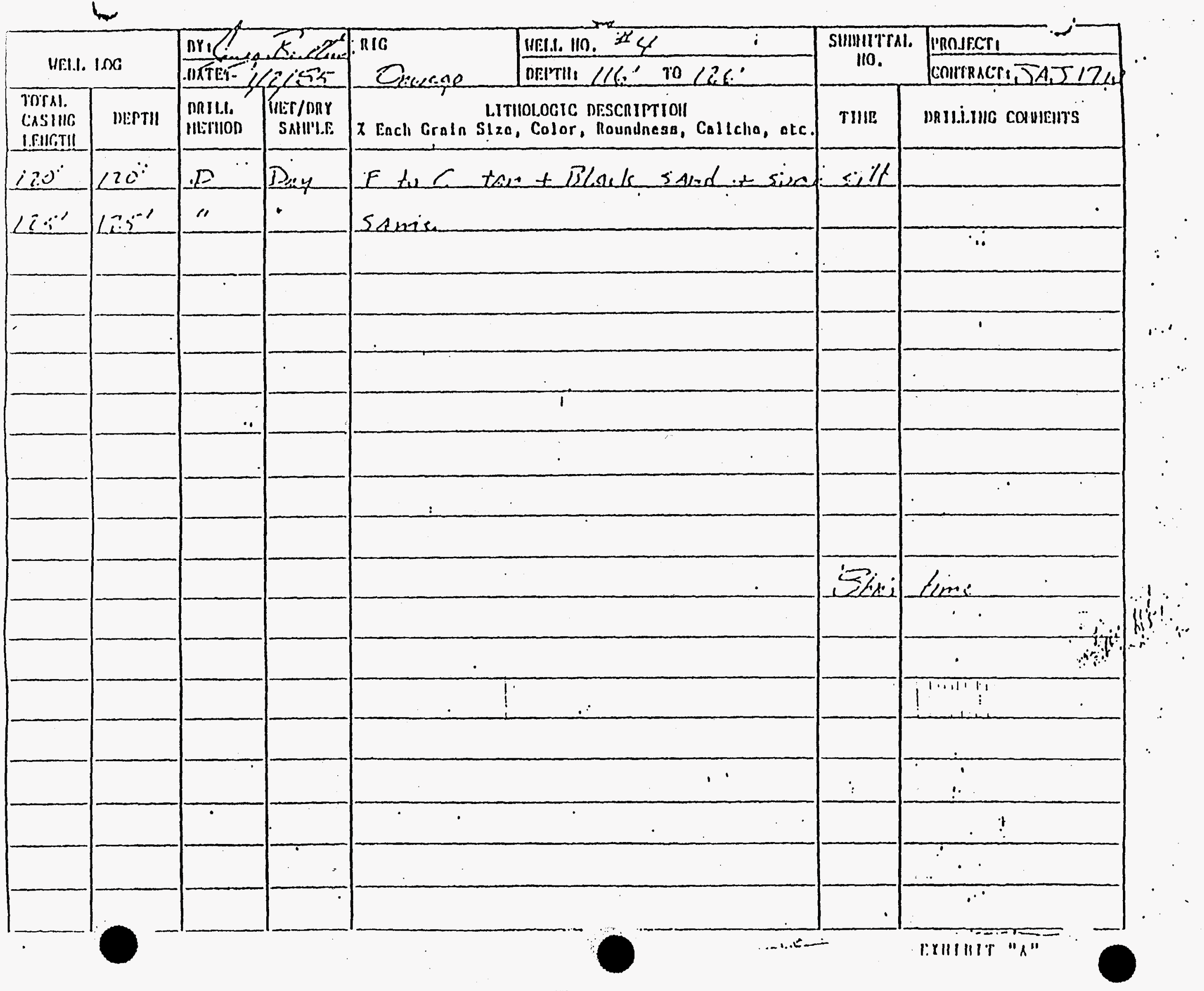


400 Area Secundary Couling Water Atrachment :H

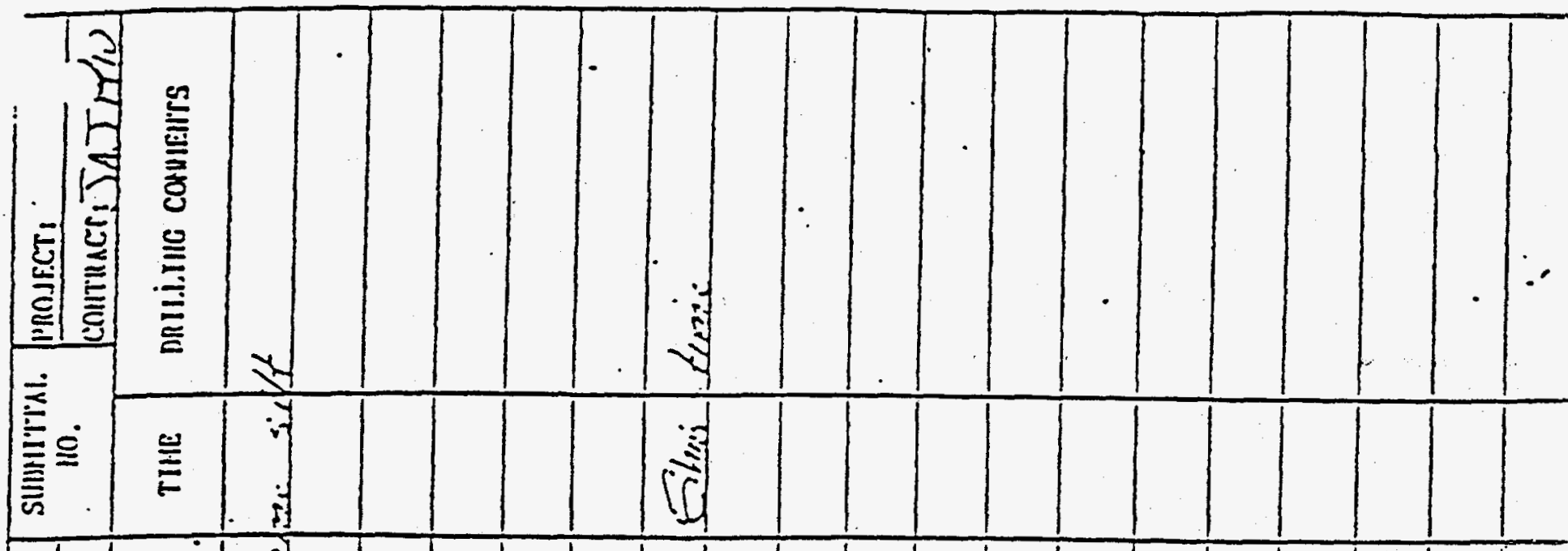

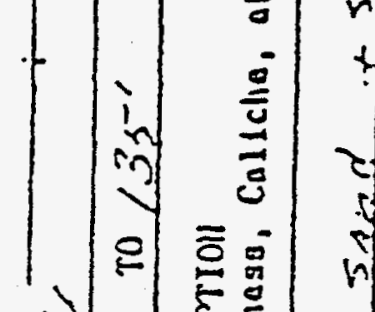

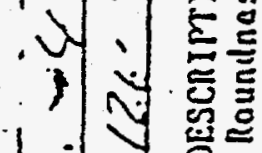

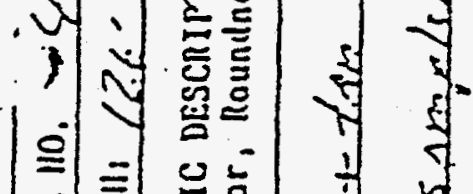

言离 范

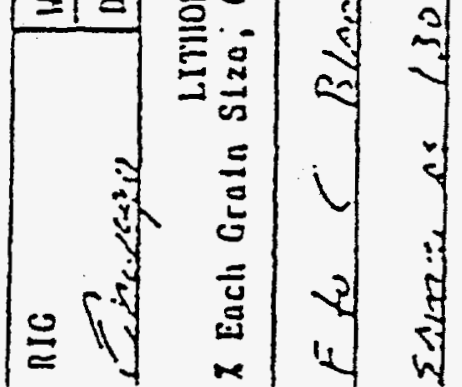

riy

125

:

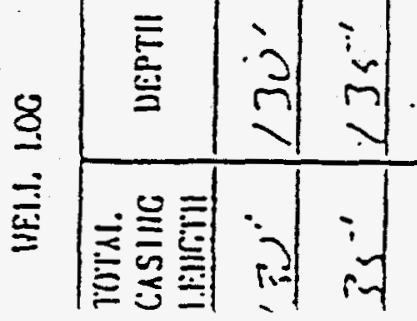




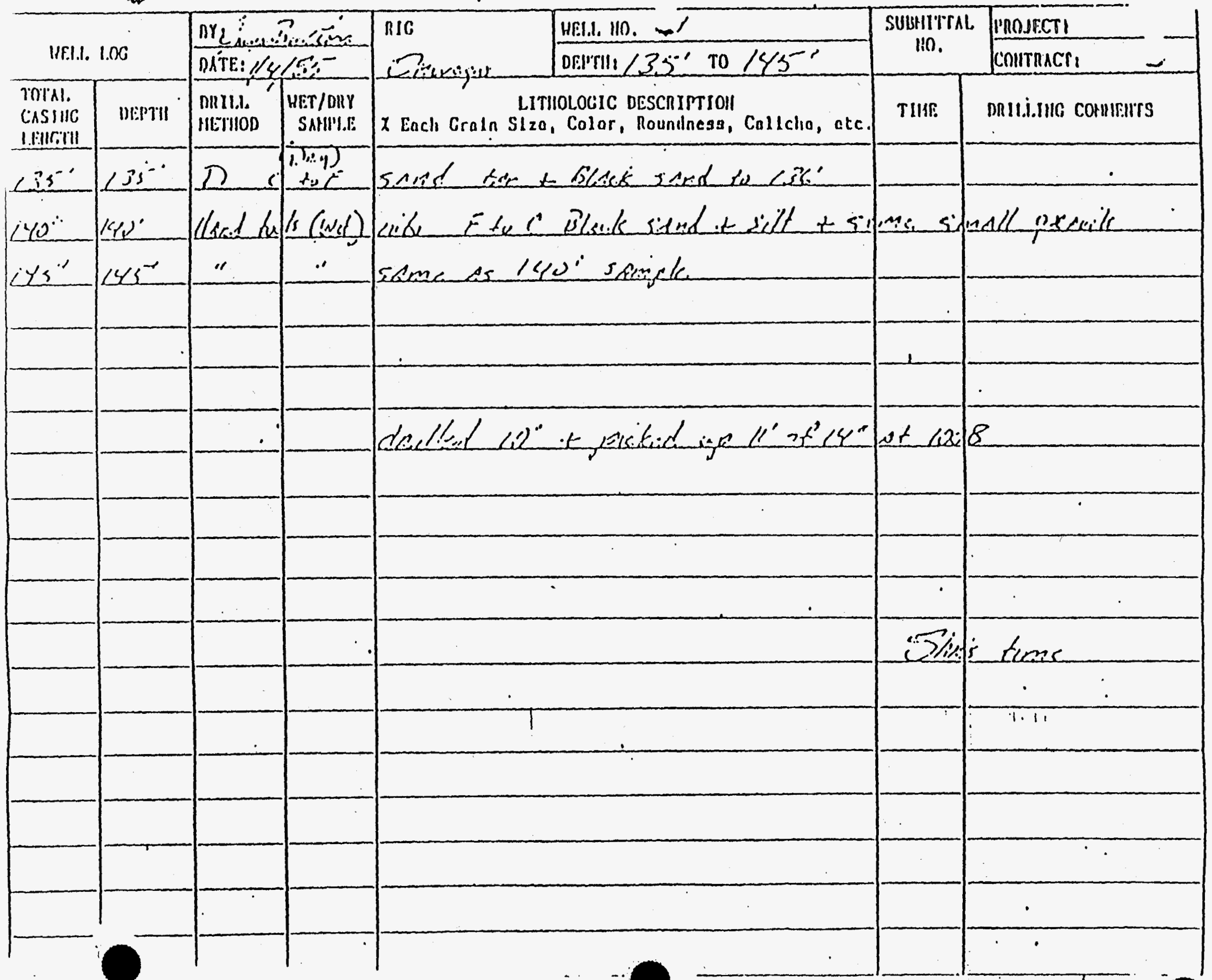





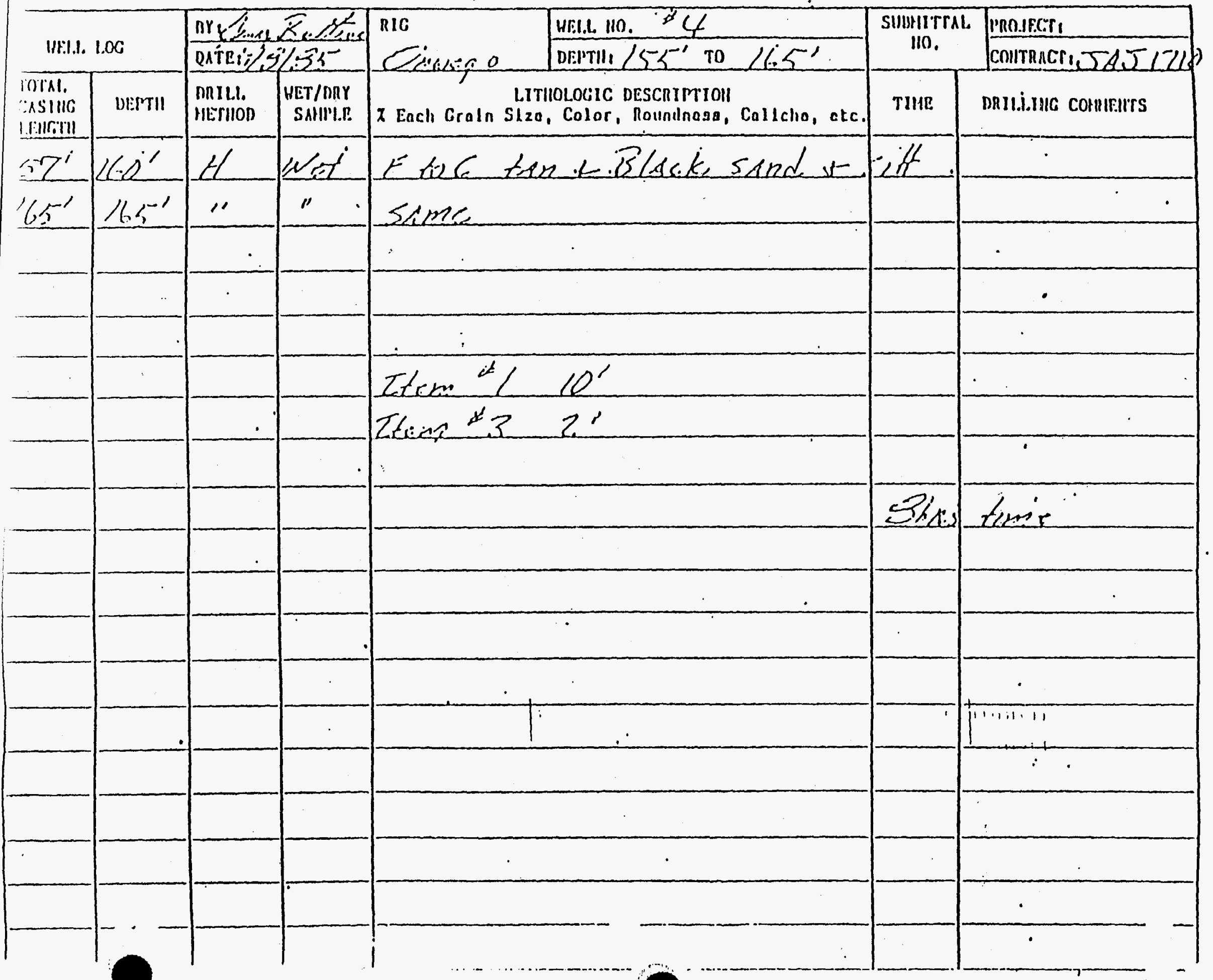


400 Area Secondary Cooling Water

Alischmen it.

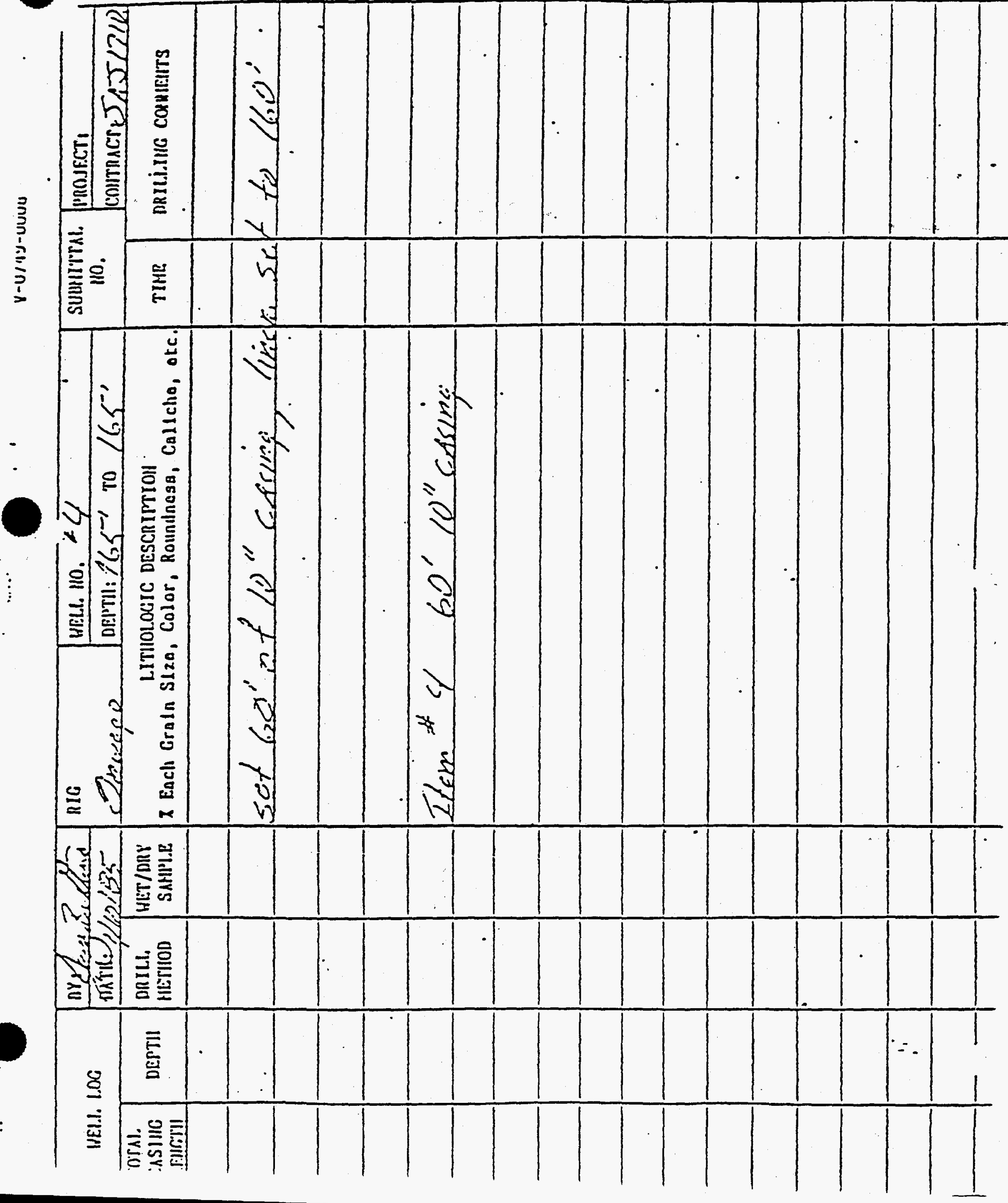




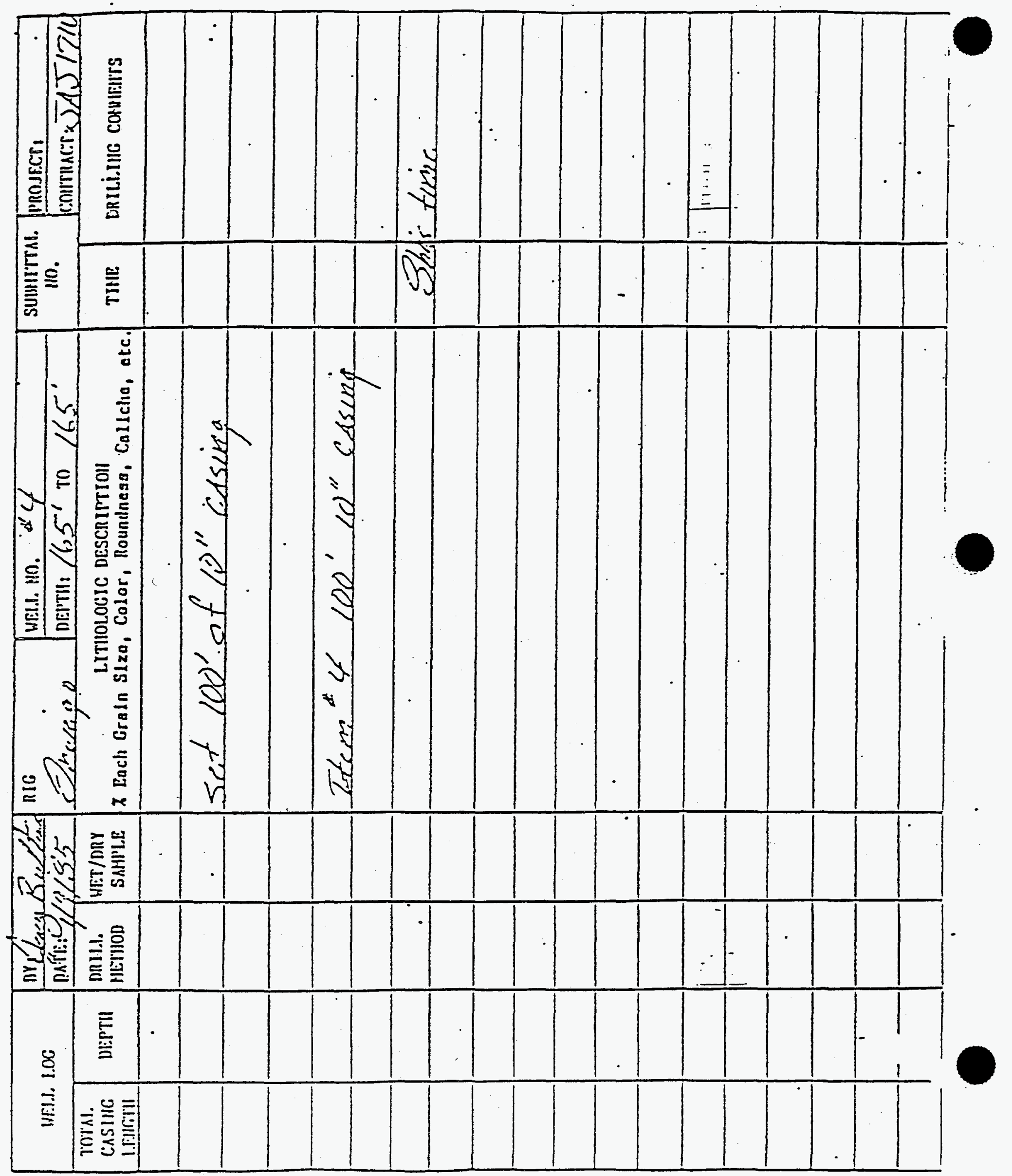




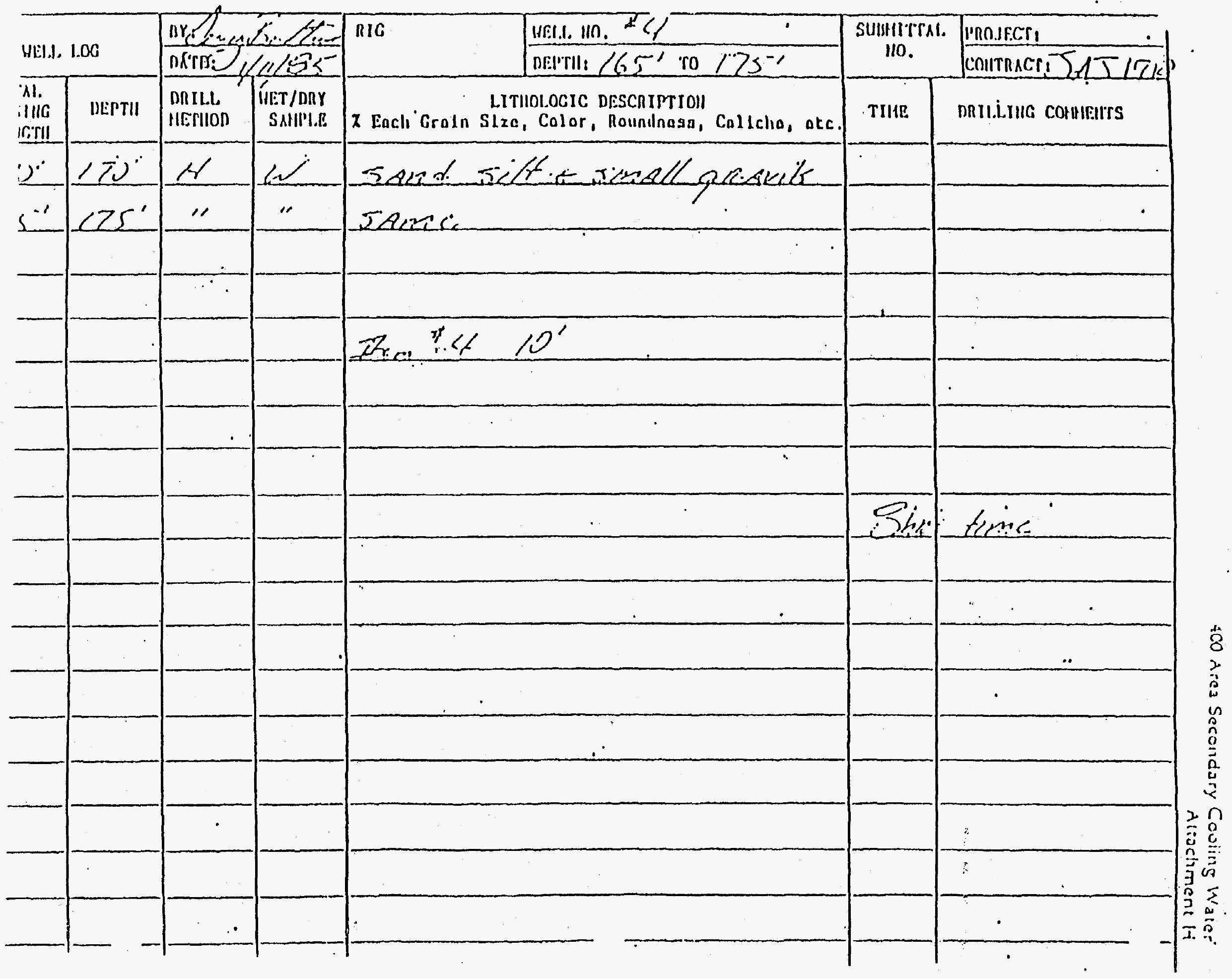




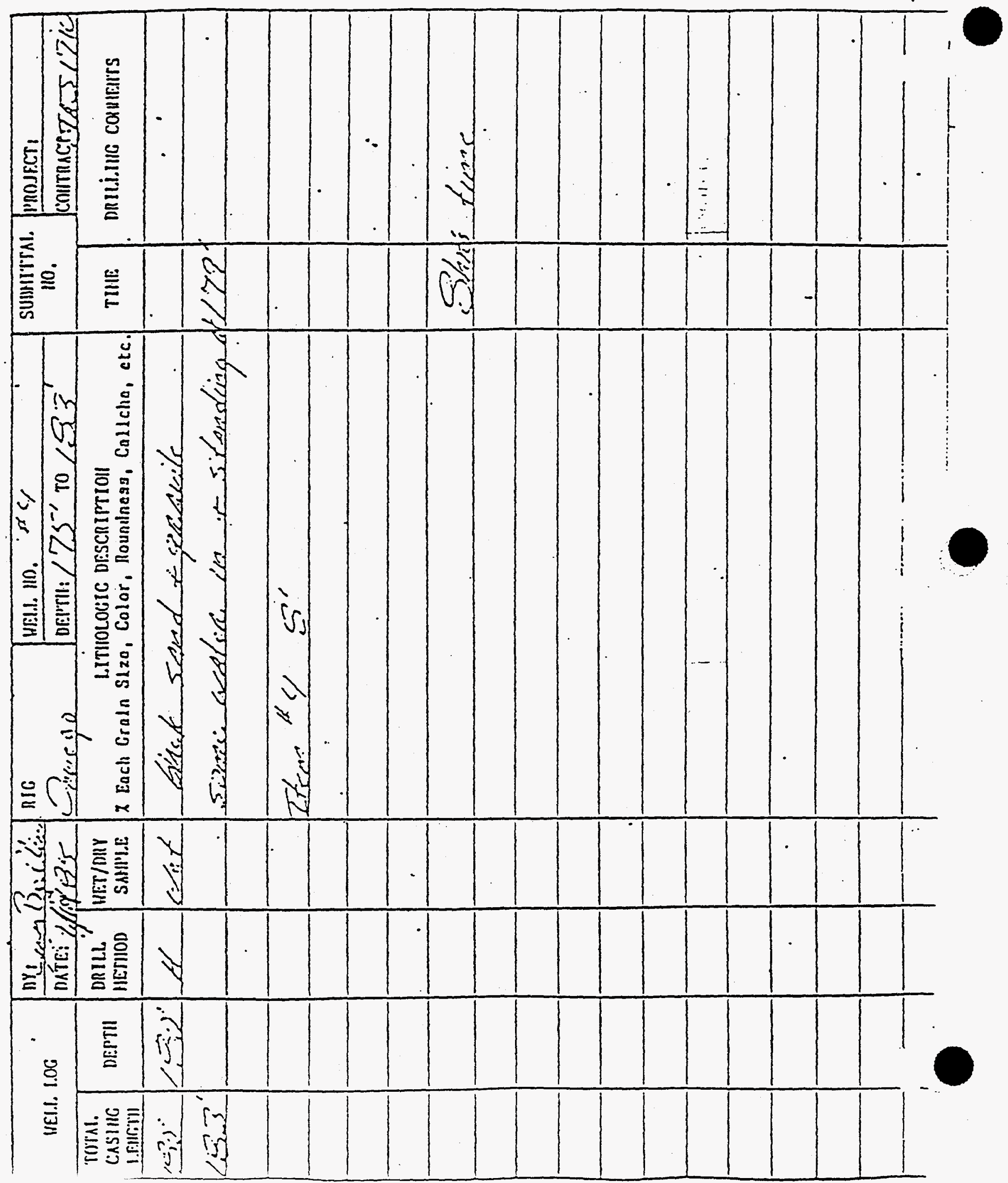




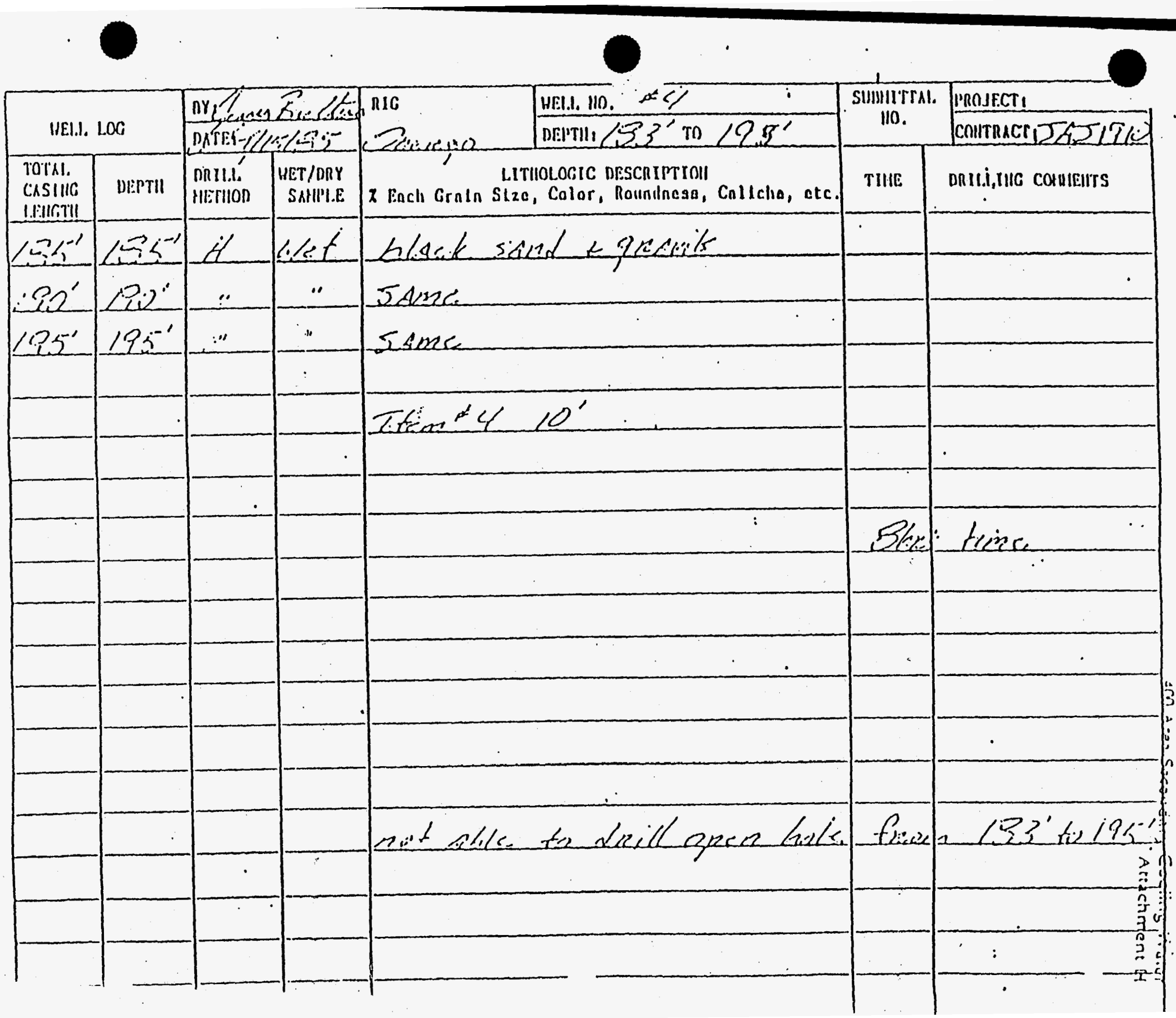




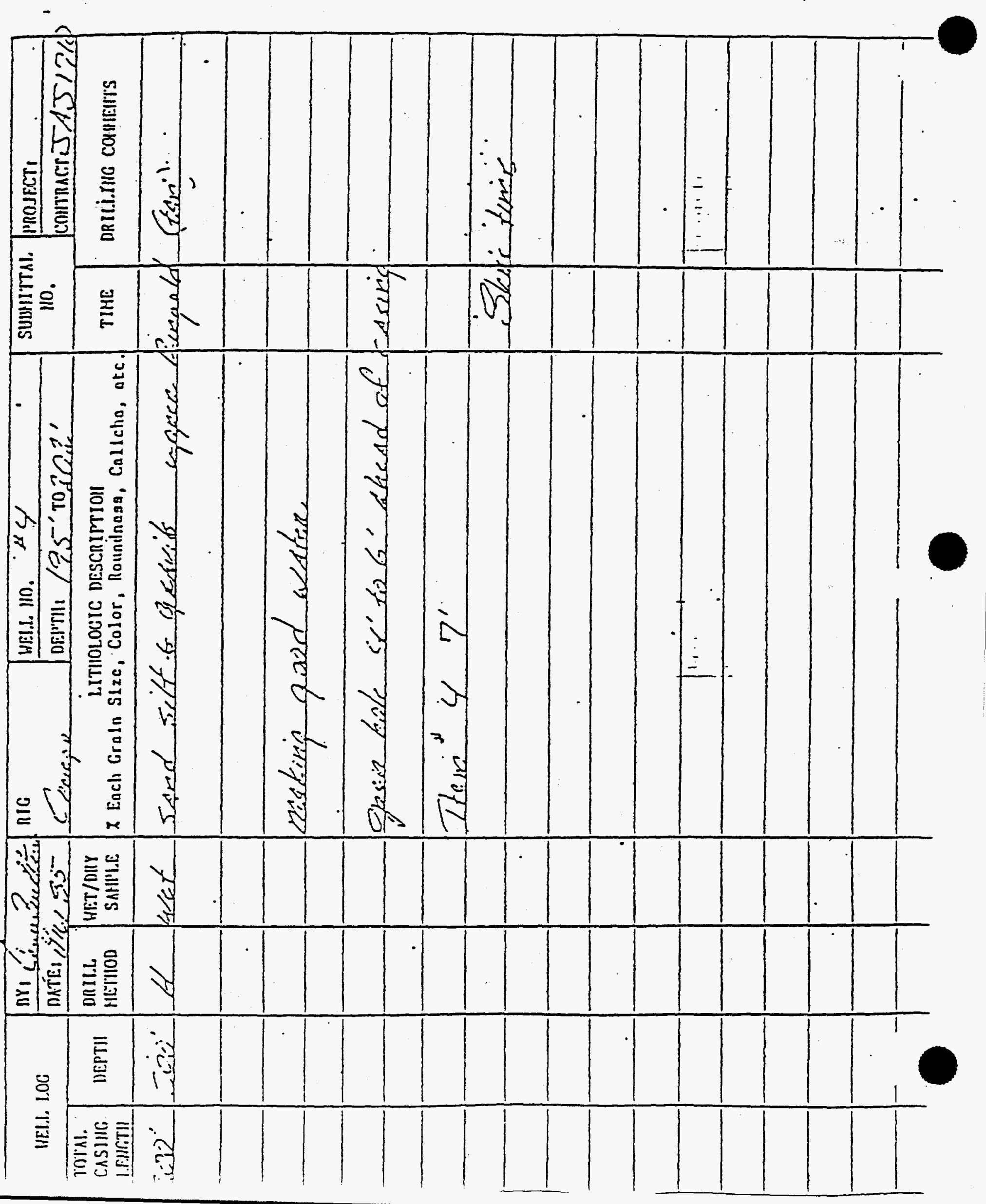




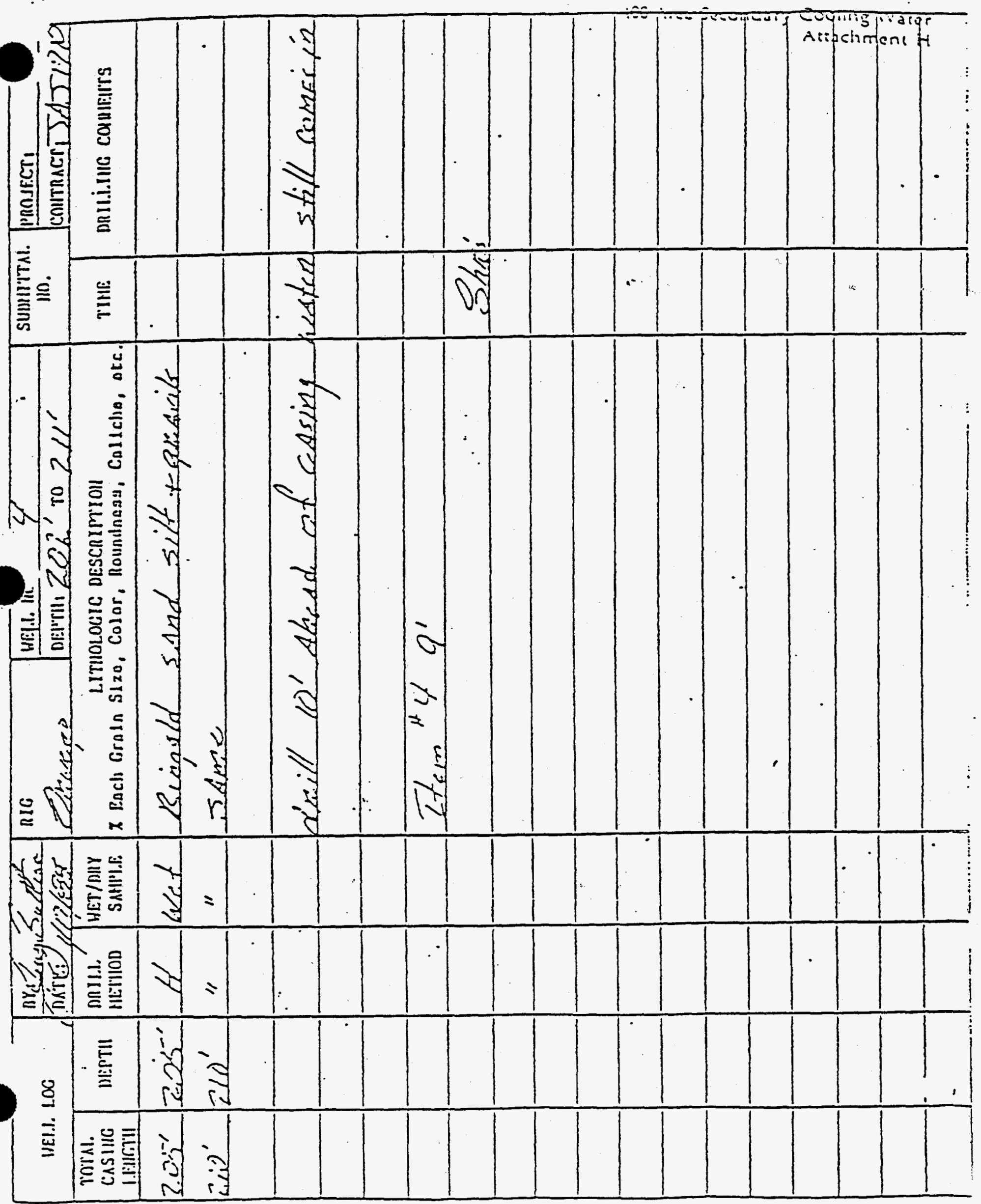



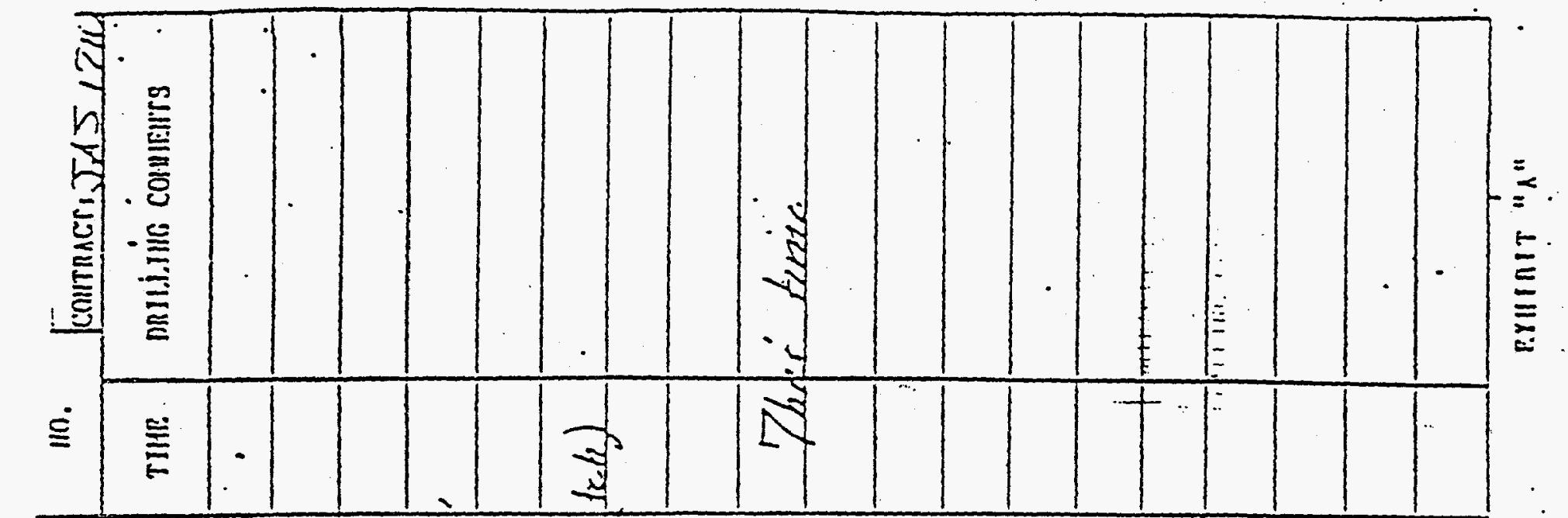
iCO diea Secondary Cooling Nater Altachment ta

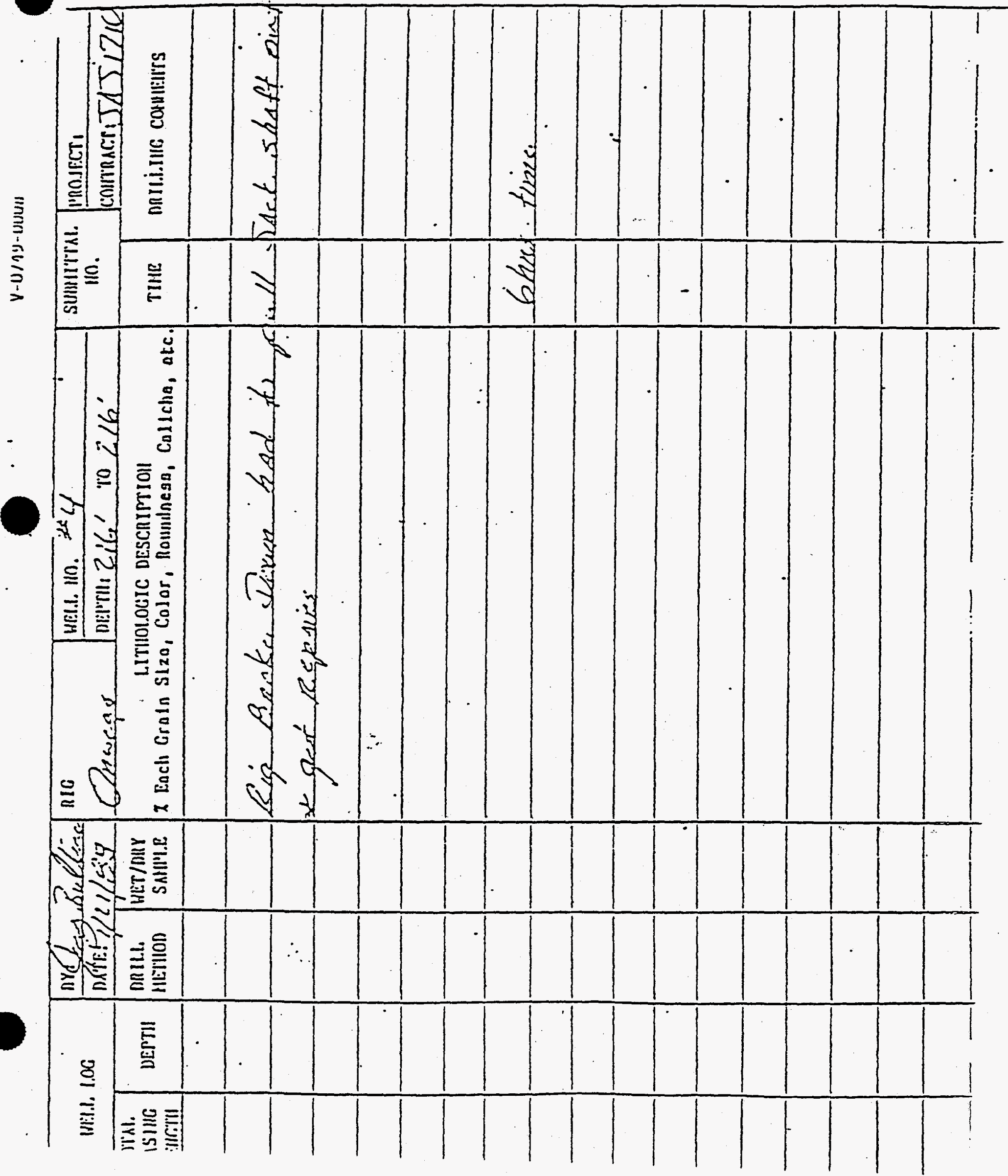




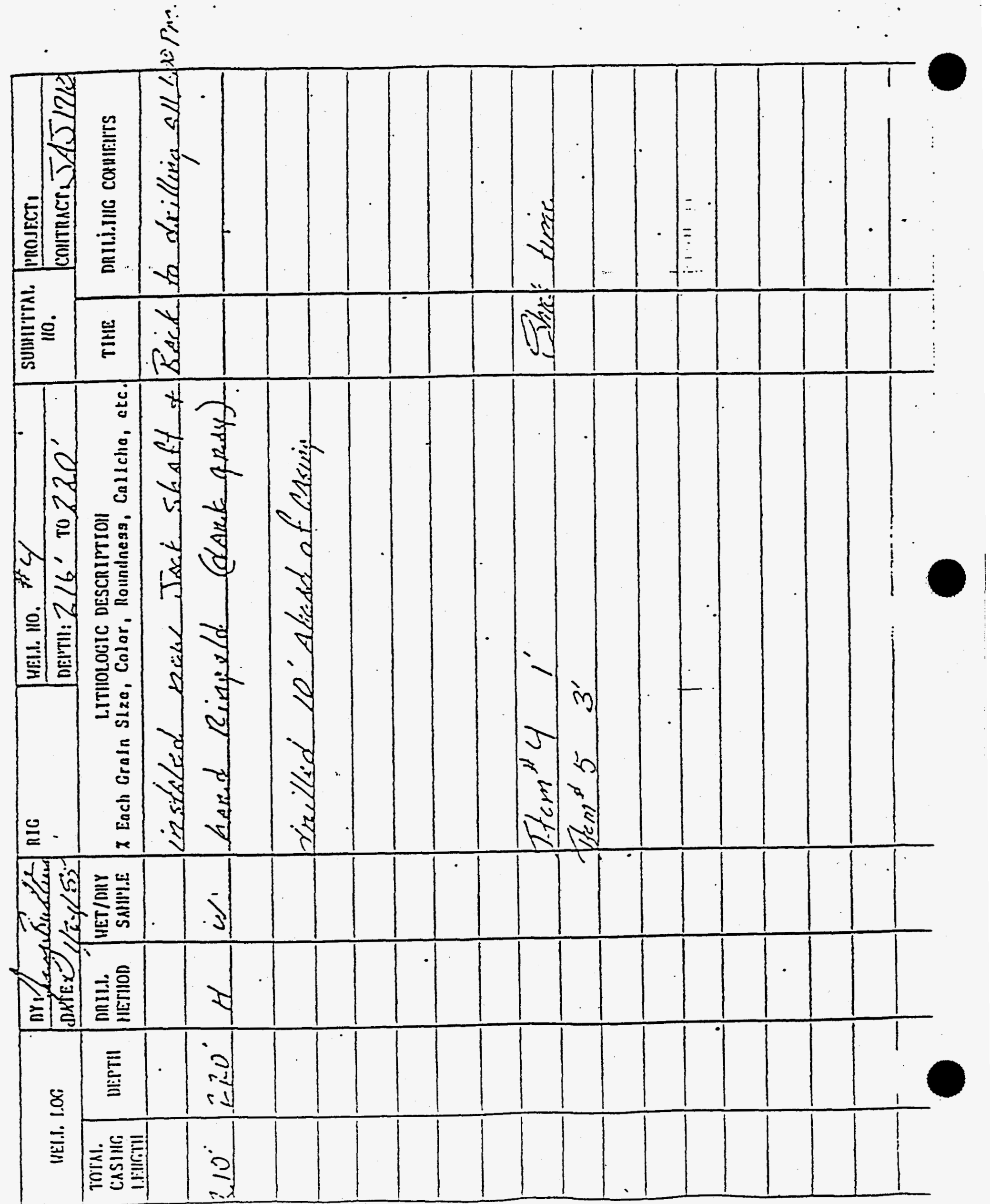


:CO Arez Secondary Cooling Water Atiachment H.

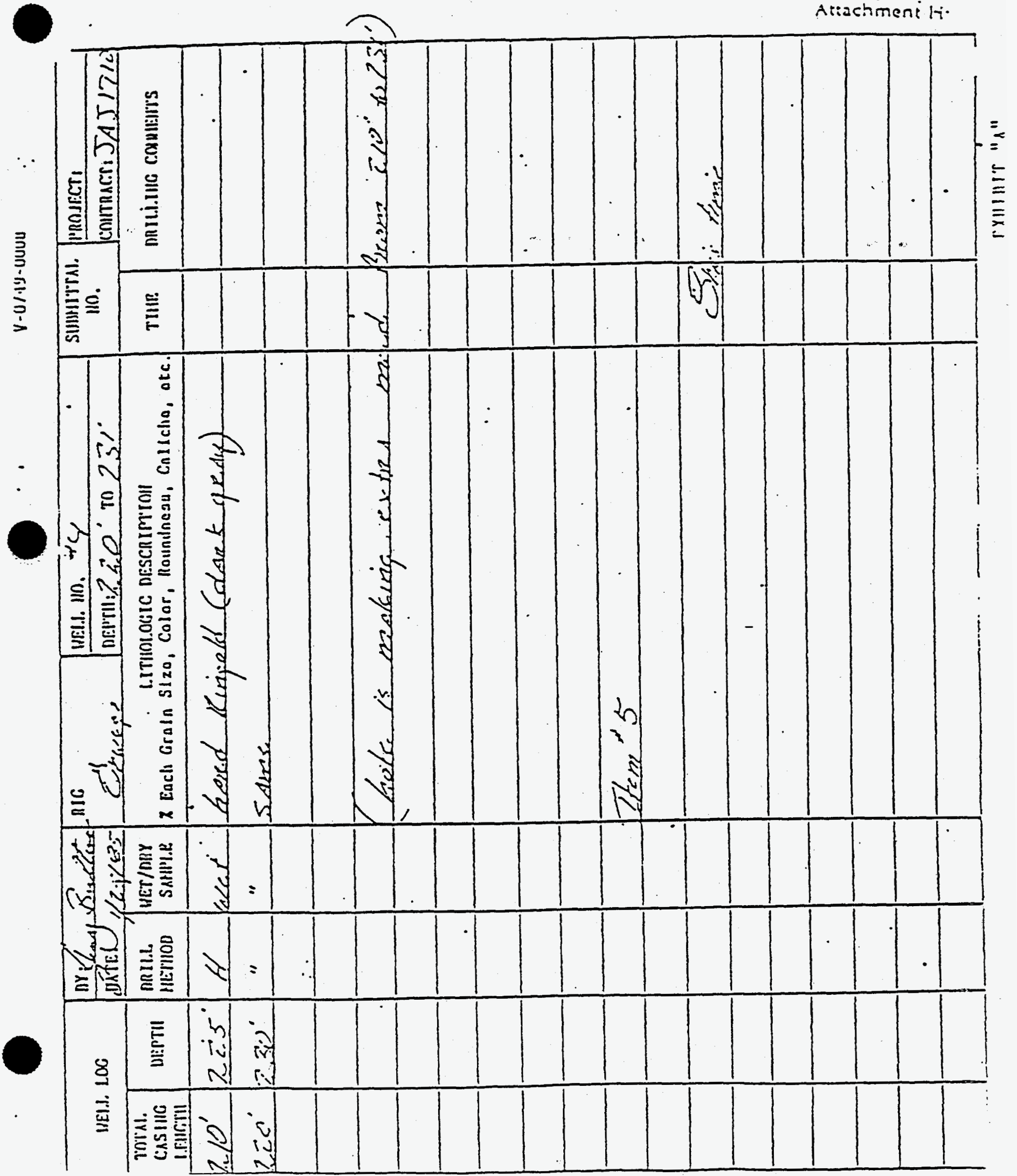


¿CO tirea Sesoneary Coving Water Aisachmeric H

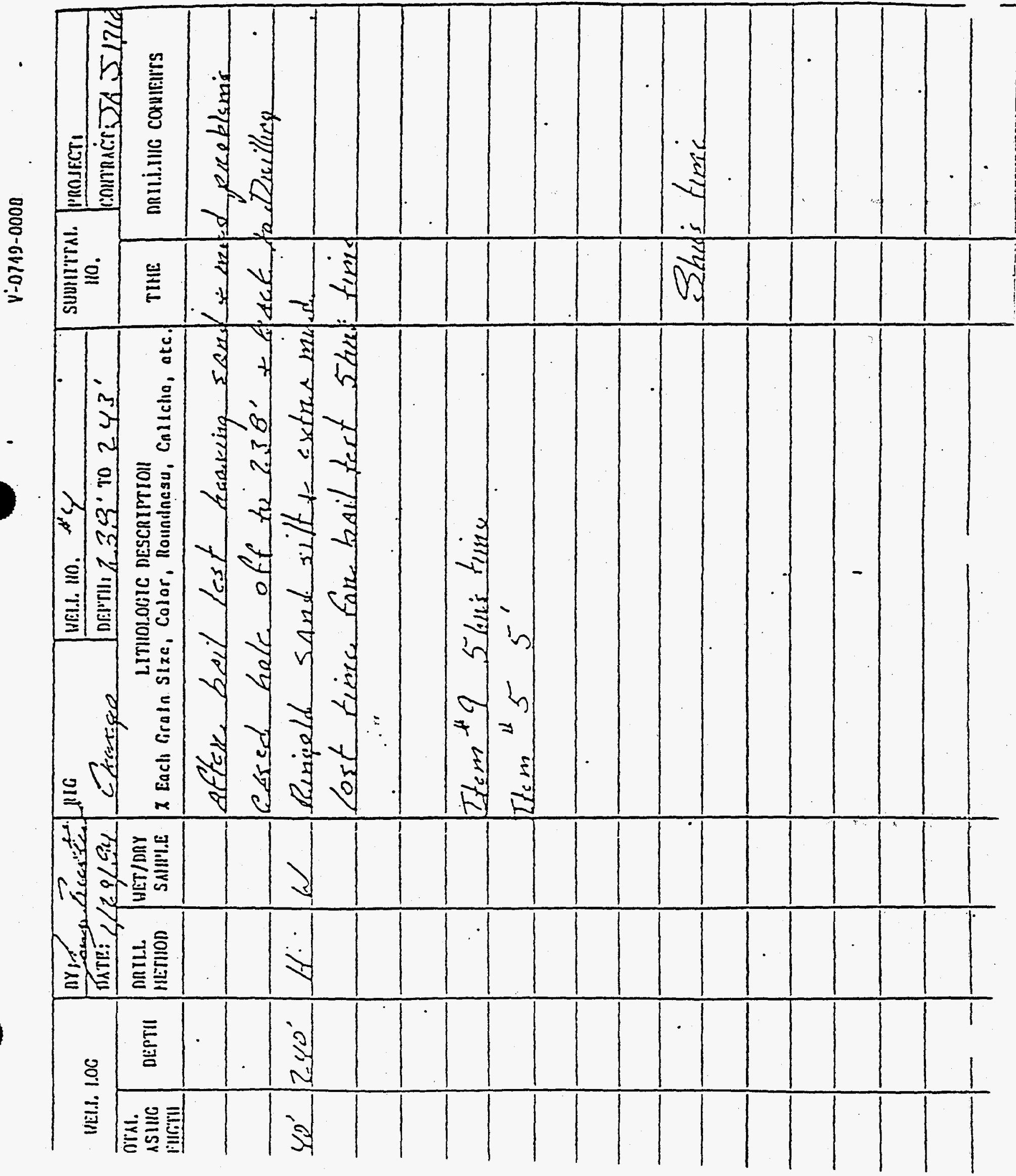





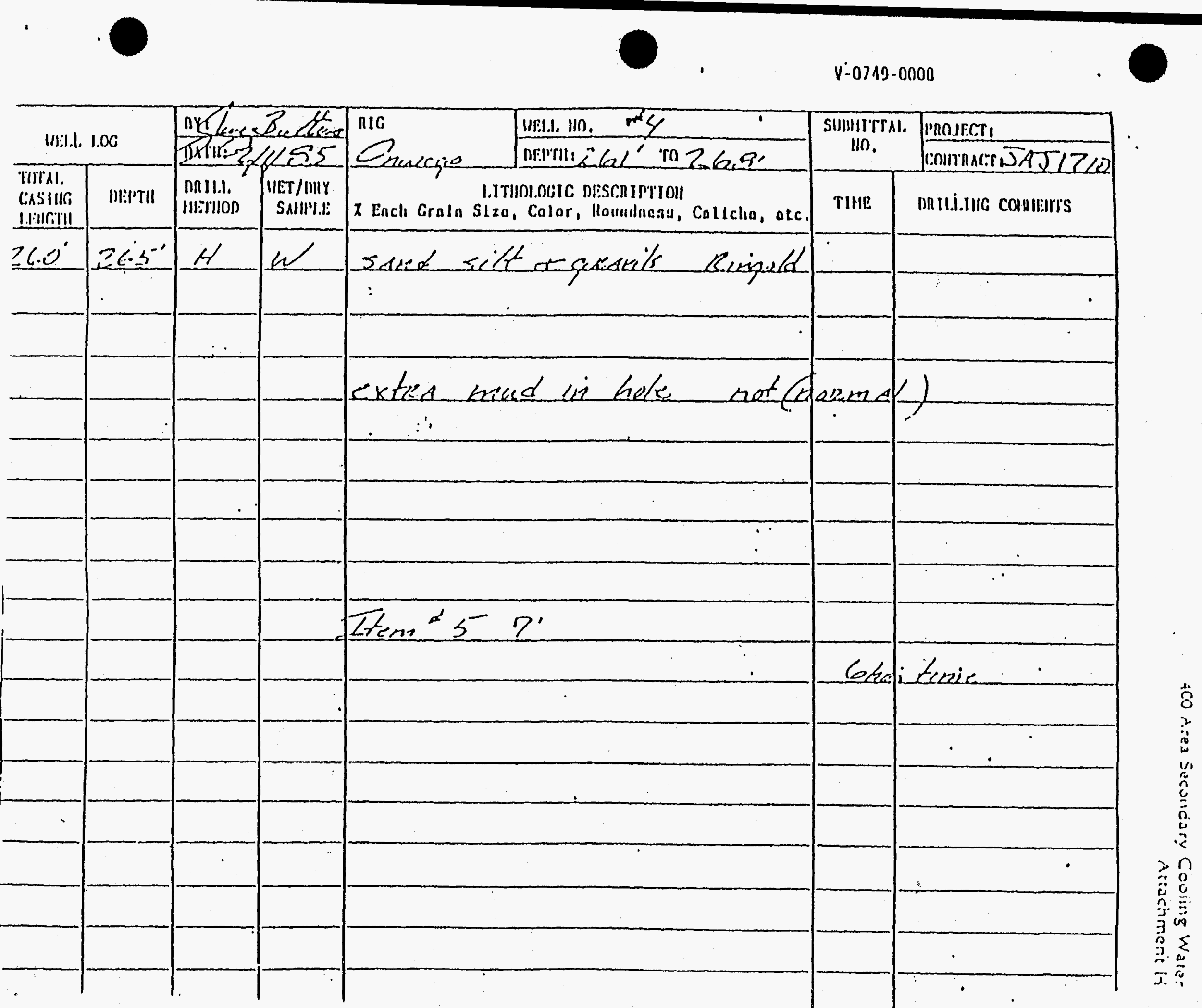





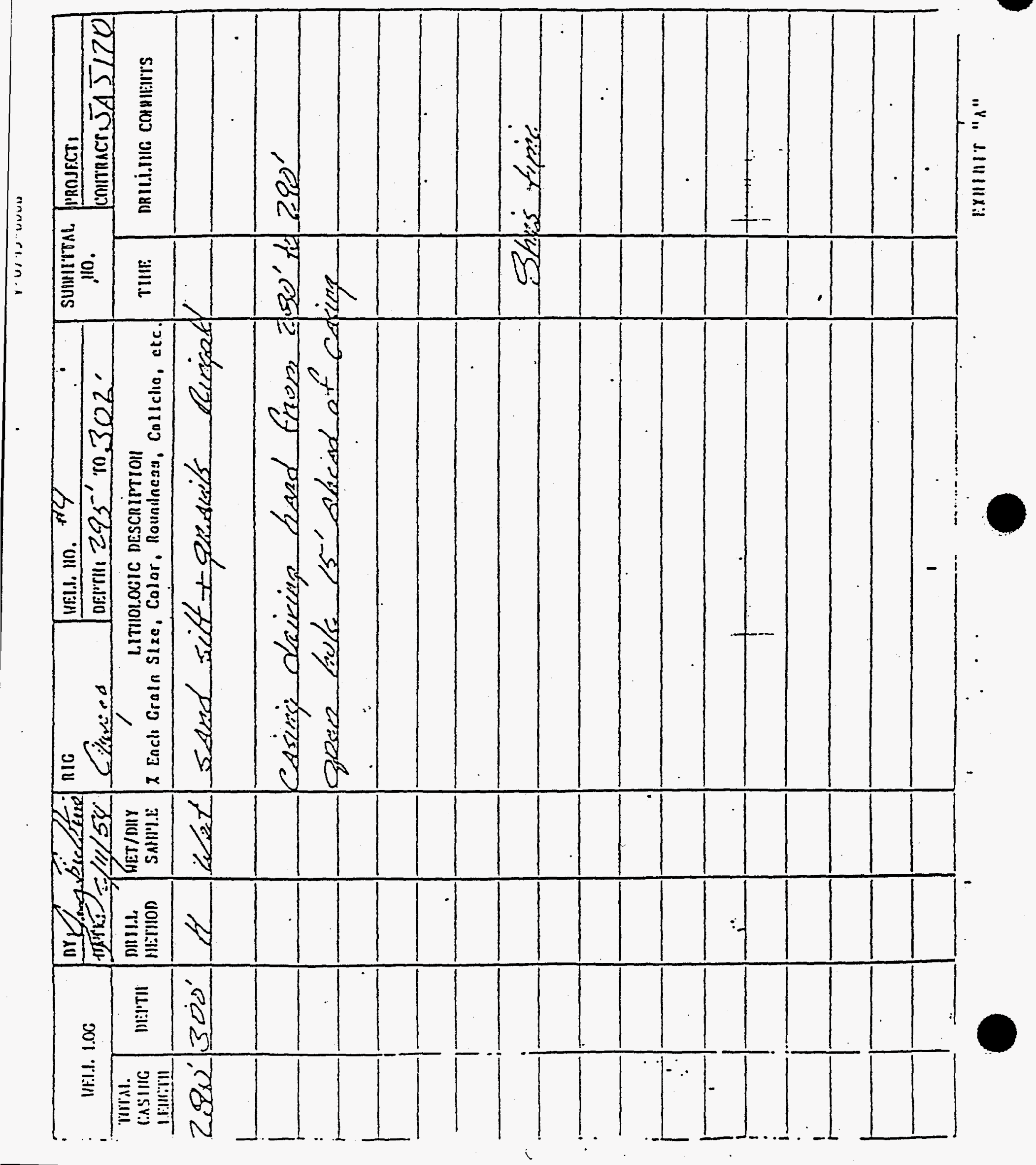


4CO Aisa Seconcary Cosiing Water

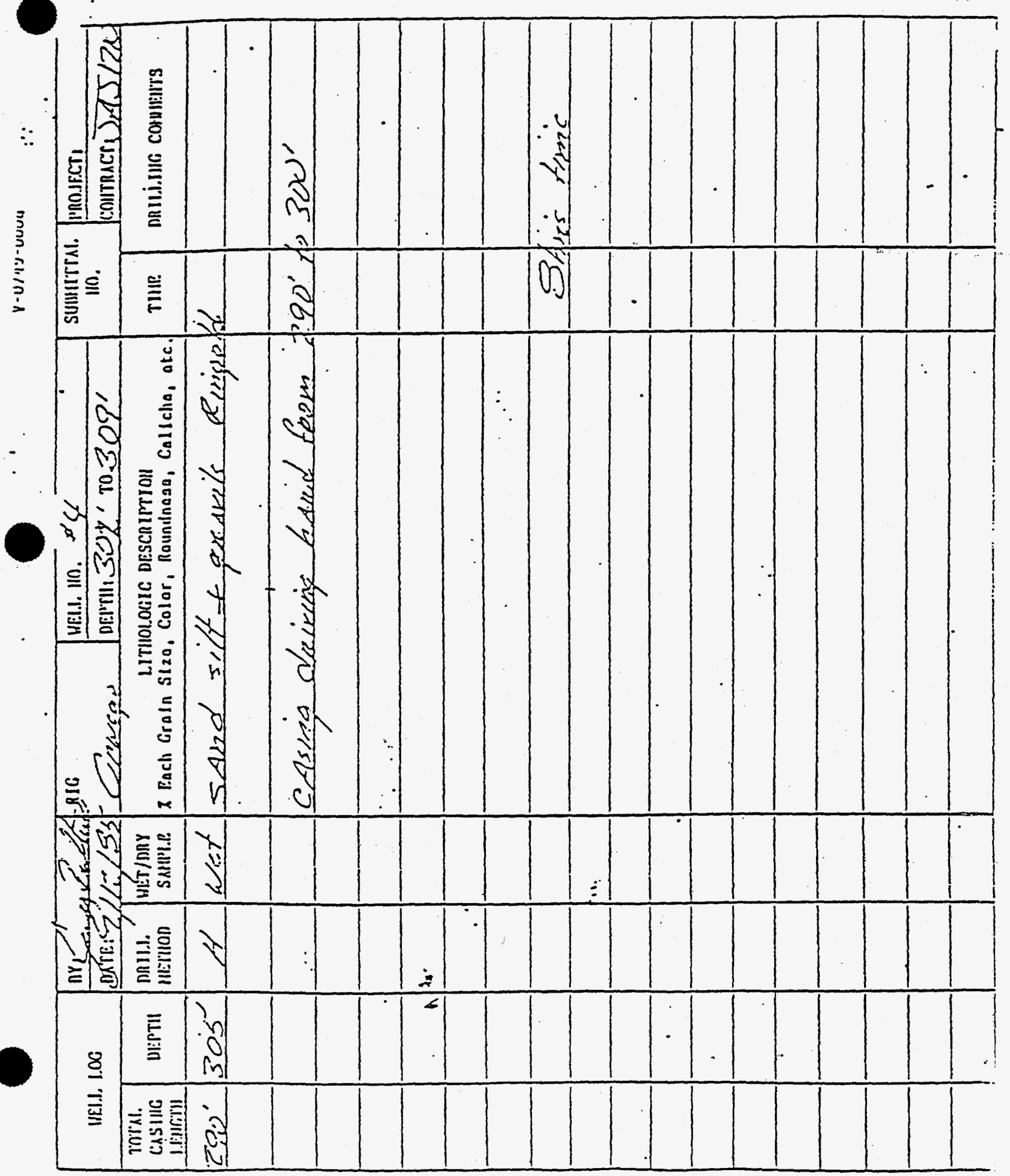




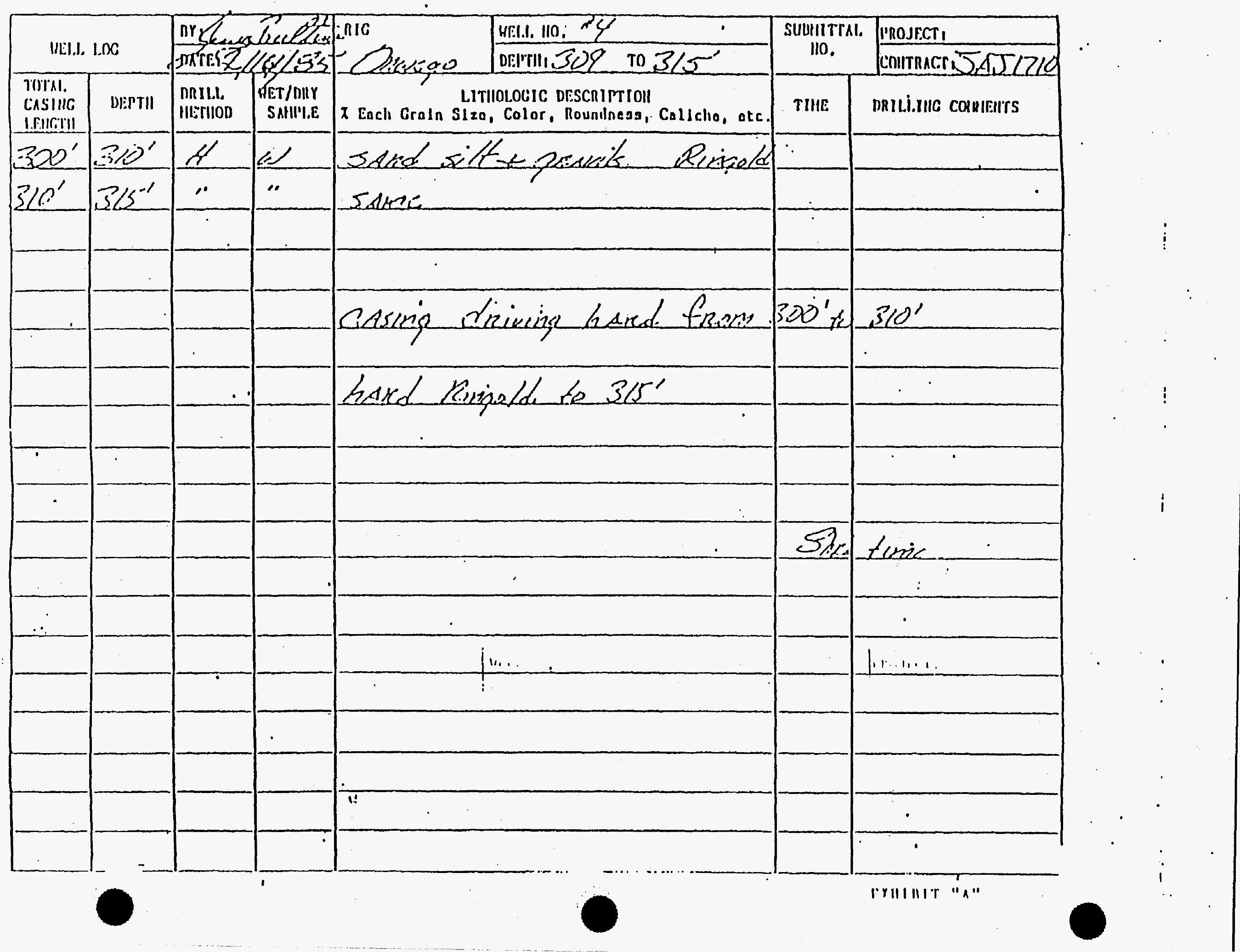




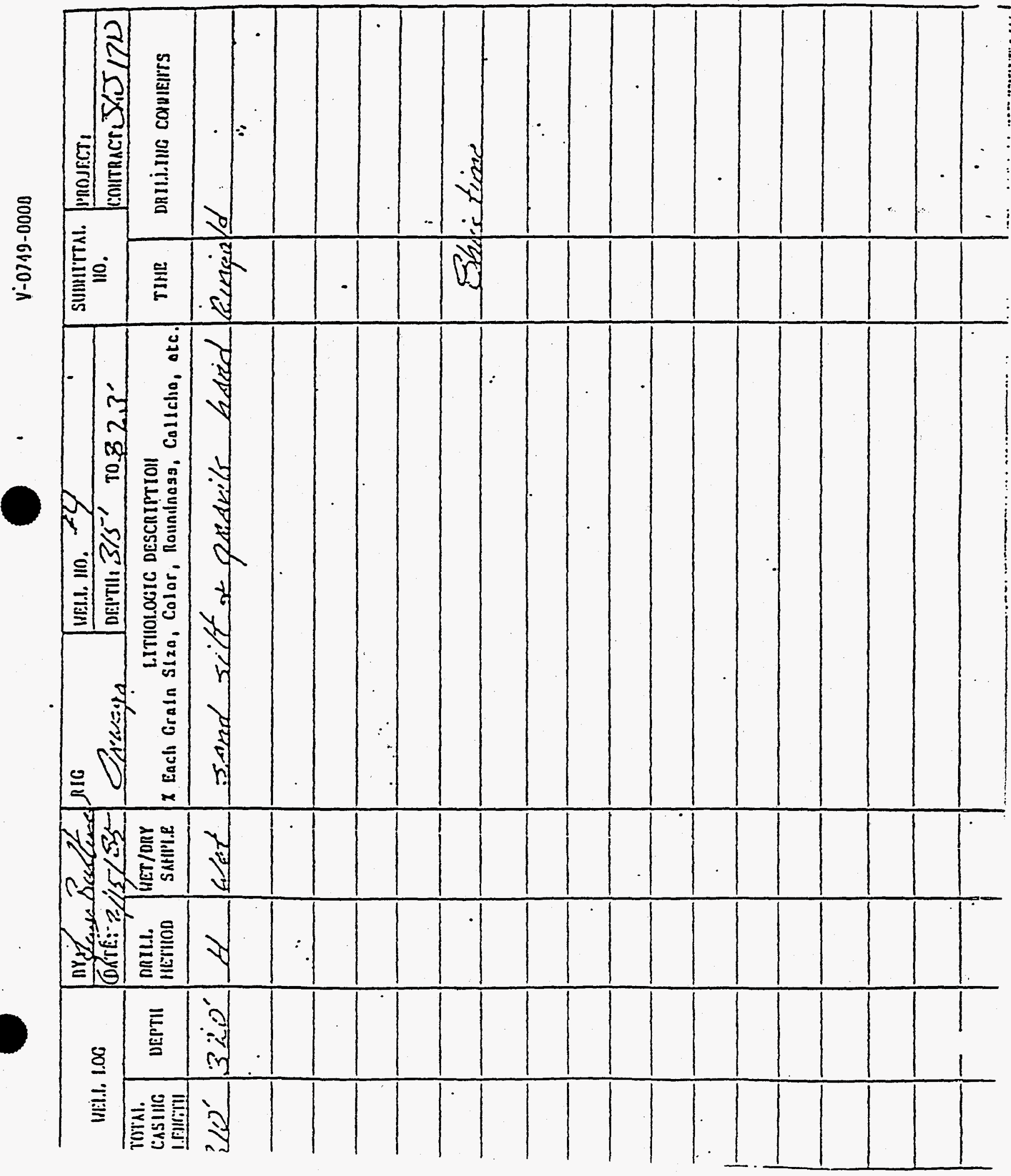




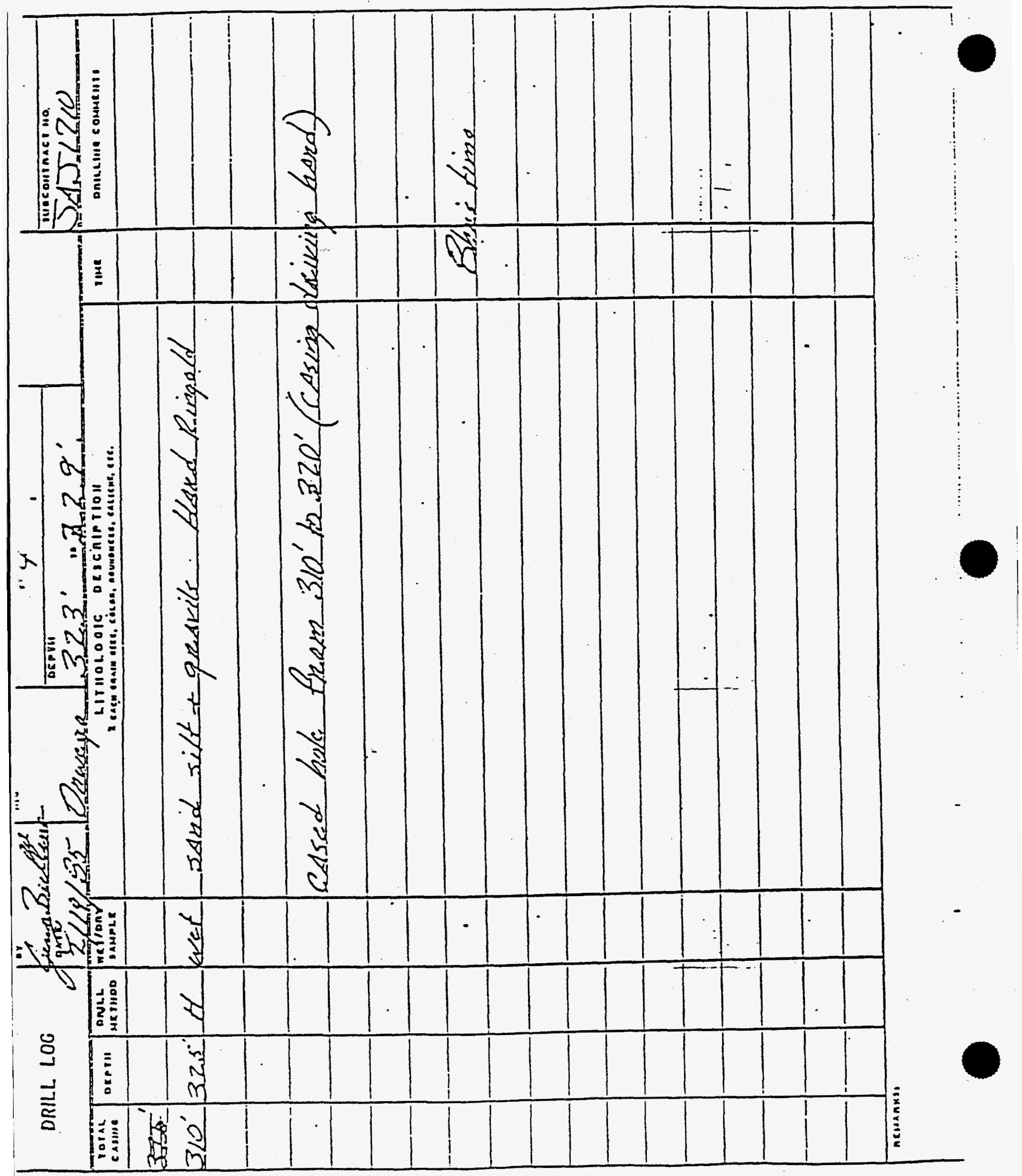


\$CO Area Seconciary Cooling Waler Altacinneme it
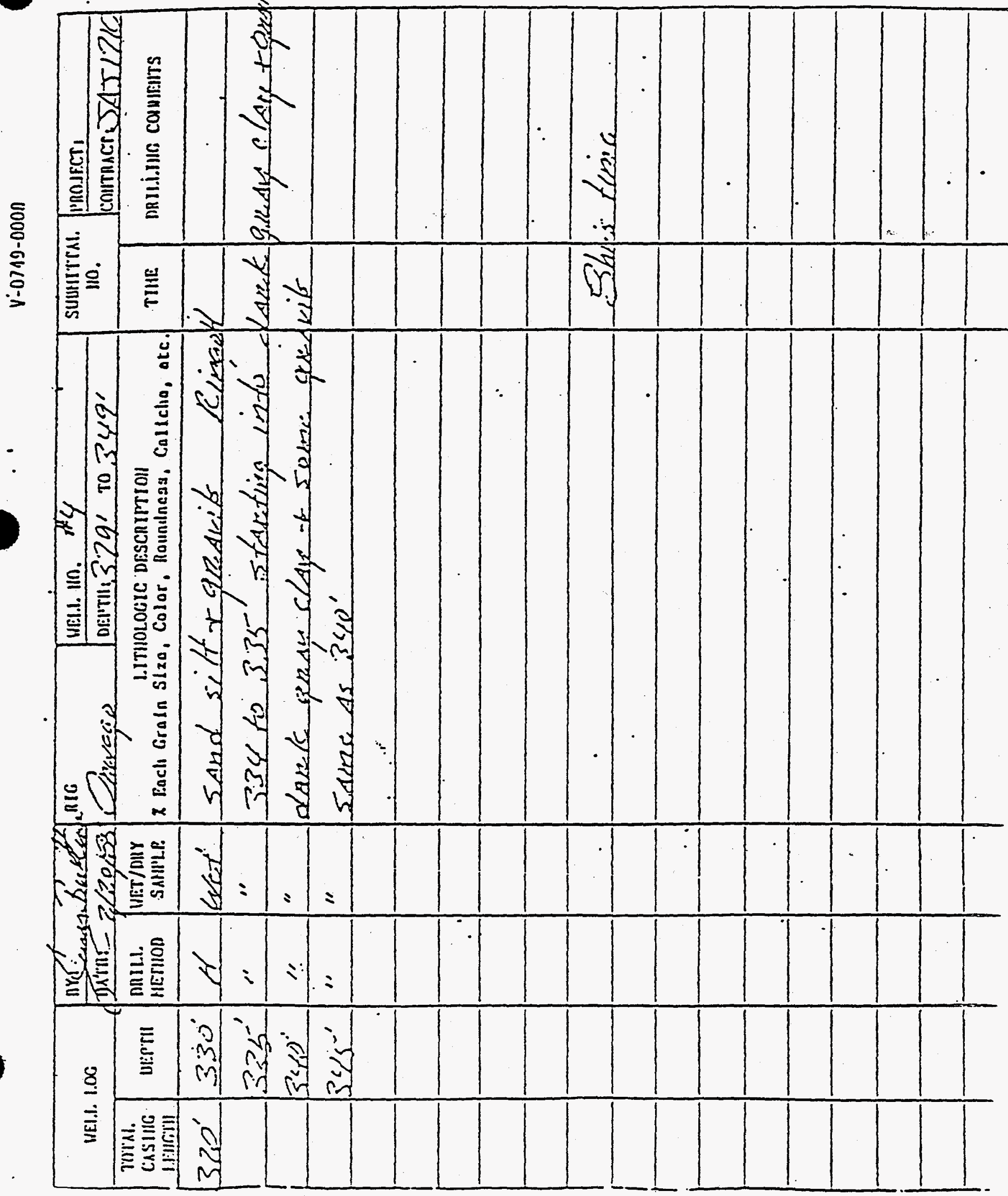


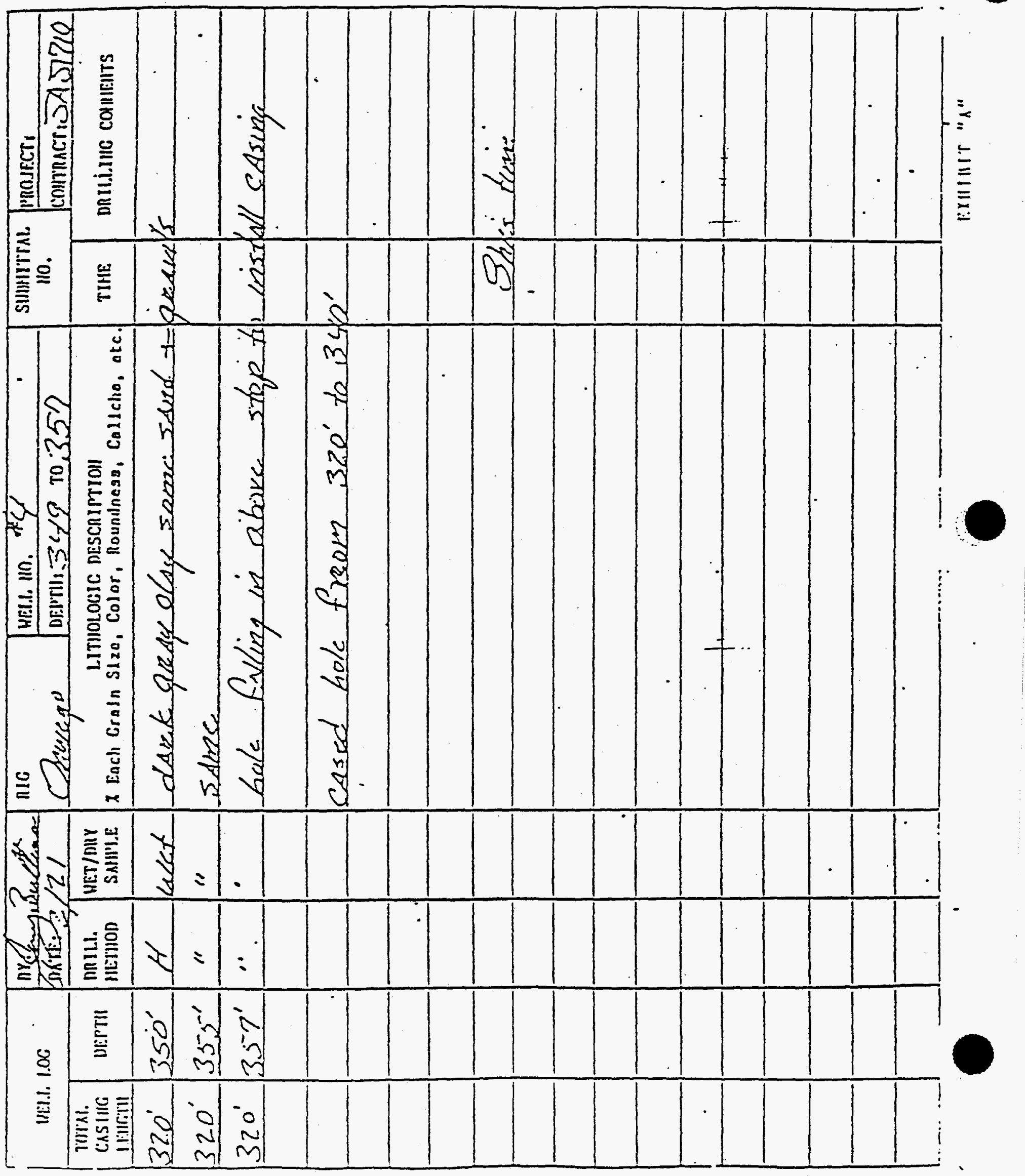




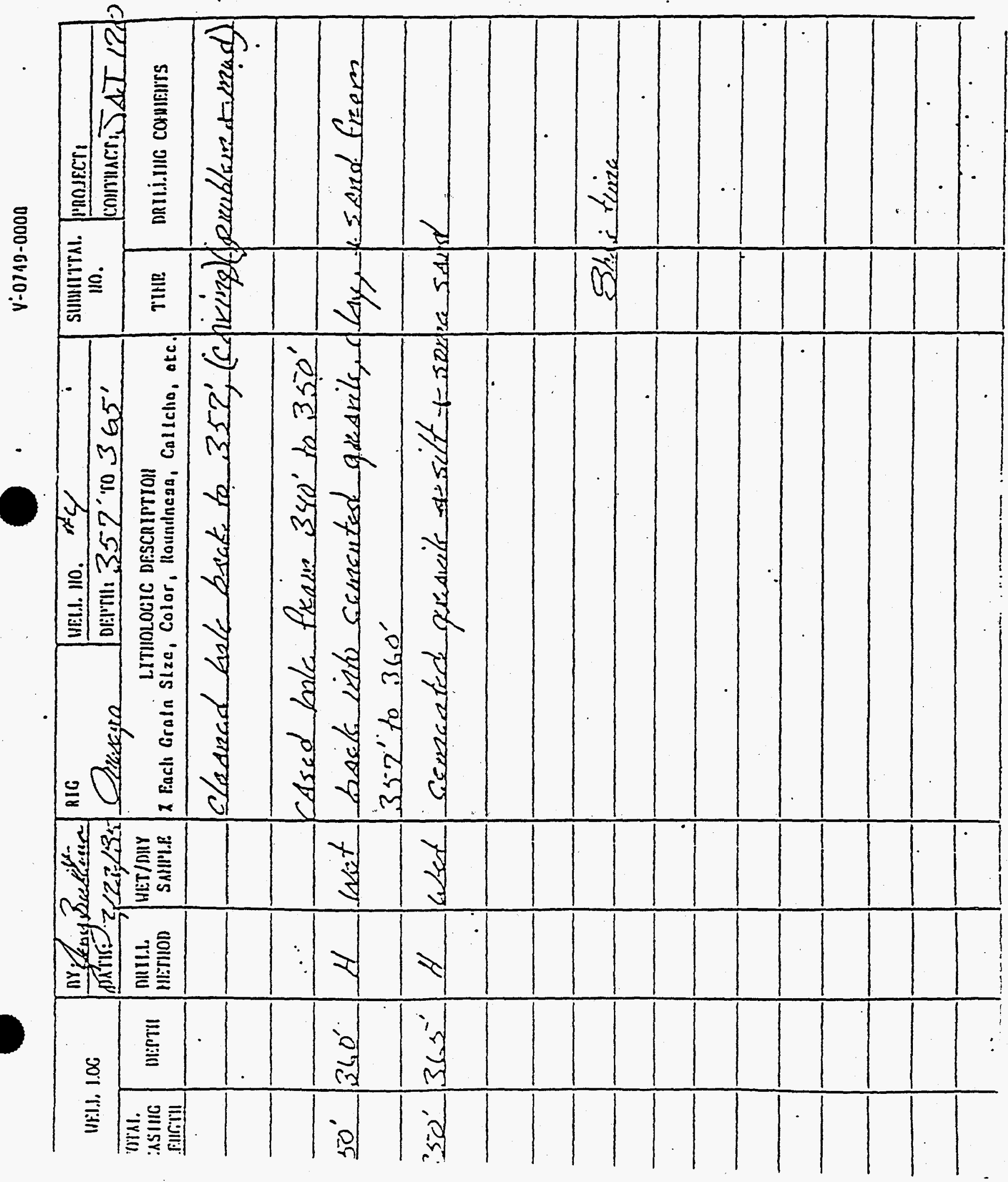




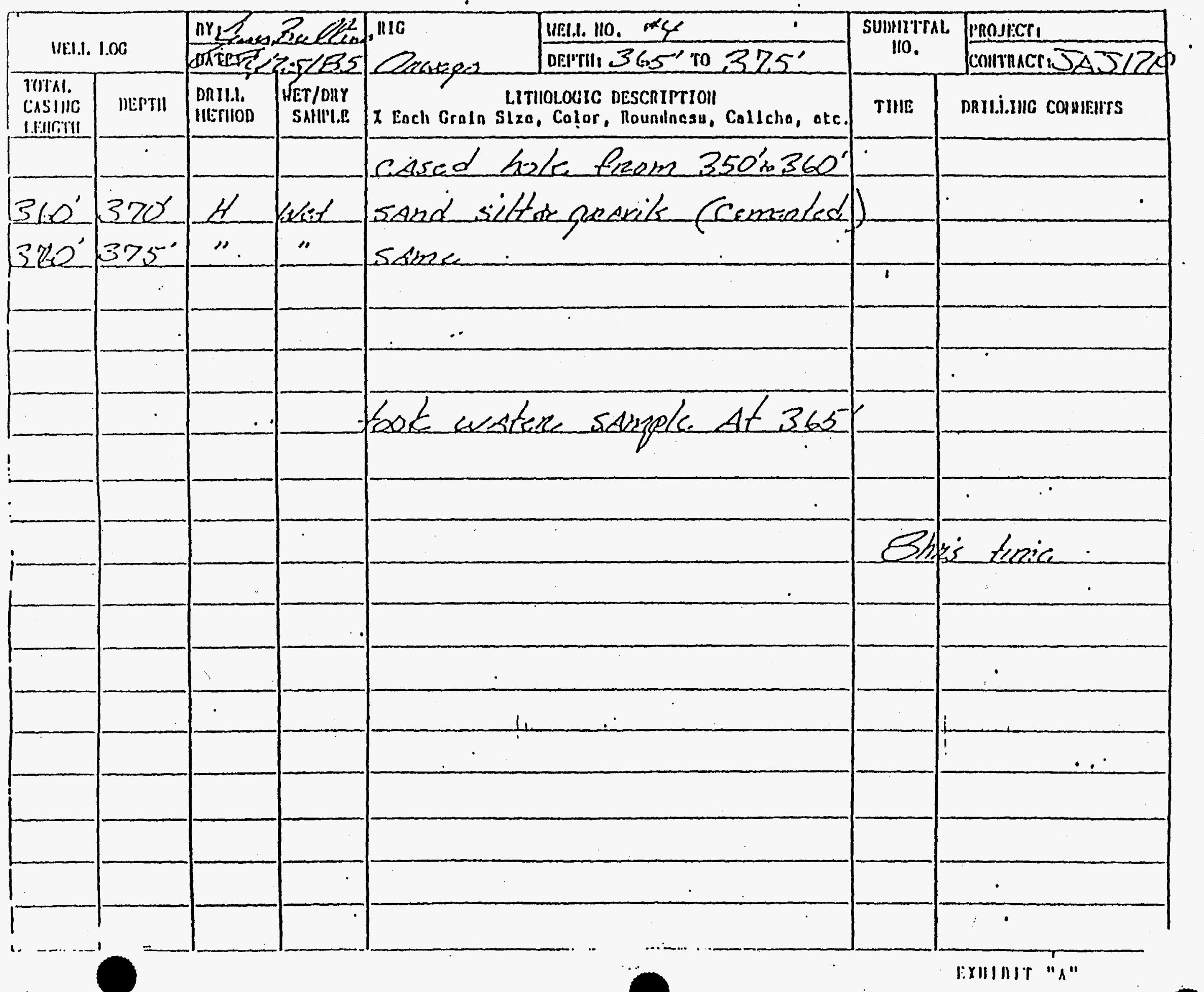




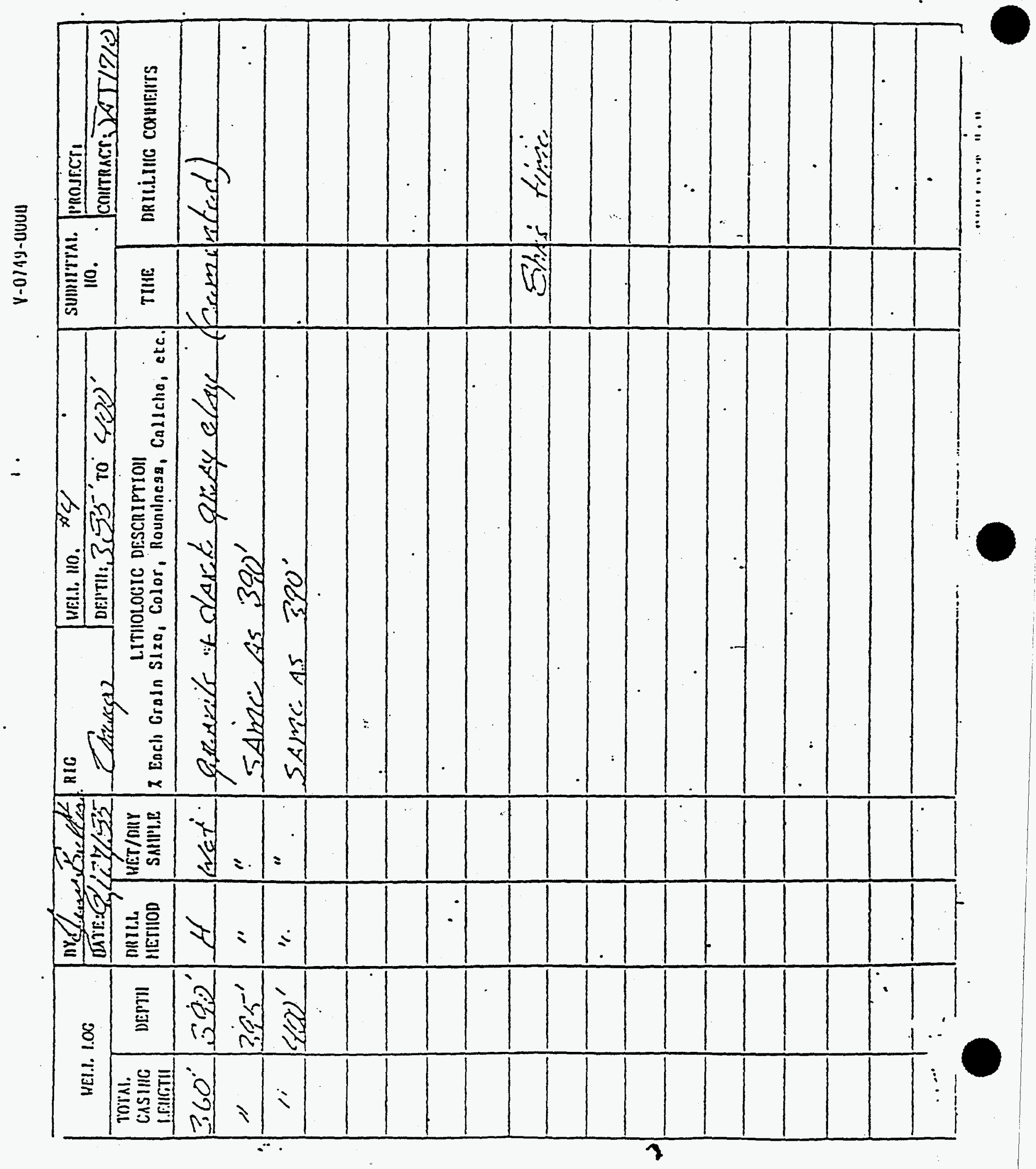




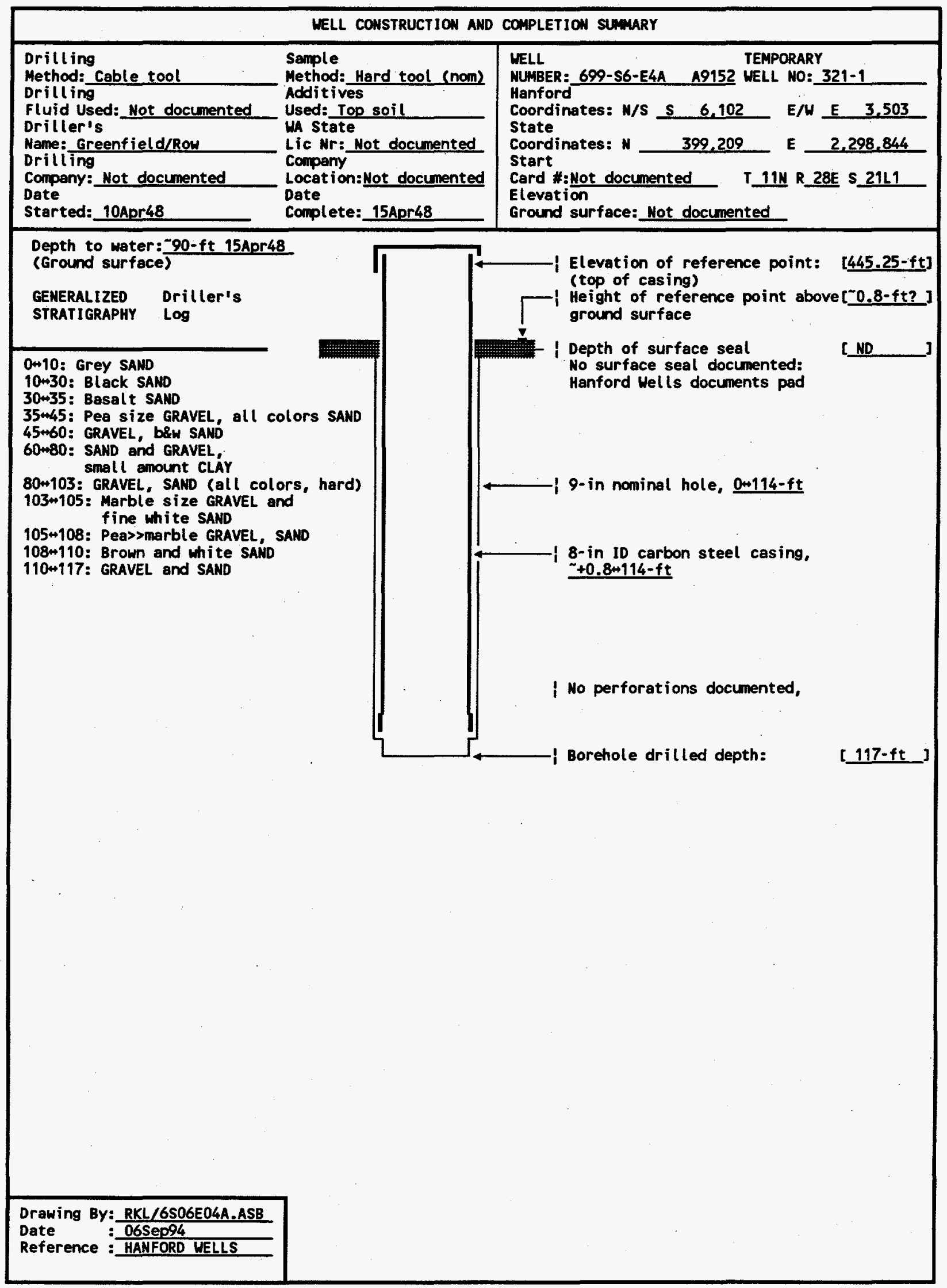




\section{SUMMARY OF CONSTRUCTION DATA AND FIELD OBSERVATIONS}

RESOURCE PROTECTION WELL - 699-S6-E4A

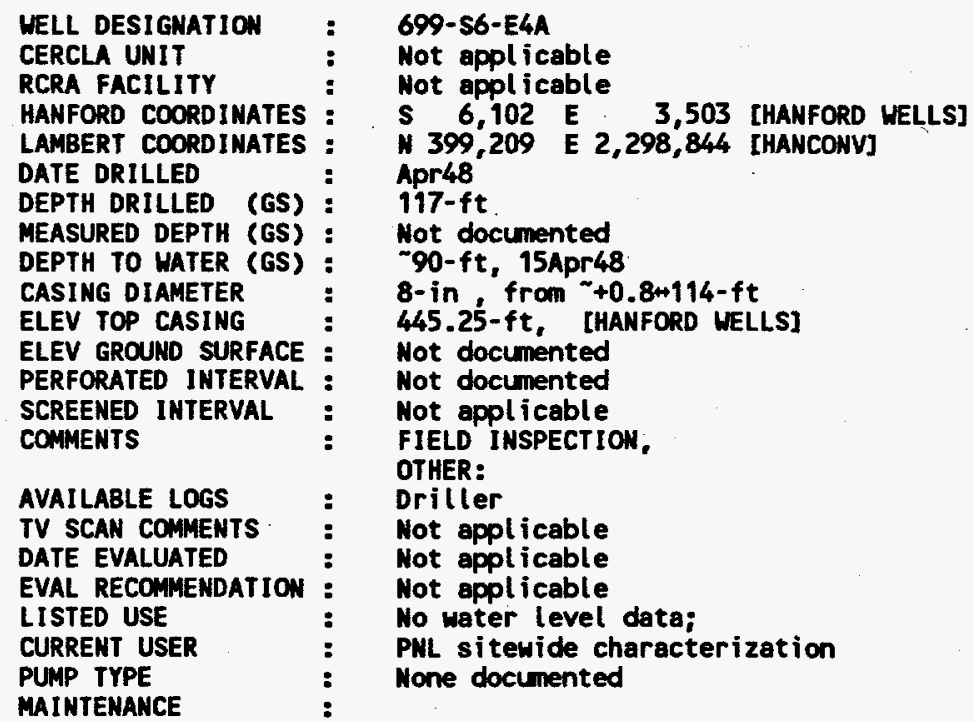




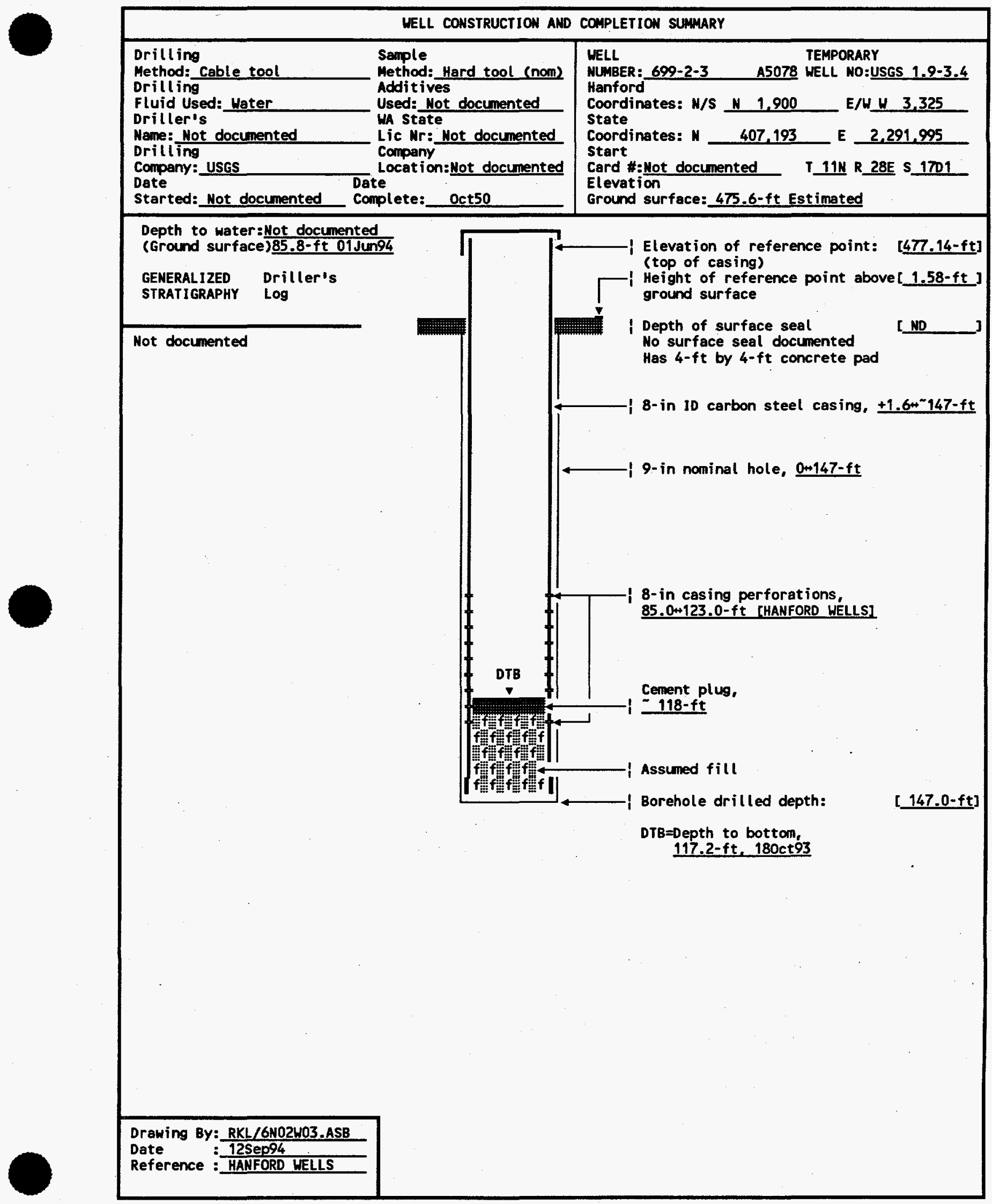




\section{SUMMARY OF CONSTRUCTION DATA AND FIELD OBSERVATIONS RESOURCE PROTECTION WELL - 699-2-3}

WELL DESIGNATION
RCRA FACILITY
CERCLA UNIT
HANFORD COORDINATES :
LAMBERT COORDINATES :
DATE DRILLED
DEPTH DRILLED (GS)
MEASURED DEPTH (GS)
DEPTH TO WATER (GS)
CASING DIAMETER
ELEV TOP OF CASING
ELEV GROUND SURFACE :
PERFORATED INTERVAL :
SCREENED INTERVAL :
COMMENTS

AVAILABLE LOGS

TV SCAN COMMENTS

DATE EVALUATED

EVAL RECOMMENDATION :

LISTED USE

CURRENT USER

PUNP TYPE

MAINTENANCE
699-2-3

Not applicable

Not applicable

N 1,900 H 3,325 [HANFORD MELLS]

N 407,193 E 2,291,995 [HANCONV]

Aug50

147.0-ft

$117.2-\mathrm{ft}, 180 \mathrm{ct} 93$

Not documented,

85.8-ft, 01 Jung 4

8-in, carbon steel, +1.6\$147.0-ft (nominal)

477.14-ft

475.6-ft.Estimated

85.0u123.0-ft [HANFORD WELLS]

Not appl icable

FIELD INSPECTION, 180ct93.

8-in carbon steel casing. Capped and locked

4-ft by 4-ft pad, no posts or permanent identification.

Not in radiation zone.

OTHER: Cement plug a 118-ft

Driller

Not applicable

Not appl icable

Not appl icable

Si tewide annual $w / l$ measurement, 01May91+01Jun94;

WHC ES\&M $w / L$ monitoring and sampling,

PNL sitewide sampling, w/l monitoring and sampling

Electric submersible

Maintenance activities documented in the Hanford Wells Database System 


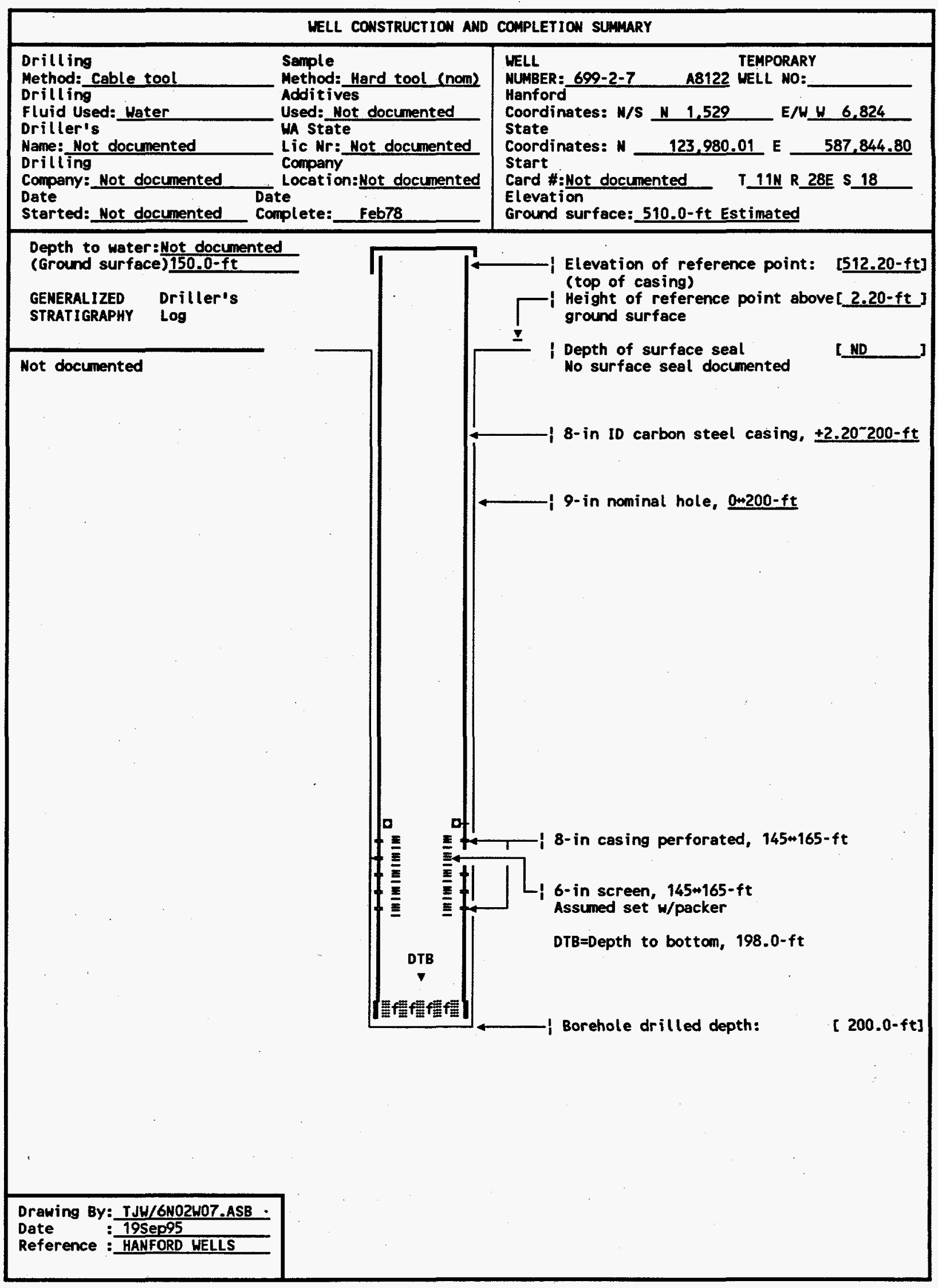




\section{SUMMARY OF CONSTRUCTION DATA AND FIELD OBSERVATIONS}

RESOURCE PROTECTION WELL - 699-2-7

MELL DESIGNATION
RCRA FACILITY
CERCLA UNIT
HANFORD COORDINATES
LAMBERT COORDINATES
DATE DRILLED
DEPTH DRILLED (GS)
MEASURED DEPTH (GS)
DEPTH TO WATER (GS)
CASING DIANETER
ELEV TOP OF CASING
ELEV GROUND SURFACE
PERFORATED INTERVAL
SCREENED INTERVAL
COMMENTS

AVAILABLE LOGS
TV SCAN COMMENTS
DATE EVALUATED
EVAL RECOMMENDATION
LISTED USE
CURRENT USER
PUMP TYPE
MAINTENANCE

MAINTENANCE

699-2-7 Not applicable Not applicable N 1,529 H

N $123,980.01 E$ 6,824 [HANFORD WELLS] Feb78 200.0-ft

198.0-ft, 20Sep95

Not documented,

150.0-ft 20sep95

8-in, carbon steel, $+2.2+200.0-\mathrm{ft}$ (nominal)

$512.20-\mathrm{ft}$

510.0-ft,Estimated

$145+165.00-\mathrm{ft}$ [HANFORD WELLS]

145-165.0-ft 6-in stainless screen

FIELD IUSPECTION, 20 Sep95.

8-in carbon steel casing. Capped and locked

no permenant identification, no posts or pad, Not in radiation zone.

OTHER:

Not documented

Not applicable

Not applicable

Not applicable

Sitewide annual $w / l$ measurement, 12Dec78 427 Jun95;

HHC ES\&H $\mathrm{w} / \mathrm{l}$ monitoring and sampling,

PNL sitewide sampling, w/l monitoring and sampling

Electric submersible

Maintenance activities documented in the Hanford Wells Database System 


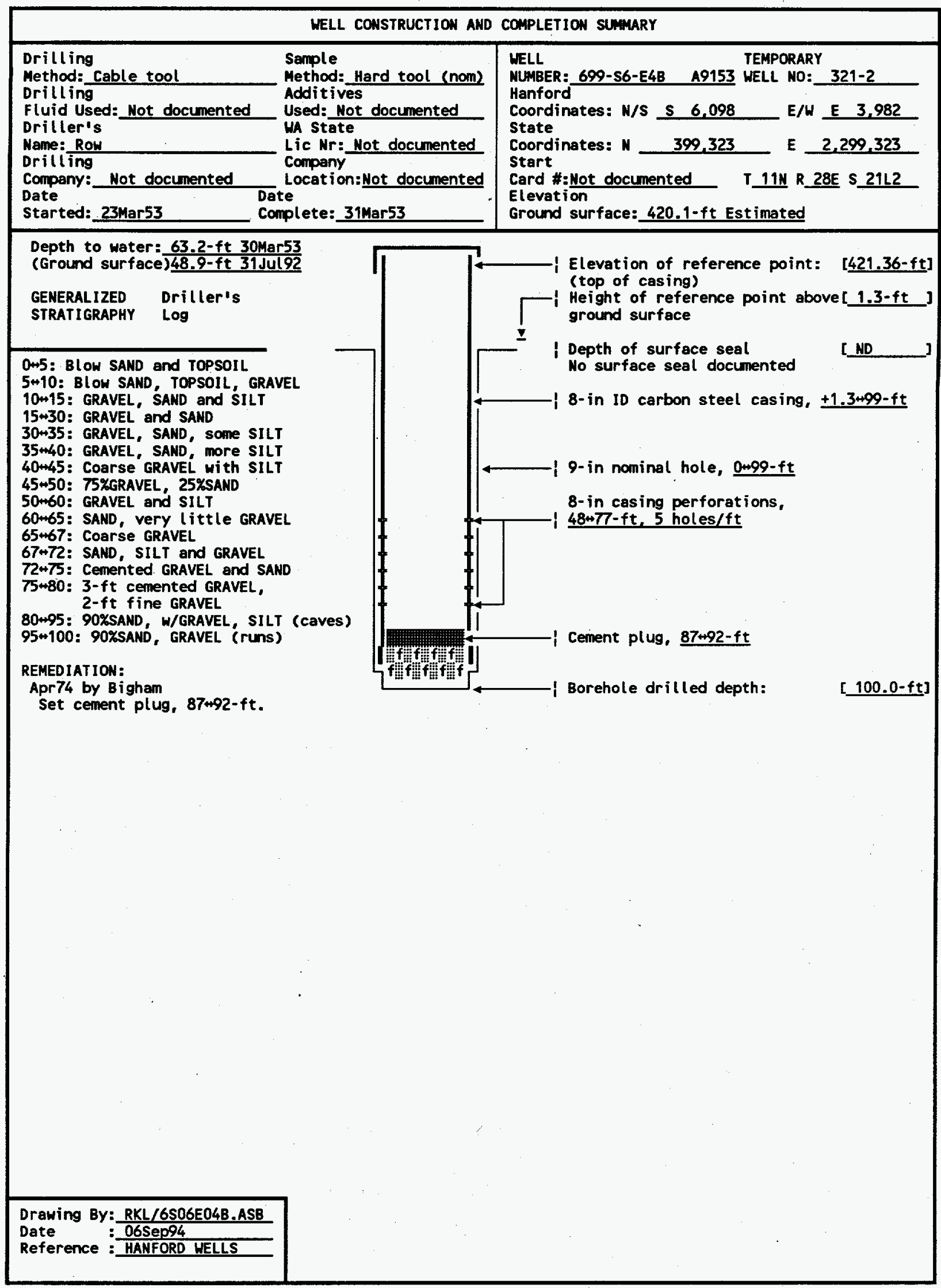




\section{SUMMARY OF CONSTRUCTION DATA AND FIELD OBSERVATIONS RESOURCE PROTECTION WELL - 699-S6-E4B}

WELL DESIGNATION
RCRA FACILITY
CERCLA UNIT
HANFORD COORDINATES :
LAMBERT COORDINATES :
DATE DRILLED
DEPTH DRILLED (GS)
MEASURED DEPTH (GS)
DEPTH TO WATER (GS)
CASING DIAMETER
ELEV TOP OF CASING
ELEV GROUND SURFACE :
PERFORATED INTERVAL :
SCREENED INTERVAL
COMMENTS
AVAILABLE LOGS
TV SCAN COMNENTS
DATE EVALUATED
EVAL RECOMMENDATION :
LISTED USE
CURRENT USER
PUMP TYPE
MAINTENANCE

699-56-E4B

Not applicable

Not applicable

S $6,098 \mathrm{E}$

Mar53

100-ft

Not documented

63.2-ft, 30Mar53

48.9-ft, $31 \mathrm{Jul}(92$

8-in, carbon steel, $+1.3+99-\mathrm{ft}$

421.36- $\mathrm{ft}$, [HANFORD WELLS]

420.1-ft, Estimated

$48 \omega 77-\mathrm{ft}$

Not appl icable

FIELD INSPECTION,

OTHER:

Driller

Not appl icable

Not appl icable

Not appl icable

Water levels measured, 20Feb90 31Jul92;

PNL sitewide sampling and characterization

Electric submersible

Maintenance activities documented in the Hanford Hells Database System 
WELL CONSTRUCTION AND COMPLETION SUMMARY

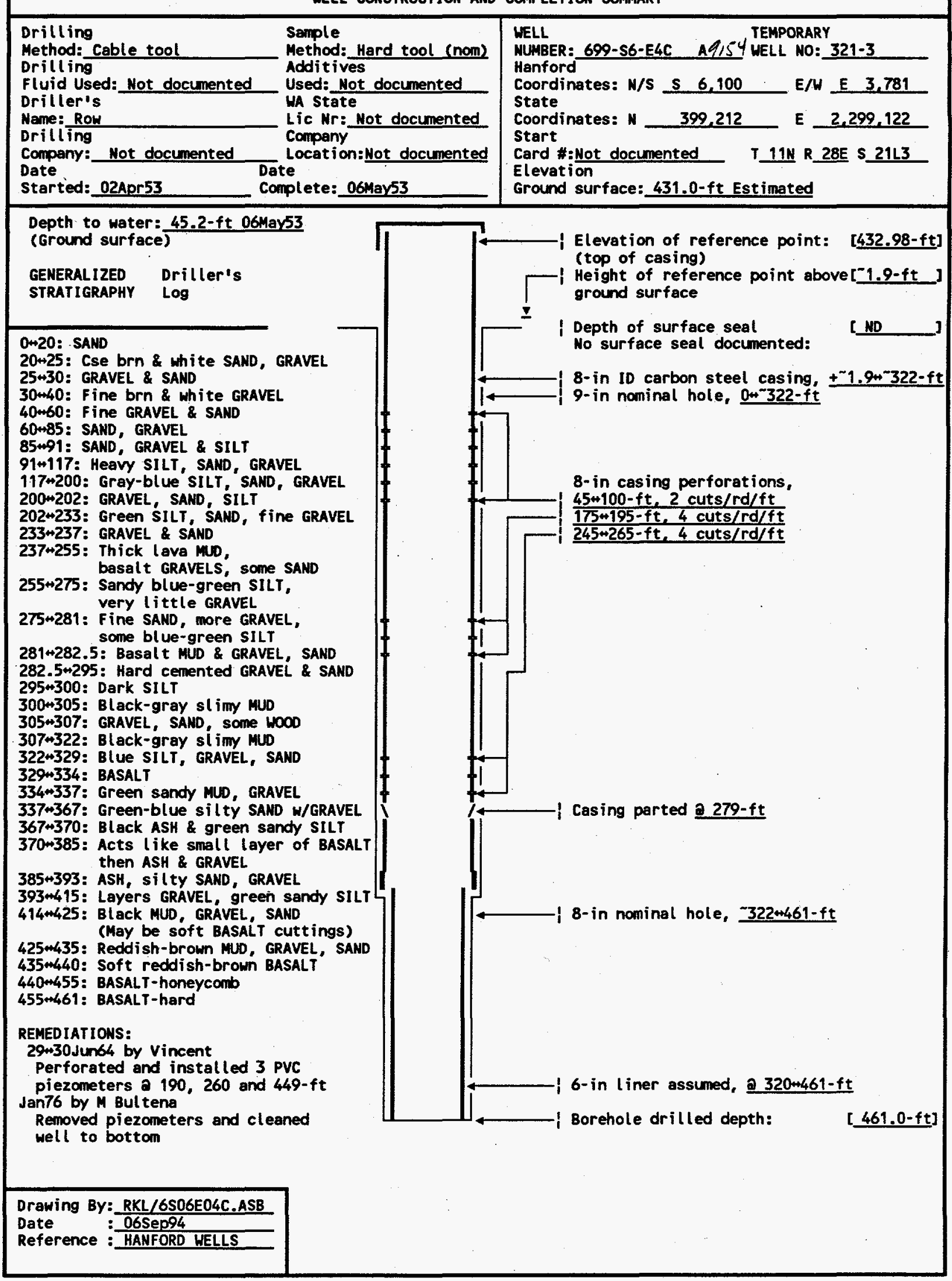




MELL DESIGNATION
RCRA FACILITY
CERCLA UNIT
HANFORD COORDINATES
LAMBERT COORDINATES :
DATE DRILLED
DEPTH DRILLED (GS)
MEASURED DEPTH (GS)
DEPTH TO WATER (GS)
CASING DIAMETER
ELEV TOP OF CASING
ELEV GROUND SURFACE :
PERFORATED INTERVAL :
SCREENED INTERVAL
COMMENTS
AVAILABLE LOGS
TV SCAN COMNENTS
DATE EVALUATED
EVAL RECOMHENDATION
LISTED USE
CURRENT USER
PUHP TYPE
MAINTENANCE
REMEDIATIONS

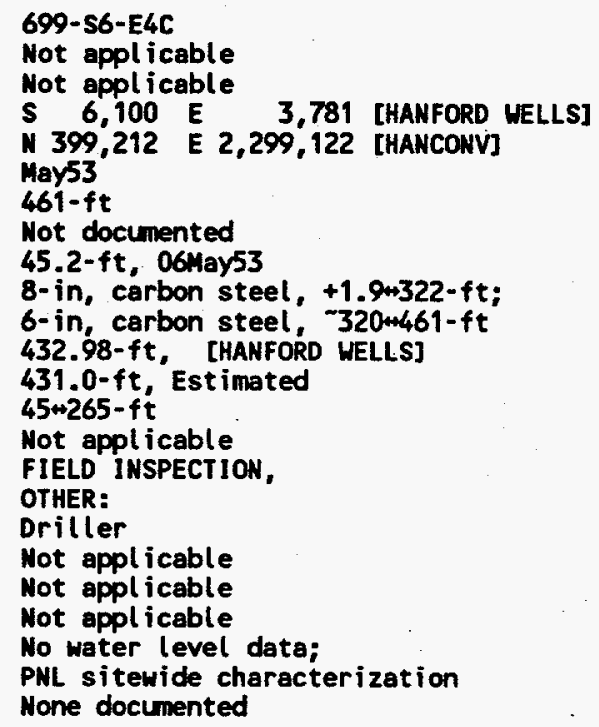




\section{MELL CONSTRUCTION AND COMPLETION SUMMARY}

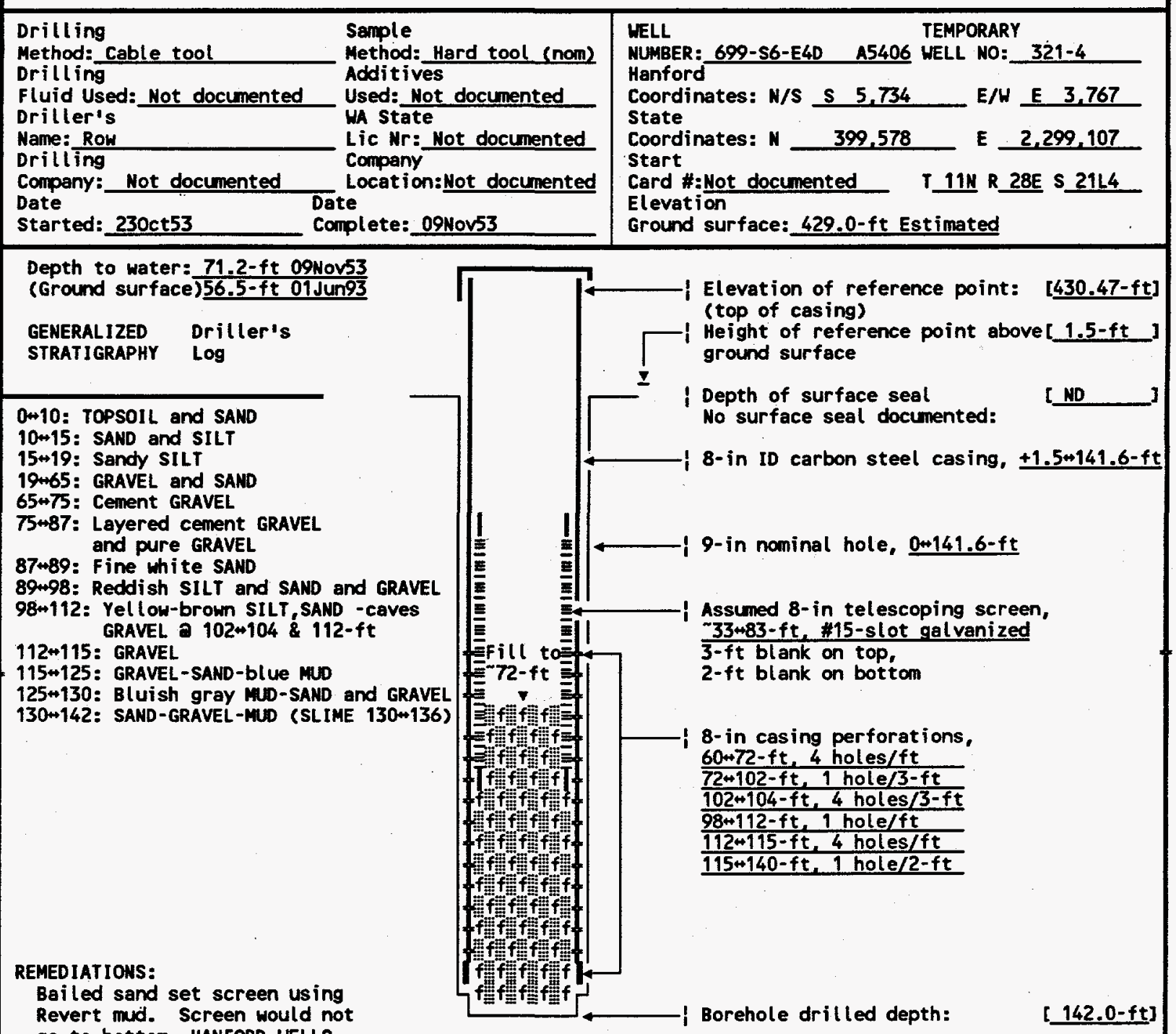

documents as 33+83-ft. 


\section{SUMMARY OF CONSTRUCTION DATA AND FIELD OBSERVATIONS \\ RESOURCE PROTECTION WELL - 699-S6-E4D}

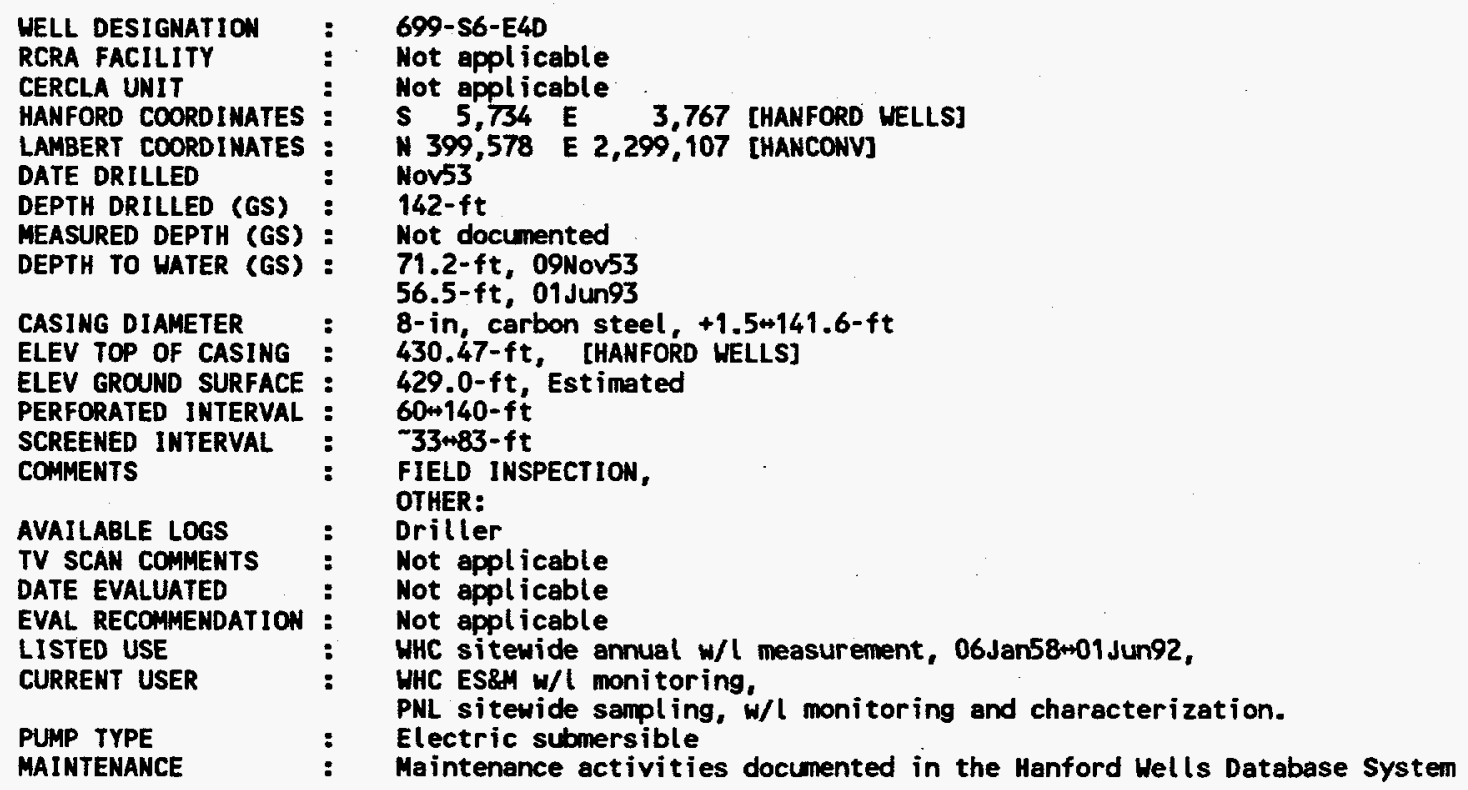


WELL CONSTRUCTION AND COMPLETION SUMMARY

$\begin{array}{ll}\text { Drilling } & \text { Sample } \\ \text { Method:_Cable tool } & \text { Method: Hard tool (nom) } \\ \text { Drilling } & \text { Additives } \\ \text { Fluid Used: Water } & \text { Used: Not documented } \\ \text { Driller's } & \text { WA State } \\ \text { Name: Row } & \text { Lic Nr: Not documented } \\ \text { Drilling } & \text { Company } \\ \text { Company:_Not documented } & \text { Location:Not documented } \\ \text { Date } & \text { Date } \\ \text { Started: 12Nov53 } & \text { Complete: 30Nov53 }\end{array}$

WELL

TEMPORARY

NUMBER: 699-S6-E4E A9155 WELL NO: 321-5

Hanford

Coordinates: N/S S 6.446 E/H E 3.727

State

Coordinates: N $398,866 \quad$ E 2,299,068

Start

Card \#: Not documented T 11N R 28E S $21 \mathrm{L5}$

Elevation

Ground surface: $424.2-f t$ Estimated

Depth to water: $67.0-\mathrm{ft} 30$ Hov 53

(Ground surface)

GENERALIZED Driller's

STRATIGRAPHY LOg

0 $\rightarrow 13$ : BL OW SAND - and TOPSOIL

13+65: GRAVEL, w/2 $+3-\mathrm{ft}$ layers SAND

50+60: Layers GRAVEL and SAND

60+72: Cement GRAVEL

72+76: SAND and GRAVEL

76m79: GRAVEL and SAND

79m80: White SAMD

80+86: Cement GRAVEL and SAND

86m1: SAND and GRAVEL, w/light brn SILT

91498: SAND and GRAVEL W/gray SILT

98+120: GRAVEL and SAND w/dark MUD

(Smel (s)

NOTE: Had 43-ft of sand in hole after perforating

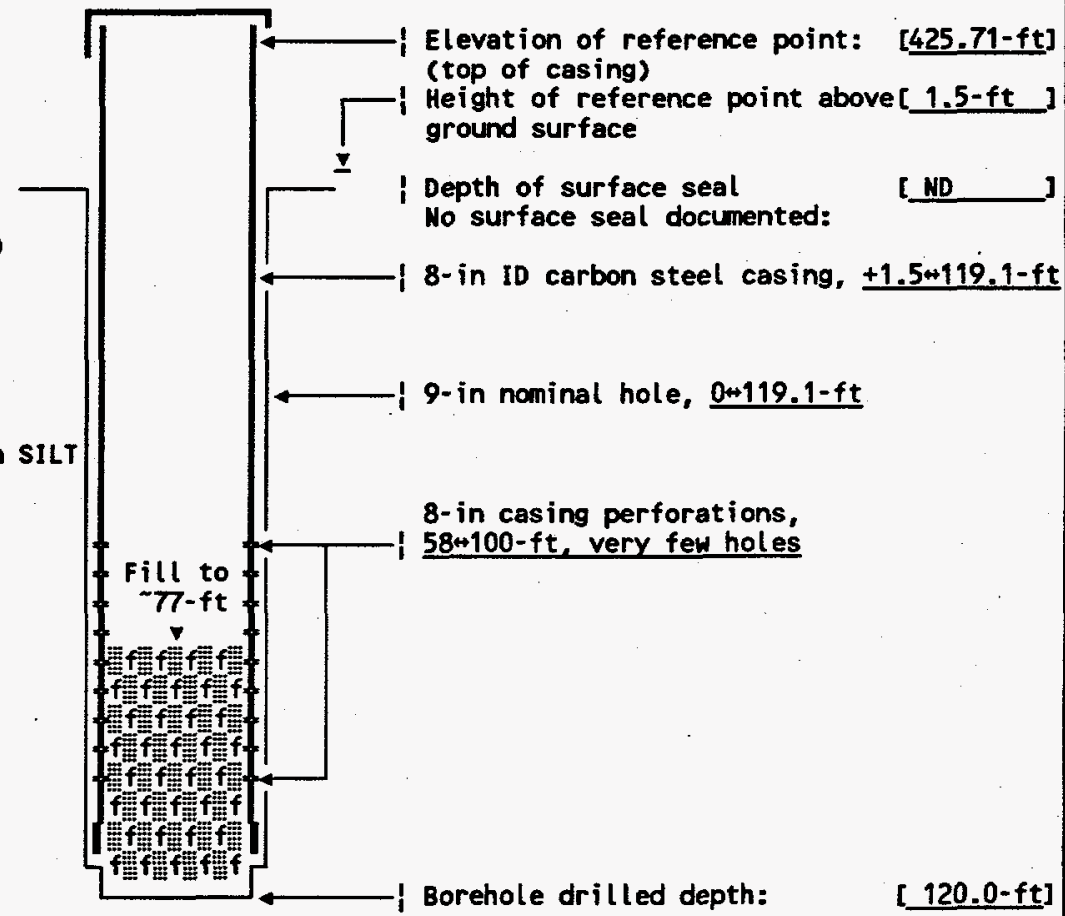

Drawing By: RKL/6S06E04E.ASB

Date $=06$ Sep94

Reference: HANFORD WELLS 


\title{
SUMMARY OF CONSTRUCTION DATA AND FIELD OBSERVATIONS RESOURCE PROTECTION WELL - 699-S6-E4E
}

\author{
WELL DESIGNATION : 699-S6-E4E \\ RCRA FACILITY : Not applicable \\ CERCLA UNIT : Not applicable \\ MANFORD COORDINATES : S 6,446 E 3,727 [HANFORD WELLS] \\ LAMBERT COORDINATES: $\quad$ 398,866 E 2,299,068 [HANCONV] \\ DATE DRILLED \\ DEPTH DRILLED (GS) : 120-ft \\ MEASURED DEPTH (GS) : Not documented \\ DEPTH TO WATER (GS) : $67.0-\mathrm{ft}, 30$ Nov 53 \\ CASING DIAMETER \\ ELEV TOP OF CASING \\ ELEV GROUND SURFACE : \\ PERFORATED INTERVAL : \\ SCREENED INTERVAL \\ COMMENTS \\ 8-in, carbon steel, $+1.5-119.1-\mathrm{ft}$ \\ 425.71-ft, [HANFORD WELLS] \\ 424.2-ft, Estimated \\ $58+100-f t$ \\ Not appl icable \\ FIELD INSPECTION, \\ OTHER: \\ AVAILABLE logs : Driller \\ TV SCAN COMMENTS : Not applicable \\ DATE EVALUATED : Not applicable \\ EVAL RECOMMENDATION : Not appl icable \\ LISTED USE \\ CURRENT USER \\ PUMP TYPE \\ No water level data \\ PNL sitewide characterization \\ MAINTENANCE \\ None documented \\ REMEDIATIONS
}


WELL CONSTRUCTION AND COMPLETION SUMMARY

\begin{tabular}{ll}
\hline Drilling & Sample \\
Method:_Cable tool & Method: Hard tool (nom) \\
Drilling & Additives \\
Fluid Used: Not documented & Used: Not documented \\
Driller's & WA State \\
Name: Row \& Jack & Lic Nr: Not documented \\
Drilling & Company \\
Company: Not documented & Location: Not documented \\
Date & Date \\
Started:21Dec53 & Complete: 04Jan54
\end{tabular}

WELL

TEMPORARY

MUMBER: 699-S6-E4F A9156 WELL MO:

Hanford

Coordinates: $\mathrm{N} / \mathrm{S}$ S 6,595

E/W E 3,950

State

Coordinates: N 1398,717 E $2,299,292$

Start

Card \#: Not documented T 11N R 28E S $21 L 6$

Elevation

Ground surface: $417.2-\mathrm{ft}$ Estimated

Depth to water: $61.4-\mathrm{ft} 04 \mathrm{Jan} 54$

(Ground surface)

GENERALIZED

STRATIGRAPHY

Driller's

$\log$

$0+10$ : Top SOIL and SAND

10 +18 : BOULDERS up to 10-in diameter

18 $\$ 55$ : GRAVEL, SAND

55.465: Cement GRAVEL \& SAND

65+67: Fine SAND-some SILT, white

67+90: White SAND, GRAVEL, mixed

w/fine SILT, white>stan

90+102: GRAVEL, SAND, tan SILT, muddy

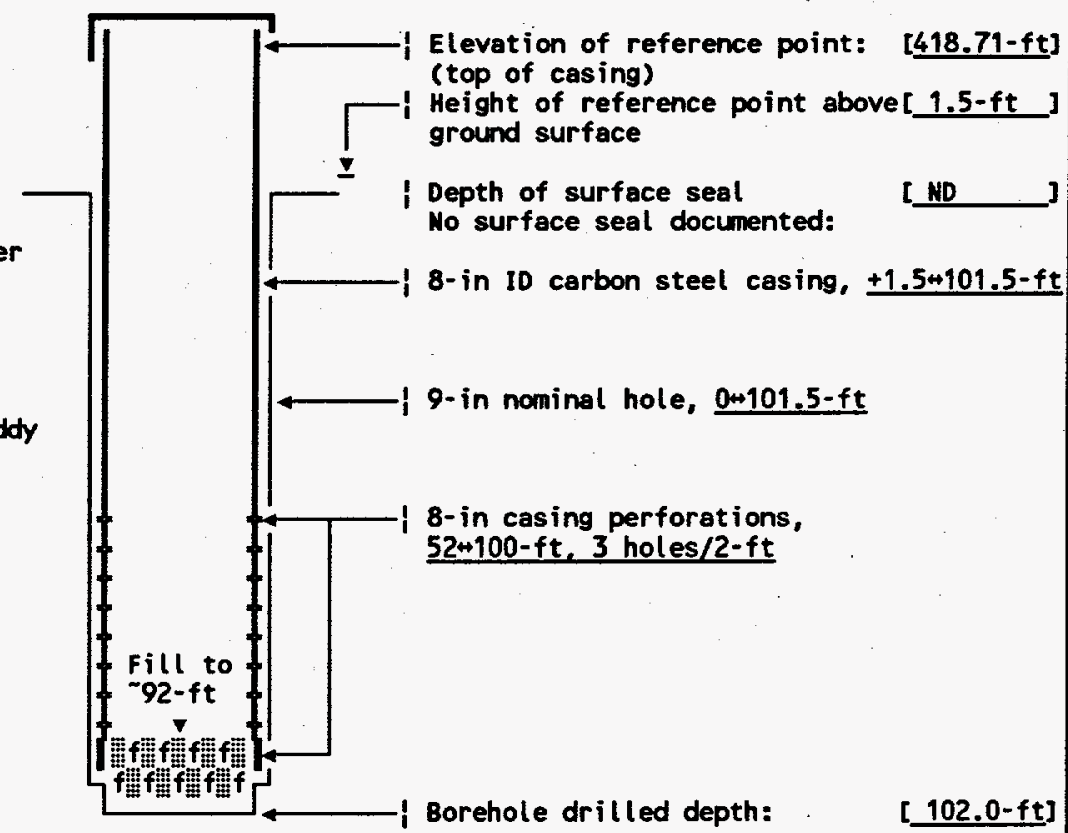

Drawing BY: RKL/6S06E04F.ASB

Date : 06 Sep94

Reference : HANFORD WELLS 


\section{SUMMARY OF CONSTRUCTION DATA AND FIELD OBSERVATIONS \\ RESOURCE PROTECTION WELL - 699-S6-E4F}

WELL DESIGNATION
RCRA FACILITY
CERCLA UNIT
HANFORD COORDINATES
LAMBERT COORDINATES
DATE DRILLED
DEPTH DRILLED (GS)
MEASURED DEPTH (GS)
DEPTH TO WATER (GS)
CASING DIAMETER
ELEV TOP OF CASING
ELEV GROUND SURFACE
PERFORATED INTERVAL
SCREENED INTERVAL
COMMENTS
AVAILABLE LOGS
TV SCAN COMHENTS
DATE EVALUATED
EVAL RECOMMENDATION
LISTED USE
CURRENT USER
PUMP TYPE
MAINTENANCE

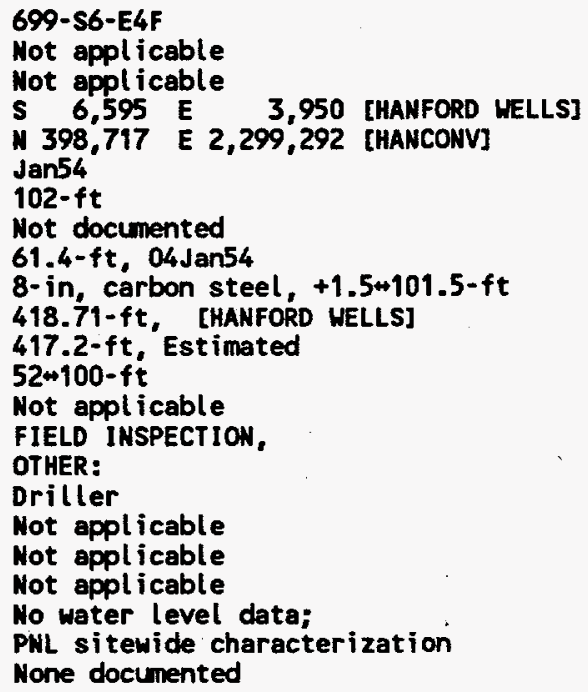




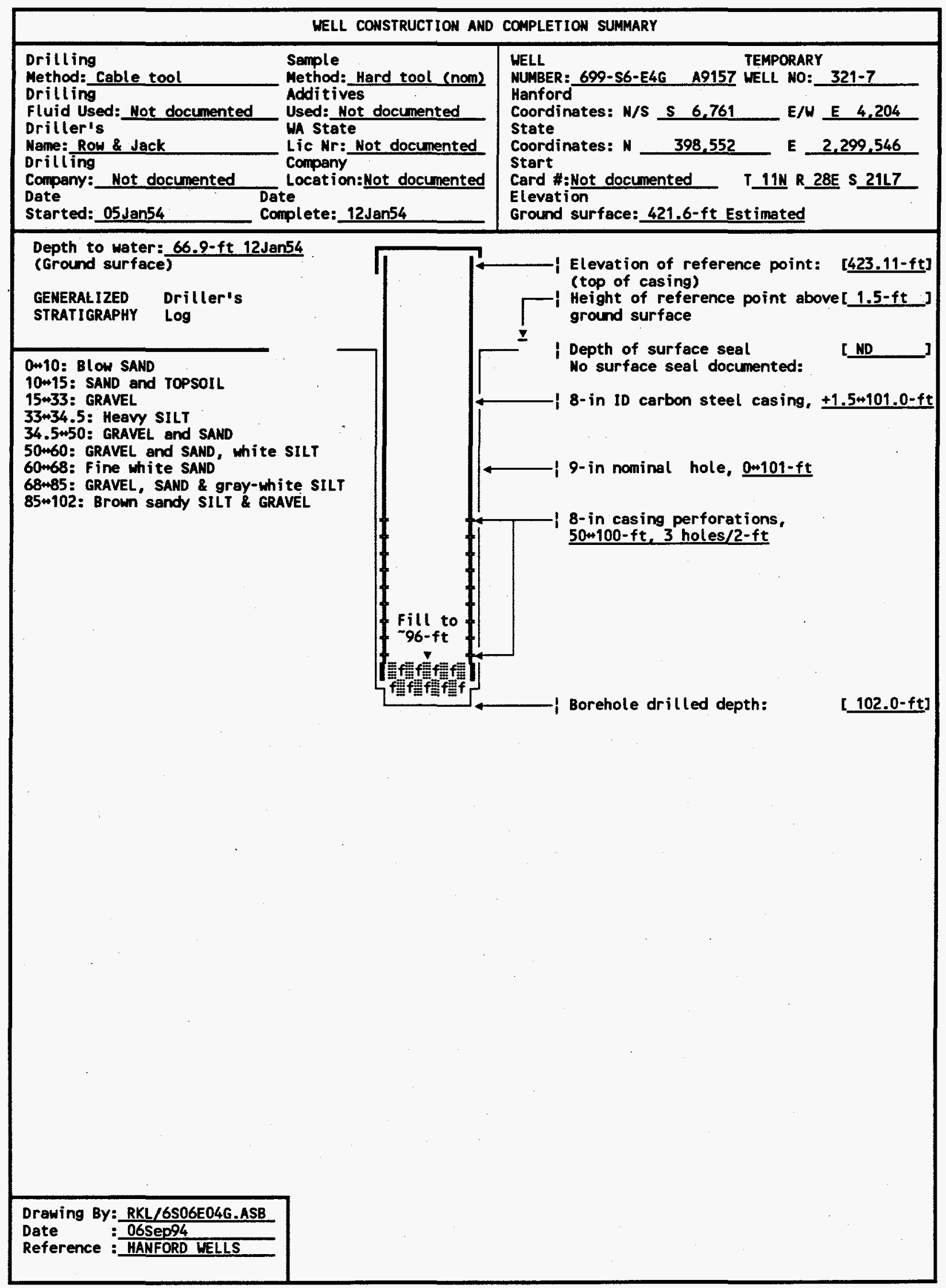




\title{
SUMMARY OF CONSTRUCTION DATA AND FIELD OBSERVATIONS RESOURCE PROTECTION WELL - 699-S6-E4G
}

\author{
NELL DESIGNATION : 699-S6-E4G \\ RCRA FACILITY . : Not applicable \\ CERCLA UNIT : Not applicable \\ HANFORD COORDINATES: $S 6,761$ E 4,204 [HANFORD WELLS] \\ LAMBERT COORDINATES : N 398,552 E 2,299,546 [HANCONV] \\ DATE DRILLED \\ MEASURED DEPTH (GS) : Hot documented \\ DEPTH TO WATER (GS) : $66.9-\mathrm{ft}, 12 \mathrm{Jan} 54$ \\ CASING DIAMETER \\ ELEV TOP OF CASING \\ ELEV GROUND SURFACE : \\ PERFORATED INTERVAL \\ SCREENED INTERVAL \\ COMMENTS \\ 8 -in, carbon steel, $+1.5+101.0-\mathrm{ft}$ \\ $423.11-\mathrm{ft}$, [HANFORD WELLS] \\ 421.6-ft, Estimated \\ 50w100-ft \\ Not applicable \\ FIELD INSPECTION, \\ TV SCAN COMMENTS : Not appl icable \\ DATE EVALUATED \\ Not appl icable \\ Not applicable \\ No water level data; \\ LISTED USE \\ CURRENT USER \\ PNL sitewide characterization \\ None documented \\ PUMP TYPE \\ MAINTENANCE
}




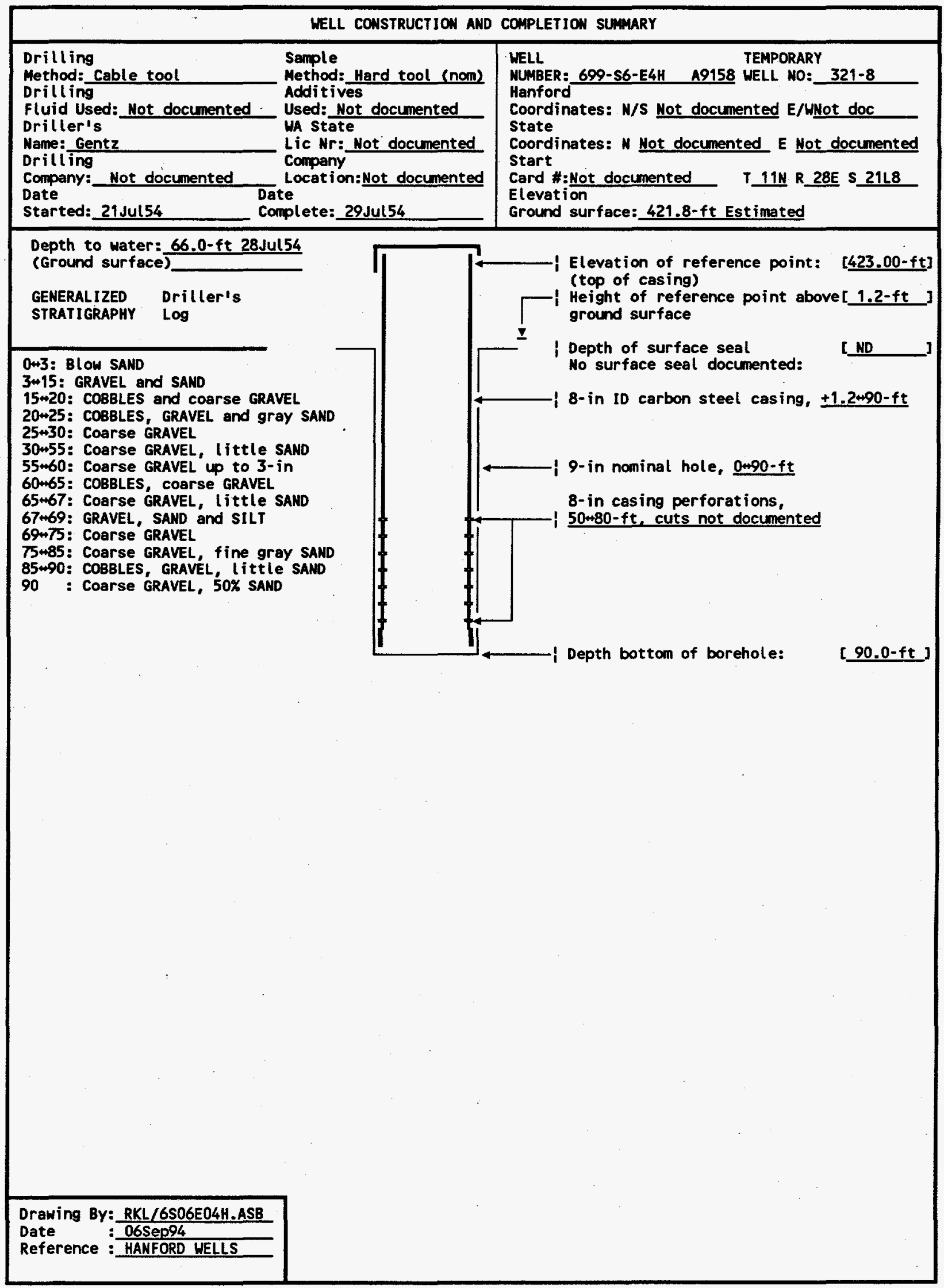




\section{SUMMARY OF CONSTRUCTION DATA AND FIELD OBSERVATIONS \\ RESOURCE PROTECTION WELL - 699-S6-E4H}

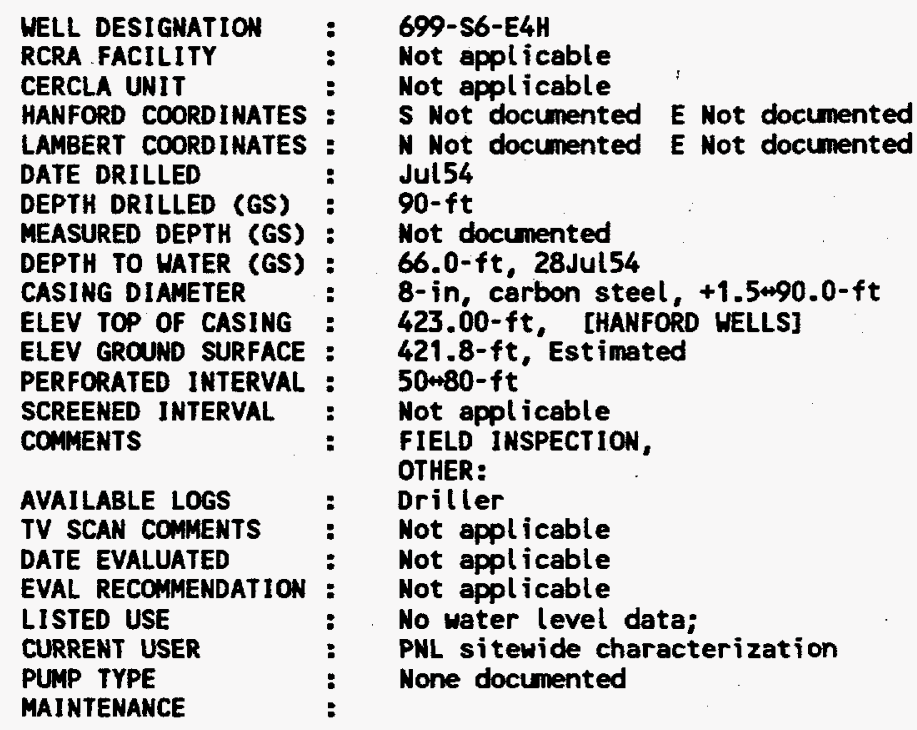




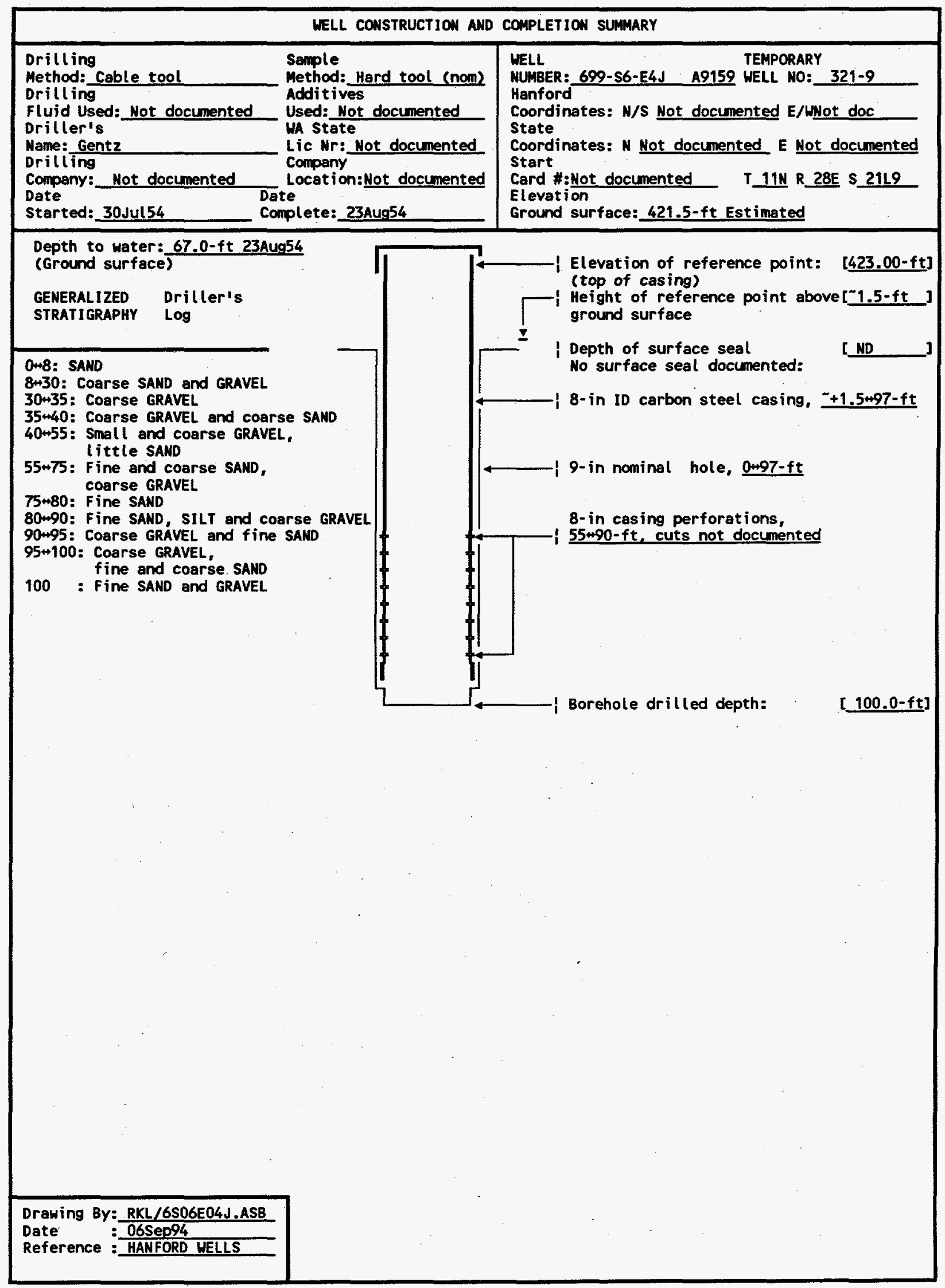




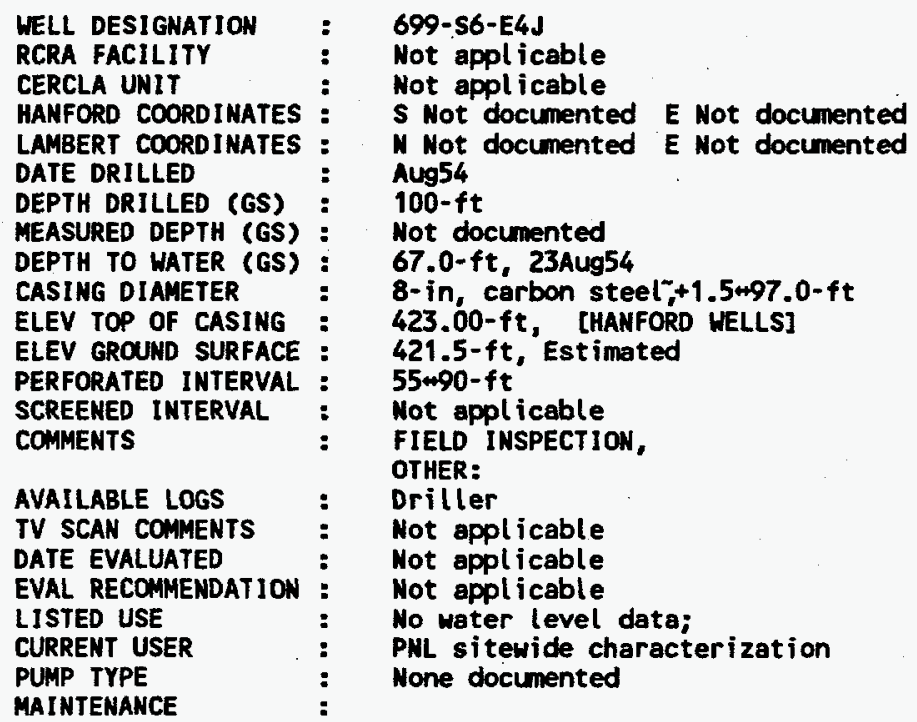


DOE/RL-94-89, Rev. 2

$01 / 96$

\section{ATTACHMENT I}

GEOLOGY AND HYDROGEOLOGY OF THE 400 AREA 
DOE/RL-94-89, Rev. 2

$01 / 96$

This page intentionally left blank. 


\section{ATTACHMENT I}

Hydrogeology of the 400 Area is summarized in Groundwater Impact Assessment Report for the 400 Area Ponds: WHC-EP-0587. The geologic strata consist of approximately 600 feet of fluvial, lacustrine and glaciofluvial sediments which overlie the Columbia River Basalt Group. These sediments are divided into the Miocene-Pliocene Ringold Formation and the Pleistocene Hanford Formation. A thin veneer of eolian silt and sand covers the area.

The Columbia River Basalt Group is approximately 600 feet below the ground surface. The uppermost basalt flow consists of an upper flow breccia and a lower hard, dense basalt. The Ringold Formation is approximately 450 feet thick. The Ringold Formation consists of interstratified clay, silt, sand, and gravel and is described in more detail in Geology and Hydrology of the Hanford Site: A Standard Text for Use in Westinghouse Hanford Company Documents and Reports, WHC-SD-ER-TI-003 and Revised Stratigraphy for the Ringold Formation, Hanford Site, South Central Washington, WHC-SD-EN-EE-004. The Hanford formation is up to 150 feet thick in the area, and consists of a sand-dominated facies, which is primarily a dense, laminated, fine to coarse sand with little silt. The near surface soils at the 400 Area are composed of very dense, laminated fine to medium sand with little silt.

The unconfined aquifer in the 400 Area is at approximately 390 feet above mean sea level. Groundwater flows generally to the east-southeast.

Included in this attachment are a soil map and description of soil. types, from the report Soil Survey Hanford Project in Benton County Washinaton: BNWL 243, April, 1966. 
"modified from

BNWL-243"

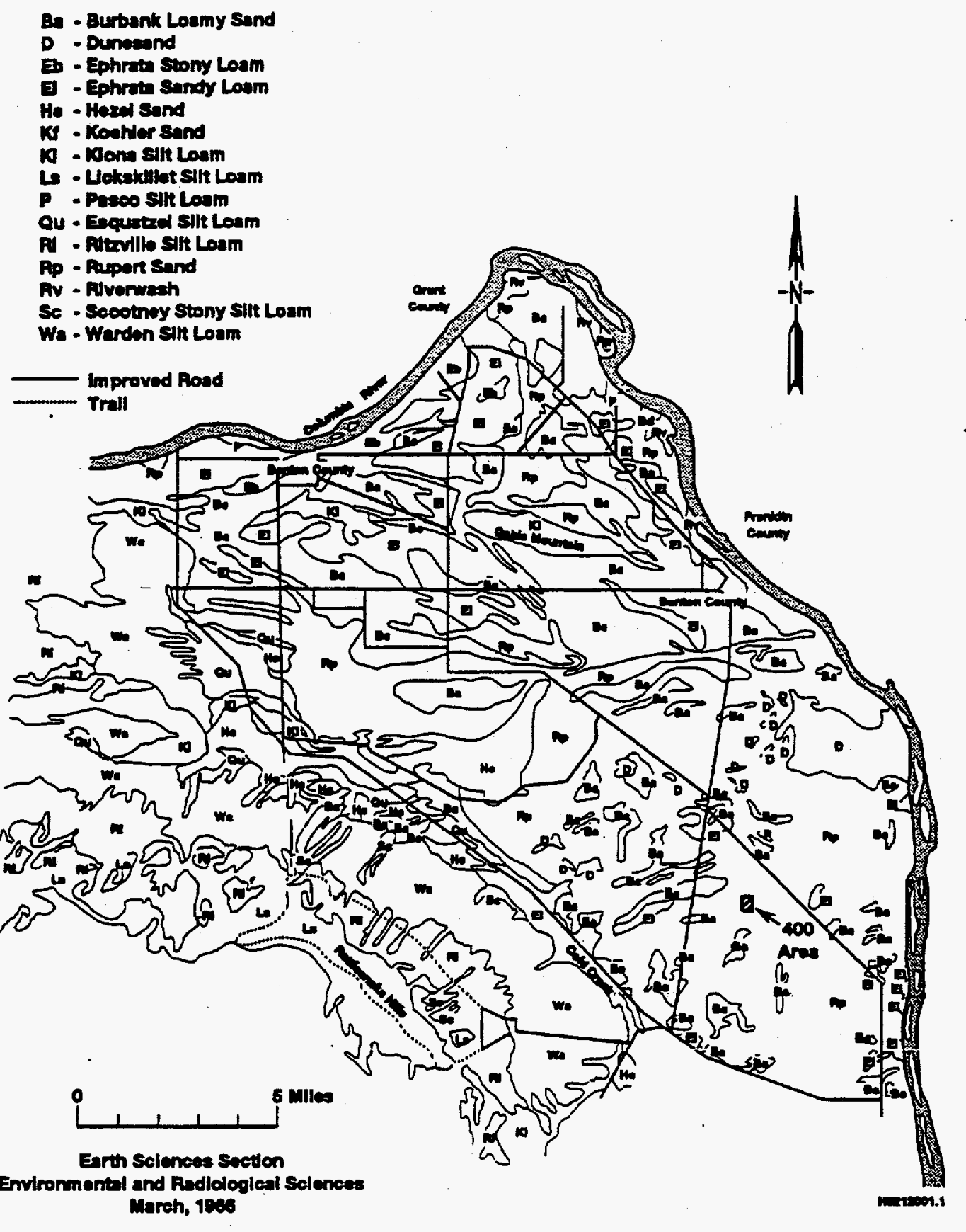


Correlation Table

\begin{tabular}{|c|c|c|c|}
\hline & Current Classification & & 1919 Soll Survey \\
\hline Symbol & Soll Type & Symbol & Soll Trpe \\
\hline $\mathbf{R i}$ & Ritzville silt loam & Rs, R, R1 & Ritzville sand, very fine sand and loam \\
\hline $\operatorname{Rp}$ & Rupert $s$ and & Ws, Hf & Winchester sand, fine sand \\
\hline Kf & Koehler sand & Kf & Koehler fine sand \\
\hline $\mathrm{Ba}$ & Burbank loamy sand & Es, Bs, Bf, Ef & Ephrata sand, Beverly fine sand, very fine sand \\
\hline He & Hezel sand & $Q f, Q s, Q t$ & Quincy sand \\
\hline E) & Ephrata sandy loam & Ef & Ephrata sandy loam, fine sandy loam \\
\hline Ls & Lickskillet silt loam & $\mathbf{s}$ & Scabland; elevation $2,000 \mathrm{ft}$. \\
\hline $\mathbf{E b}$ & Ephrata stony loam & s & Scabland glacial deposits near Columbia River \\
\hline Ki & Kiona stlt loam & S & Scabland; elevation $2,000 \mathrm{ft}$ \\
\hline Wa & Warden stlt loam & So, si, Ss & Sagemoor fine sand very fine sand, silt loam \\
\hline Sc & Scootney stony silt loam & Sf & Stacy stony silt loam \\
\hline$p$ & Pasco silt loam & $P, P c$ & Pasco fine sandy loam, clay \\
\hline Qu & Esquatzel silt loam & Ey, Eo & Esquatzel fine sandy loam, silt loam \\
\hline Rv & Riverwash & Rr & Riverwash \\
\hline D & Dune sand & D & Dune sand \\
\hline
\end{tabular}


Approximate Classification of Hanford Soils

Engineering and Higher Categories

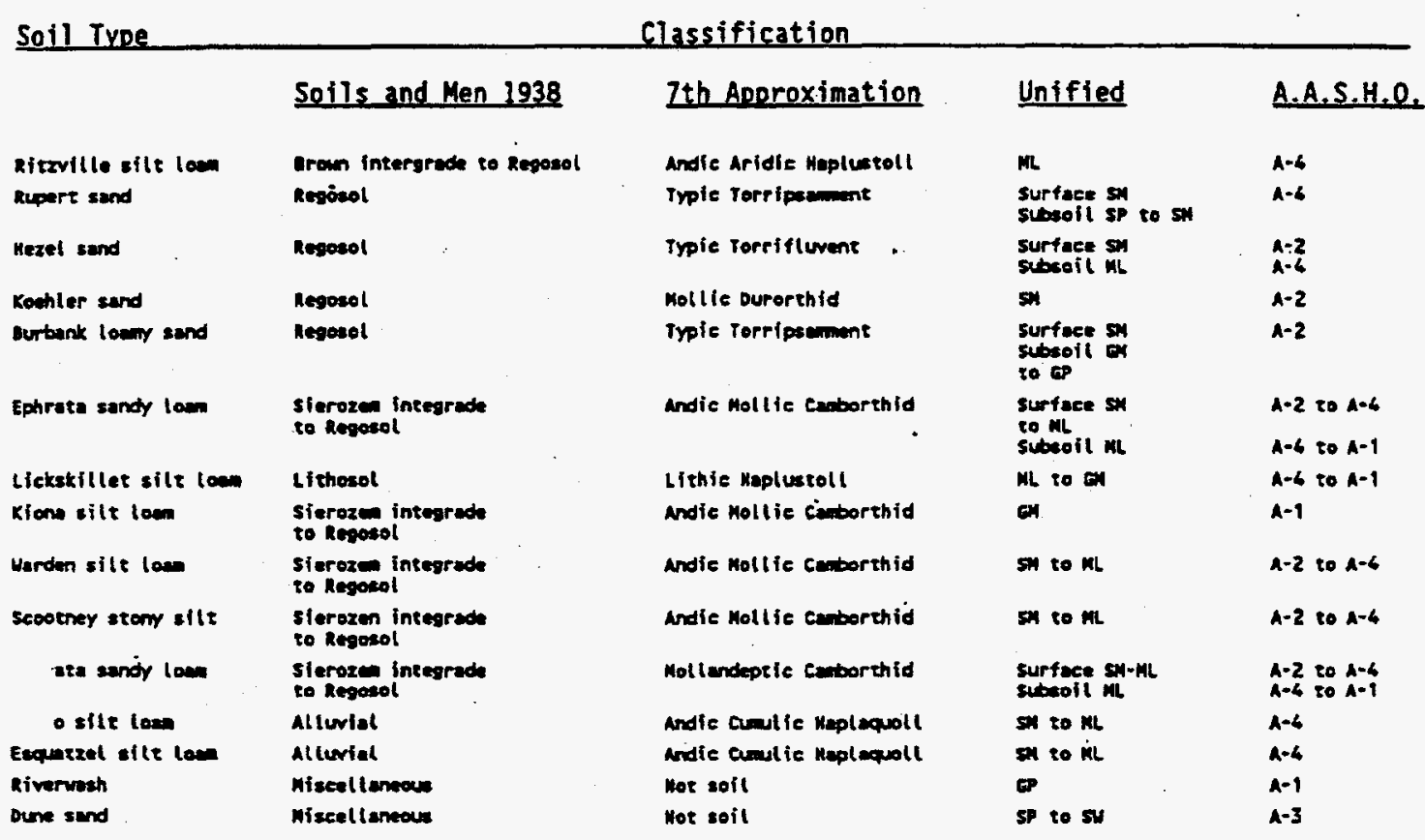




\section{Capability Classification}

Soil Trpe

Ritzville silt loam

Rupert sand

Koehler sand

Burbank loamy sand

Hezel sand

Ephrata sandy loam

Lickskillet silt loam

Ephrata stony loam

Kiona silt loan

Warden silt loam

Scootney stony silty loam

Pasco silt loam

Esquatzel silt loam

Riverwash

Dune sand
Dryland

III-VII

VII

VII

VII

VII

VI

$V I \& V I I$

VI

VI

IV

VI

IV

III

VIII

VIII

\section{Irrigated}

I-IV

IV

IV

IV

IV

II-IV

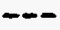

$--$

I-IV

III

I

$--$ 
DOE/RL-94-89, Rev. 2

$01 / 96$

ATTACHMENT $\mathbf{J}$

WASTE WATER INFORMATION

960126.1027

ATT $\mathbf{j}-\mathbf{i}$ 


\section{DOE/RL-94-89, Rev. 2 \\ $01 / 96$}

This page intentionally left blank. 


\section{ATTACHMENT $J$ \\ SECTION E : WASTEWATER INFORMATION}

Ortho Phosphate: Result was determined by Phosphate (P04), EPA method 300.0.

Total Phosphate : Result was determined by Phosphate as Phosphorous, EPA method 365.2 .

Nitrate-N : This result is actually Nitrate-Nitrite-N (N03-NO2-N). This determination is the total inorganic nitrogen present in the sample. Nitrate-N result is actually expected to be lower than the $\mathrm{NO3}_{-\mathrm{NO}} \mathrm{N}$ - result provided.

TKN-N : This result was estimated by adding Ammonia as $N$ with N03-NO2-N. Since TKN is a measure of all nitrogen present in the sample, this estimate is a close approximation to the actual result. This estimate was used because current labs on contract do not perform TKN-N.

Ammonia-N : This result is truly Ammonia-N EPA method 350.1.

Please note the following units:

$\mathrm{mg} / 1$ is $\mathrm{ppm}$

$u g / 1$ is $\mathrm{ppb}$ 
DOE/RL-94-89, Rev. 2
$01 / 96$

\section{ATTACHMENT $K$}

\section{REFERENCES AND METRIC CONVERSION CHART}


DOE/RL-94-89, Rev. 2
$01 / 96$

This page intentionally left blank. 


\section{ATTACHMENT $K$}

\section{REFERENCES}

Bechte1, 1971a, Final Geology Report for the Fast Flux Test Facility, BR-5853-C-005, Bechtel Power Corporation, San Francisco, CA.

Bechte1, 1971b, Final Soil Investigation Report for the Fast Flux Test Facility, Richland, Washington, for the United States Atomic Energy Commission, HEDL-BC-6041, Bechtel Power Corporation, San Francisco, CA.

B7ume \& Associates, 1970, Seismic and Geologic Siting Evaluation, Fast Flux Test Facility near Richland, Washington, JABE-WADCO-01, John A. Blume \& Associates, San Francisco, CA.

Delaney, C.D., K.A. Lindsey, and S.P. Reidel, 1991, Geology and Hydrology of the Hanford Site: A Standard Text for Use in West inghouse Hanford Company Documents and Reports, WHC-SD-ER-TI-003, Westinghouse Hanford Company, Richland, WA.

Hajek, B.F., April, 1966, Soil Survey Hanford Project in Benton County Washington, BNWL-243, Battelle Northwest Laboratory, Rich7and, WA.

HEDL-400, December, 1980, A Summary Description of the Fast Flux Test Facility, Hanford Engineering Development Laboratory, Richland, WA.

Lindsey, K.A., 1991, Revised Stratigraphy for the Ringold Formation, Hanford Site, South Central Washington, WHC-SD-EN-EE-004, Westinghouse Hanford Company, Richland, WA.

WHC, 1990, 400 Area Secondary Cooling Water Stream-Specific Report, WHC-DP-0342, Addendum 28, Westinghouse Hanford Company, Richland, WA.

WHC, 1991, Groundwater Maps of the Hanford Site, June 1991, WHC-EP-0394-3, Westinghouse Hanford Company, Richland, WA.

WHC, 1992a, Groundwater Impact Assessment Report for the 400 Area Ponds, WHC-EP-0587, Westinghouse Hanford Company, Richland, WA.

WHC, 1992b, Project W-252, Phase II Liquid Effluent Engineering Report, WHC-SD-W252-ER-001, Rev. 0, Westinghouse Hanford Company, Rich1and, WA.

WHC, 1995, 400 Area Secondary Cooling Water Sampling and Analysis Plan, WHC-SD-FF-PLN-002, Westinghouse Hanford Company, Richland, WA. 


\section{METRIC CONVERSION CHART}

The following conversion chart is provided to the reader as a tool to aid in conversion.
Into metric units
Out of metric units

\begin{tabular}{|c|c|c|c|c|c|}
\hline If you know & $\begin{array}{c}\text { Multiply } \\
\text { by }\end{array}$ & To get & If you know & $\begin{array}{c}\text { Multiply } \\
\text { by }\end{array}$ & To get \\
\hline \multicolumn{3}{|c|}{ Length } & \multicolumn{3}{|c|}{ Length } \\
\hline inches & 25.40 & millimeters & millimeters & 0.0393 & inches \\
\hline inches & 2.54 & centimeters & centimeters & 0.393 & inches \\
\hline feet & 0.3048 & meters & meters & 3.2808 & feet \\
\hline yards & 0.914 & meters & meters & 1.09 & yards \\
\hline miles & 1.609 & kilometers & kilometers & 0.62 & miles \\
\hline \multicolumn{3}{|c|}{ Area } & \multicolumn{3}{|c|}{ Area } \\
\hline $\begin{array}{l}\text { square } \\
\text { inches }\end{array}$ & 6.4516 & $\begin{array}{l}\text { square } \\
\text { centimeters }\end{array}$ & $\begin{array}{l}\text { square } \\
\text { centimeters }\end{array}$ & 0.155 & $\begin{array}{l}\text { square } \\
\text { inches }\end{array}$ \\
\hline square feet & 0.092 & $\begin{array}{l}\text { square } \\
\text { meters }\end{array}$ & $\begin{array}{l}\text { square } \\
\text { meters }\end{array}$ & 10.7639 & $\begin{array}{l}\text { square } \\
\text { feet }\end{array}$ \\
\hline $\begin{array}{l}\text { square } \\
\text { yards }\end{array}$ & 0.836 & $\begin{array}{l}\text { square } \\
\text { meters }\end{array}$ & $\begin{array}{l}\text { square } \\
\text { meters }\end{array}$ & 1.20 & $\begin{array}{l}\text { square } \\
\text { yards }\end{array}$ \\
\hline $\begin{array}{l}\text { square } \\
\text { miles }\end{array}$ & 2.59 & $\begin{array}{l}\text { square } \\
\text { kilometers }\end{array}$ & $\begin{array}{l}\text { square } \\
\text { kilometers }\end{array}$ & 0.39 & $\begin{array}{l}\text { square } \\
\text { miles }\end{array}$ \\
\hline $\begin{array}{l}\text { square } \\
\text { miles }\end{array}$ & 259 & hectares & hectares & 0.00391 & $\begin{array}{l}\text { square } \\
\text { miles }\end{array}$ \\
\hline acres & 0.404 & hectares & hectares & 2.471 & acres \\
\hline \multicolumn{3}{|c|}{ Mass (weight) } & \multicolumn{3}{|c|}{ Mass (weight) } \\
\hline ounces & 28.35 & grams & grams & 0.0352 & ounces \\
\hline pounds & 0.453 & kilograms & kilograms & 2.2046 & pounds \\
\hline short ton & 0.907 & metric ton & metric ton & 1.10 & short ton \\
\hline \multicolumn{3}{|c|}{ Volume } & \multicolumn{3}{|c|}{ Volume } \\
\hline $\begin{array}{l}\text { fluid } \\
\text { ounces }\end{array}$ & 29.57 & milliliters & milliliters & 0.03 & $\begin{array}{l}\text { fluid } \\
\text { ounces }\end{array}$ \\
\hline quarts & 0.95 & Titers & liters & 1.057 & quarts \\
\hline gallons & 3.79 & Titers & liters & 0.26 & gallons \\
\hline cubic feet & 0.03 & $\begin{array}{l}\text { cubic } \\
\text { meters }\end{array}$ & $\begin{array}{l}\text { cubic } \\
\text { meters }\end{array}$ & 35.3147 & cubic feet \\
\hline cubic yards & 0.76 & $\begin{array}{l}\text { cubic } \\
\text { meters }\end{array}$ & $\begin{array}{l}\text { cubic } \\
\text { meters }\end{array}$ & 1.308 & $\begin{array}{l}\text { cubic } \\
\text { yards }\end{array}$ \\
\hline \multicolumn{3}{|c|}{ Temperature } & \multicolumn{3}{|c|}{ Temperature } \\
\hline Fahrenheit. & $\begin{array}{l}\text { subtract } \\
32 \text { then } \\
\text { multiply } \\
\text { by } 5 / 9 \text { ths }\end{array}$ & Celsius & Celsius & $\begin{array}{l}\text { multiply } \\
\text { by } \\
9 / 5 \text { ths, } \\
\text { then add } \\
32\end{array}$ & Fahrenheit \\
\hline
\end{tabular}

Source: Engineering Unit Conversions, M. R. Lindeburg, PE., Second Ed., 1990, Professional Publications, Inc., Belmont, California. 


\section{DISTRIBUTION}

OFFSITE

MSIN

Washington State Department of Ecology Kennewick, WA

Greta B. Davis

B5-18

Melodie A. Selby (2)

B5-18

U.S. Environmental Protection Agency

Region 10

Richland, WA

Doug Sherwood

J. Wilkinson

Confederated Tribes of the Umatilla

Indian Nation

P. 0. Box 638

Pendleton, Oregon 97801

D. Powaukee

Nez Perce Tribe

P. 0. Box 365

Lapwai, Idaho 93540

R. Jim, Manager

Environmental Restoration/ Waste Management Program

Yakama Indian Nation

P. 0. Box 151

Toppenish, Washington 98948

ONSITE

U.S. Department of Energy,

Richland Operations office

D. H. Chapin

A5-15

0. A. Farabee

N2-36

R. N. Kreke1

N2-36

J. E. Mecca

R3-79

OSTI (2)

Reading Room (2)

E6-44

$\mathrm{H} 2-53$

Distr-1 


\section{DISTRIBUTION (cont)}

ONSITE

Pacific Northwest National Laboratory

MSIN

Technical Library

$\mathrm{K} 1-11$

Westinghouse Hanford Company

B. P. Atencio

H6-25

F. J. Carvo

$\mathrm{N} 1-41$

K. J. Leuck

S6-71

J. J. Luke

N. M. Menard (5)

$\mathrm{H} 6-25$

P. C. Miller

H6-25

Central Files

N2-57

EDMC/AR

A3-88

H6-08 